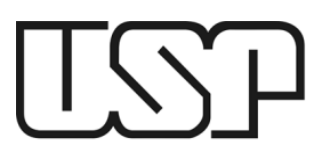

UNIVERSIDADE DE SÃO PAULO

FACULDADE DE ZOOTECNIA E ENGENHARIA DE ALIMENTOS

FERNANDA CAVALLARI DE CASTRO

Silenciamento gênico do BMPRII em células da granulosa bovinas 


\title{
Silenciamento gênico do BMPRII em células da
}

\author{
granulosa bovinas
}

Dissertação apresentada à Faculdade de

Zootecnia e Engenharia de Alimentos da

Universidade de São Paulo, como parte dos requisitos para a obtenção do Título de Mestre em Zootecnia.

Área de Concentração: Qualidade e Produtividade Animal.

Orientador: Prof ${ }^{a}$. Dr ${ }^{a}$. Cláudia Lima Verde Leal.

Pirassununga - SP 
Dados Internacionais de Catalogação na Publicação

Serviço de Biblioteca e Informação da Faculdade de Zootecnia e Engenharia de Alimentos da Universidade de São Paulo

\begin{tabular}{|c|} 
\\
Castro, Fernanda Cavallari de \\
C355s $\quad$ Silenciamento gênico do BMPRII em células da \\
granulosa bovinas / Fernanda Cavallari de Castro. -- \\
Pirassununga, 2014. \\
Dissertação (Mestrado) -- Faculdade de Zootecnia e \\
Engenharia de Alimentos - Universidade de São Paulo. \\
Departamento de Medicina Veterinária.
\end{tabular}


Epígrafe

"Agradeço todas as dificuldades que enfrentei; não fosse por elas, eu não teria saído do lugar. As facilidades nos impedem de caminhar. Mesmo as críticas nos auxiliam muito."

"Chico Xavier"

"Sonhos determinam o que você quer. Ação determina o que você conquista”.

"Aldo Novak" 


\section{Dedico:}

À minha orientadora, Cláudia, que sempre me apoiou diante das dificuldades, me incentivou, me socorreu nas horas de angústia $e$ apuro, me disse para parar quando necessário ou mesmo para ir em frente em minhas criações, me deu base e sustentação para sempre prosseguir da melhor forma $e$, principalmente, esteve ao meu lado não apenas como minha orientadora, mas também como uma grande amiga.

Muito obrigada pelo apoio,
compreensão, paciência, conselhos e,
principalmente, por confiar em mim.

Aos meus pais, Dirce e Antônio e ao meu namorado, Leandro, que sempre estiveram ao meu lado me apoiando, incentivando, aconselhando e, principalmente, me fortalecendo para continuar e vencer os vários obstáculos encontrados durante meu Mestrado.

Muito obrigada pelo amor incondicional, carinho, incansável apoio, pela paciência e por todos os esforços e concessões que fizeram para que eu chegasse até aqui. Amo demais vocês. 


\section{AGRADECIMENTOS}

À Fundação de Amparo a Pesquisa do Estado de São Paulo (FAPESP), pelo apoio financeiro destinado à realização desta pesquisa.

Ao CNPq, pela concessão da bolsa de Mestrado e confiança depositada.

À minha orientadora Prof. ${ }^{a}$ Dr. ${ }^{a}$ Cláudia Lima Verde Leal que, pelo enorme apoio, dedicação, compreensão, confiança, ensinamentos, contribuição para meu crescimento científico e intelectual e, sobretudo, pela amizade concedida.

A todos os integrantes do Laboratório de Histologia Animal do Departamento de Medicina Veterinária na Faculdade de Zootecnia e Engenharia de Alimentos (FZEA) da Universidade de São Paulo, Campus de Pirassununga, em especial aos alunos de Mestrado Hugo Fernandes e Maria Carolina Rodrigues Veleriano da Cunha, de Doutorado, Maria Helena Cruz e de Pós-Doutorado Lígia Garcia Mesquita e Kátia Lancellotti Schwarz, pela grande parceria, apoio incondicional, dedicação, compreensão, por todos os momentos agradáveis proporcionados e, sobretudo, pela amizade concedida.

Aos alunos de Doutorado Rodrigo da Silva Nunes Barreto e de Pós-Doutorado Fabiana Fernandes Bressan, da Faculdade de Zootecnia e Engenharia de Alimentos da Universidade de São Paulo, Campus de Pirassununga/SP, pelo apoio e disponibilidade oferecida.

À Márcia Ramos Monteiro da Silva, Técnica Especialista do Laboratório de Morfofisiologia Molecular do Desenvolvimento (LMMD), da Faculdade de Zootecnia e Engenharia de Alimentos da Universidade de São Paulo, Campus de Pirassununga/SP, pelo enorme apoio, ajuda e amizade concedida. 
Aos Profs. Dr. Flávio Vieira Meirelles e Dr. Heidge Fukumasu e suas competentes equipes, responsáveis pelo Laboratório de Morfofisiologia Molecular do Desenvolvimento (LMMD), da Faculdade de Zootecnia e Engenharia de Alimentos da Universidade de São Paulo, Campus de Pirassununga/SP, pela enorme colaboração e gentileza em fornecer alguns equipamentos indispensáveis para o desenvolvimento do presente projeto.

À Faculdade de Zootecnia e Engenharia de Alimentos de São Paulo, pela oportunidade de realização do curso de Mestrado e disponibilização dos laboratórios.

Aos frigoríficos Barra Mansa e Olhos D’Água, pela contribuição no fornecimento dos ovários de fêmeas bovinas, utilizados pra o desenvolvimento dos presentes experimentos.

Ao Hospital Veterinário da Faculdade de Medicina Veterinária e Zootecnia da Universidade de São Paulo, Campus de Pirassununga/SP, em especial ao João Batista da Silva, responsável pelo setor de Radiologia, pela enorme colaboração e gentileza em possibilitar a revelação dos filmes radiográficos durante a execução da técnica de Western Blotting.

E a todos que direta ou indiretamente contribuíram para o desenvolvimento deste Mestrado, muito obrigada. 


\section{RESUMO}

CASTRO, F. C. Silenciamento gênico do BMPRII em células da granulosa bovinas. 2014. 157f. Dissertação (Mestrado) - Faculdade de Zootecnia e Engenharia de Alimentos, Universidade de São Paulo, Pirassununga, 2014.

As células da granulosa (CG) são constituintes do ambiente folicular de suma importância para o desenvolvimento, maturação e aquisição da competência oocitária, desempenhando funções como a esteroidogênese, expressão de receptores de LH (LHR) e síntese de inúmeras proteínas essenciais. Contudo, a funcionalidade e ação destas células são dependentes de alguns fatores derivados do oócito, como o GDF9 e o BMP15. A ação desses fatores, por sua vez, depende da sinalização via receptor BMPRII, já identificado em células da granulosa de mamíferos, porém com suas funções ainda pouco conhecidas na espécie bovina. O silenciamento gênico por lipofecção consiste num método de transfecção eficiente e pouco agressivo para as células, representando uma importante ferramenta para o estudo funcional de genes e proteínas celulares. O objetivo do presente trabalho foi, primeiramente, otimizar as condições de lipofecção em CG bovinas e, a partir desse protocolo, estabelecer uma metodologia de silenciamento gênico para o BMPRII usando a técnica de RNA de interferência, a fim de possibilitar a futura utilização de tal estratégia como ferramenta para o estudo funcional do BMPRII e outros genes de interesse. Para tanto, no primeiro experimento referente à otimização das condições de lipofecção em CG bovinas, onde as células da granulosa, obtidas de ovários oriundos de abatedouro foram tratadas com diferentes quantidades dos lipofectores Lipofectamine $^{\circledR}$ RNAiMAX $(1,2$ e $3 \mu \mathrm{l})$ ou Lipofectamine $^{\mathrm{TM}} 2000(1,2$ e $3 \mu \mathrm{l})$ e dos indicadores de transfecção siGLO $^{\circledR}(30,50,75$ e $100 \mathrm{nM})$ ou plasmídeo transgênico FUGW (100, 200, 300, 400, 600 e $900 \mathrm{nM})$ durante 24 e 48 horas de cultivo. A melhor

eficiência de lipofecção foi observada às 24 horas de cultivo com $2 \mu 1$ de Lipofectamine $^{\mathrm{TM}}$ $2000+100 \mathrm{nM}$ de siGLO $^{\circledR}$. Num segundo experimento, a partir das condições de lipofecção determinadas, foram testadas diferentes concentrações do siBMPRII ( 0 a 500 pmol) durante $24 \mathrm{~h}$ de cultivo. Ao final desse período, as células de cada grupo foram avaliadas quanto à abundância relativa mRNA BMPRII por PCR em tempo real. Todas as concentrações resultaram em uma redução semelhante de transcritos, sendo possível adotar a menor concentração $(100 \mathrm{pM})$, a qual foi utilizada para determinar o tempo 
mínimo de cultivo necessário para obter eficiência no processo de silenciamento. As células foram tratadas por $0,6,12,18$ e 24 h e também avaliadas quanto aos transcritos de BMPRII. Os tempos de incubação que proporcionaram maior redução do mRNA para o BMPRII foram 18 e 24 horas. A melhor concentração e tempo de incubação com o siRNA foram avaliados por Western Blotting, confirmando a redução da expressão de BMPRII também em nível de proteína. Em conclusão, este trabalho possibilitou o estabelecimento de uma metodologia eficiente para o silenciamento gênico por lipofecção do BMPRII em CG bovinas, a qual poderá ser utilizada como ferramenta para o estudo funcional de diversos genes de interesse.

Palavras-chave: siRNA; lipofecção; GDF9; BMP15; Knockdown; 


\begin{abstract}
CASTRO, F. C. Gene silencing of BMPRII in bovine granulosa cells. 2014. $157 \mathrm{f}$. M. Sc. Dissertation - Faculdade de Zootecnia e Engenharia de Alimentos, Universidade de São Paulo, Pirassununga, 2014.
\end{abstract}

Granulosa cells (GC) are part of the folicular environment and are important for the development, maturation and acquisition of developmental competence of oocytes, performing functions such as steriodogenesis, expression of LH receptors (LHR) and synthesis of several important proteins. The function of these cells is dependent on some oocyte-derived factors, such as GDF9 and BMP15. Signaling of these factors involves the activation of the BMPRII receptor identified in granulosa cells, however, its function is not well established in bovine cells. Gene silencing is an important tool for functional studies of different cellular proteins. The aim of the present study was to develop a protocol for gene silencing using the RNA interference technique by lipofecction to knockdown BMPRII expression, for future functional studies on the role of this receptor and other genes of interest in bovine granulosa cells. For this purpose, the first experimente aimed to optimize lipofection conditions in bovine granulosa cells, collected from abbattoir ovaries and cultured in vitro. Lipofecction was tested for different concentrations of two diferent lipofection agents (1, 2 and $3 \mu$ l Lipofectamine $®$ RNAiMAX or Lipofectamine $\left.{ }^{\mathrm{TM}} 2000\right)$ and two transfection indicators $(30,50,75$ and 100nM siGLO® or 100, 200, 300, 400, 600 and $900 \mathrm{nM}$ transgenic plsamid FUGW) for 24 and $48 \mathrm{~h}$ in culture. Best lipofection efficiency was observed at $24 \mathrm{~h}$ culture with $2 \mu \mathrm{l}$ Lipofectamine $^{\mathrm{TM}} 2000+100 \mathrm{nM}$ siGLO ${ }$, which was used for the next experiment. The second experiment tested different BMPRII-siRNA concentrations (0 to $500 \mathrm{pM}$ ) for 24 h. At the end of culture the cells were be assessed for the relative abundance for BMPRII by real time PCR. All concentrations similarly reduced transcript abundance relative to control $(0 \mathrm{pM})$. For the third experiment, the lowest effective concentration was used $(100 \mathrm{pM})$ to test different culture periods with the BMPRII-siRNA and determine the minimum period to obtain transcript reduction. Cells will be treated for 0, 6, 12, 18 and $24 \mathrm{~h}$ and assessed for BMPRII transcripts. Greater reduction in BMPRII transcripts was observed after 18 and $24 \mathrm{~h}$. The best concentration $(100 \mathrm{pM})$ and time $(24 \mathrm{~h})$ were confirmed for knockdown of the BMPRII protein by western blotting. In conclusion, this 
work has provided the establishment of a reliable method for gene silencing using lipofection for the BMPRII in bovine granulosa cells, which may be used for functional studies for this gene and others of interest.

Keywords: siRNA; lipofection; GDF9; BMP15; Knockdown. 


\section{LISTA DE FIGURAS}

Página

Figura 1. Figura 1. Representação esquemática do desenvolvimento folicular 12 até a ovulação no interior do ovário mamífero.

Figura 2.

Aspectos morfológicos dos diferentes estágios do desenvolvimento folicular

Figura 3. Comunicação celular entre o oócito e as células do cumulus, essencial para o crescimento normal e desenvolvimento tanto do oócito quanto do folículo. A) A comunicação ocorre através de sinalização parácrina (setas rosa) e de trocas por junções gap de pequenas moléculas reguladoras (seta azul). Este é um eixo de comunicação bidirecional entre o oócito e as células do cumulus. B) Projeções transzonais (TZP) a partir de células do cumulus, que atravessam a zona pelúcida e formam junções intercelulares do tipo gap no interior de invaginações profundas na superfície do oócito. TZPs podem ser ricas em F-actina (A-TZP), ou compostos principalmente de microtúbulos (M-TZP).

Figura 4. Representação esquemática da sinalização parácrina entre o oócito e as células da granulosa circundantes. Estão representadas as vias de sinalização dos fatores BMP15 e GDF9, derivados do oócito.

Figura 5. Mecanismo de silenciamento gênico induzido por RNA de interferência. O RNAi pode ser introduzido na célula por transfecção de siRNA ou por vetores (virais ou plasmidiais).

Figura 6. Representação esquemática da obtenção, processamento e cultivo das células da granulosa bovinas anteriormente à submissão das mesmas aos tratamentos do experimento 1 e 2 .

Figura 7. Figura 7. Fotomicrografia de luz (200X) de diferentes densidades celulares (CG) em placas Petri: 50.000 (A), 100.000 (B) e 200.000 células $(\mathrm{C})$.

Figura 9. Fotomicrografia de luz $(400 \mathrm{X})$ de diferentes densidades celulares (CG) em placas Nunc de 4 poços: 30.000 (A) e 50.000 células (B). 
Figura 10. Fotomicrografia de luz (400X) de cultivos de CG na ausência (A) e na presença (B) do antibiótico ciprofloxacina $(50 \mathrm{ng} / \mathrm{mL})$.

Figura 11. Figura 10. Fotomicrografias de luz (200X) de diferentes períodos de 46 cultivo de CG: 24 horas (A), 48 horas (B), 72 horas (C) e 96 horas (D).

Figura 12. Representação esquemática do procedimento de lipofecção em cultivo primário de CG bovinas.

Figura 13. Figura 13. Fotomicrografias (400X) de luz normal (A e C) e de fluorescência (B e D) de CG submetidas à lipofecção com o agente lipofector Lipofectamina RNAiMAX e o marcador Plasmídeo FUGW. Estão representadas apenas as concentrações que proporcionaram fluorescência: $2 \mu \mathrm{L}$ de Lipofectamina RNAiMAX e 600 nM do FUGW (A e B); $2 \mu \mathrm{L}$ de Lipofectamina RNAiMAX e 900 nM do FUGW (C e D).

Figura 14. Figura 14. Fotomicrografias (400X) de luz normal (A, C e E) e de fluorescência (B, D e F) de CG submetidas à lipofecção com o agente lipofector Lipofectamine ${ }^{\circledR}$ RNAiMAX e o marcador siGLO®. Estão representadas apenas as concentrações que proporcionaram fluorescência: $2 \mu \mathrm{L}$ de Lipofectamine ${ }^{\circledR}$ RNAiMAX e $50 \mathrm{nM}$ do siGLO® $\left(A\right.$ e B); $2 \mu \mathrm{L}$ de Lipofectamine ${ }^{\circledR}$ RNAiMAX e $75 \mathrm{nM}$ do siGLO ${ }^{\circledR}\left(\mathrm{C}\right.$ e D); $2 \mu \mathrm{L}$ de Lipofectamine ${ }^{\circledR}$ RNAiMAX e $100 \mathrm{nM}$ do SiGLO® (E e F).

Figura 15. Valores médios de pixels medidos pelo programa computacional ImageJ ${ }^{\circledR}$ para os grupos de CG submetidas à exposição de $2 \mu \mathrm{L}$ Lipofectamine ${ }^{\circledR}$ RNAiMAX + 600 e 900 nM do plasmídeo transgênico FUGW ou 50, 75 e 100 nM do marcador comercial siGLO. Os dados são apresentados como média ( \pm EPM) e as letras iguais representam a ausência de diferença significativa $(\mathrm{p}>0,05)$.

Figura 16. Fotomicrografias (400X) de luz normal (A, C e E) e de fluorescência $(\mathrm{B}, \mathrm{D}$ e $\mathrm{F})$ de $\mathrm{CG}$ submetidas à lipofecção com o agente lipofector LipofectaminaTM 2000 e o marcador plasmídeo FUGW. Estão representadas apenas as concentrações que proporcionaram fluorescência celular: $2 \mu \mathrm{L}$ de LipofectamineTM $2000+300 \mathrm{nM}$ do 
FUGW (A e B); $2 \mu \mathrm{L}$ de LipofectamineTM + 60 0nM do FUGW (C e D); $2 \mu \mathrm{L}$ de LipofectamineTM $2000+900$ nM do FUGW (E e F).

Figura 17. Fotomicrografias (400X) de luz normal (A e C) e de fluorescência (B

e D) de CG submetidas à lipofecção com o agente lipofector LipofectaminaTM 2000 e o marcador siGLO®. Estão representadas as seguintes concentrações: $2 \mu \mathrm{L}$ de LipofectamineTM $2000+30 \mathrm{nM}$ de $\operatorname{siGLO}{ }^{\circledR}(\mathrm{A}$ e B); $2 \mu \mathrm{L}$ de LipofectamineTM $2000+50 \mathrm{nM}$ de SiGLO® (C e D).

Figura 18. Fotomicrografias (400X) de luz normal (A e C) e de fluorescência (B

e D) de CG submetidas à lipofecção com o agente lipofector LipofectaminaTM 2000e o marcador siGLO®. Estão representadas as seguintes concentrações: $2 \mu \mathrm{L}$ de LipofectamineTM $2000+75$ nM de siGLO® (A e B); $2 \mu \mathrm{L}$ de LipofectamineTM $2000+100 \mathrm{nM}$ de $\operatorname{siGLO}{ }^{\circledR}(\mathrm{C}$ e D).

Figura 19. Figura 19. Valores médios de pixels medidos pelo programa computacional ImageJ ${ }^{\circledR}$ para os grupos de CG submetidas à exposição de $2 \mu \mathrm{L}$ LipofectamineTM 2000 + 300, 600 e 900 nM do plasmídeo transgênico FUGW ou 30, 50, 75 e 100 nM do marcador comercial siGLO, assim como grupo controle de CG não exposto às drogas e em meio de cultivo convencional (DMEM com aditivos). Os dados são apresentados como média $( \pm$ EPM) e as letras diferentes representam diferença significativa $(\mathrm{p}<0,05)$.

Figura 20. Representação esquemática do procedimento de lipofecção em cultivo primário de CG bovinas.

Figura 21. Representação esquemática do Experimento 2.

Figura 22. Eficiências de amplificação. Em A, B e C estão representadas as 96 eficiências individuais para os genes $\beta$-Actina (99,47\%), PPIA (90\%) e BMPRII $(93,4 \%)$. Em D encontra-se representado a eficiência conjunta para os três genes $(90 \%)$.

Figura 23 Valores médios de expressão gênica do BMPRII, determinados por $2 \Delta \Delta \mathrm{CT}$, referentes aos diferentes aos grupos de $\mathrm{CG}$ submetido à diferentes períodos de cultivo in vitro $(0,6,12,18$ e 24 h) em meio convencional (DMEM com aditivos). Os dados são apresentados 
como média $( \pm \mathrm{EP})$ e as letras iguais representam a ausência de diferença significativa entre os diferentes períodos $(p>0,05)$.

Figura 24. Valores médios de expressão gênica do BMPRII, determinados por $2 \Delta \Delta \mathrm{CT}$, referentes aos diferentes grupos controle de CG. Os dados são apresentados como média $( \pm \mathrm{EP})$ e as letras iguais representam a ausência de diferença significativa entre os grupos 0pM, DMEM sem aditivos e DMEM completo ( $\mathrm{p}>0,05)$.

Figura 25. Valores médios de expressão gênica do BMPRII, determinados por 2 $\Delta \Delta \mathrm{CT}$, referentes aos grupos de $\mathrm{CG}$ submetidos à diferentes concentrações do siBMRII $(0,100,200$,

Figura 26. Valores médios de expressão gênica do BMPRII, determinados por 2 103 $\Delta \Delta \mathrm{CT}$, referentes aos grupos de $\mathrm{CG}$ submetidos à diferentes períodos de incubação $(0,6,12,18$ e 24 horas) com 100 pM de siBMPRII. Os dados são apresentados como média $( \pm \mathrm{EP})$ e as letras diferentes representam diferença estatística significativa entre os grupos experimentais e o controle $(0 \mathrm{~h})(\mathrm{p}<0,05)$.

Figura 27 Imagem representativa da detecção das proteínas por western blotting 104 de três repetições do experimento de silenciamento gênico. Estão representados três grupos de CG expostos à 100 pM de siBMPRII (colunas 1,3 e 5) e três grupos expostos a 0 pM (linhas 2, 4 e 6), cultivados por um período de 24 horas.

Figura 28. Valores médios de densitometria das bandas, referentes aos grupos de CG submetidos às melhores condições de silenciamento gênico (100 pM de siBMPRII por 24 horas) e ao controle. Os dados são apresentados como média $( \pm \mathrm{EPM})$ e as letras diferentes representam diferença estatística significativa entre o grupo experimental e grupo controle $(0 \mathrm{pM})(\mathrm{p}<0,001)$. 


\section{LISTA DE TABELAS}

Página

Tabela 1. Médias das quantidades de pixels captados a partir das fotomicrografias, referentes aos diferentes grupos experimentais de CG expostos a $2 \mu 1$ do reagente Lipofectamine RNAiMAX, com seus respectivos desvios padrões.

Tabela 2. Tabela 2. Médias das quantidades de pixels captados a partir das fotomicrografias, referentes aos diferentes grupos experimentais de CG expostos à $2 \mu 1$ do reagente LipofectamineTM 2000 com seus respectivos desvios padrões.

Tabela 3. Sequências nucleotídicas do siRNA para o gene BMPRII.

Tabela 4. Sequência dos oligonucleotídeos iniciadores utilizados para a quantificação relativa dos genes PPIA, $\beta$-Actina e BMPRII.

Tabela 5. Médias $( \pm \mathrm{EP})$ de expressão gênica $(2 \Delta \Delta \mathrm{CT})$ do BMPRII referentes aos diferentes grupos controle de CG, determinadas por PCR em tempo real.

Tabela 6. Médias ( $\pm \mathrm{EP})$ de expressão gênica $(2 \Delta \Delta \mathrm{CT})$ do BMPRII, referentes aos 101 grupos de CG submetidos à diferentes concentrações do siBMPRII (0, 100, 200, 300, 400, 400 e 500pM), determinadas por PCR em tempo real.

Tabela 7. Médias ( $( \pm \mathrm{EP})$ de expressão gênica $(2 \Delta \Delta \mathrm{CT})$ do BMPRII, referentes aos grupos de CG submetidos à incubação de 100pM de siBMPRII por diferentes períodos $(0,6,12,18$ e 24 horas $)$, determinadas por PCR em tempo real.

Tabela 8. Médias $( \pm \mathrm{EPM})$ de densitometria das bandas de proteínas detectadas por western blotting, referentes aos grupos de CG submetidos às melhores condições de silenciamento (100 pM de siBMPRII por 24 horas) e ao grupo controle ( $0 \mathrm{pM}$ de siBMPRII por 24 horas). 


\section{SUMÁRIO}

Página

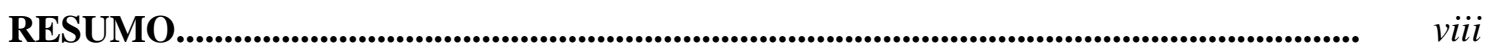

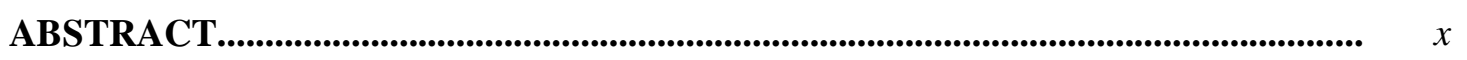

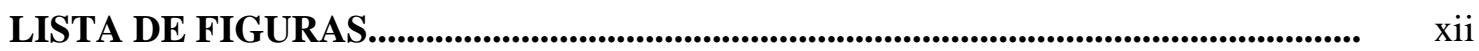

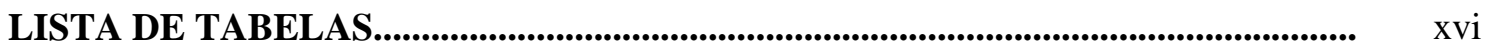

CAPÍTULO I. INTRODUÇÃO................................................................................ 1

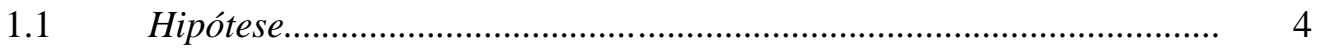

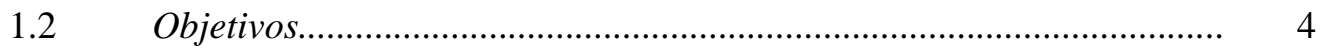

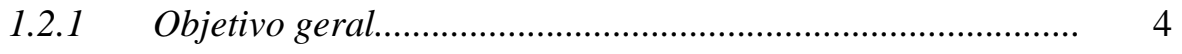

1.2.2 Objetivos específicos......................................................... 5

CAPÍTULO II. REVISÃO DE LITERATURA.............................................................. 6

2.1. O ovário mamífero................................................................................ 7

2.2. Desenvolvimento folicular: aspectos morfológicos e cronologia da formação folicular.............................................................................. 7

2.3. Interação entre o oócito, células do cumulus e células da granulosa ... $\quad 14$

2.4. Aquisição da competência oocitária.................................................. 20

2.5. Fatores GDF9 e BMP15 e sua importância sobre o funcionamento ovariano.

2.6. Receptores específicos e vias de sinalização dos fatores GDF9 e BMP15.

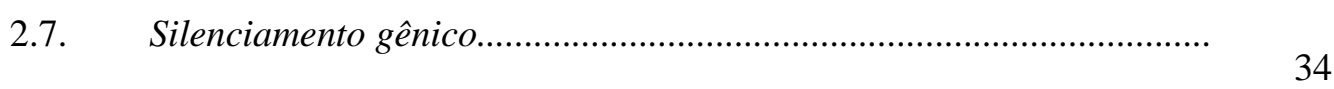

CAPÍTULO III. MATERIAL E MÉTODOS.................................................................... 41

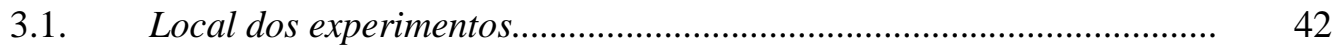

3.2. Obtenção, processamento e cultivo das células da granulosa bovinas.. $\quad 42$

3.3. Padronização do cultivo primário de células da granulosa .................. 43

CAPÍTULO IV. EXPERIMENTO I.................................................................................. 48

Resumo

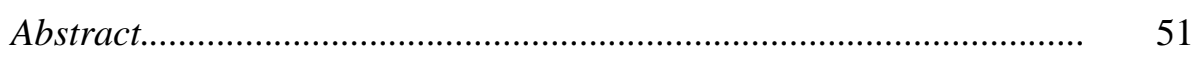

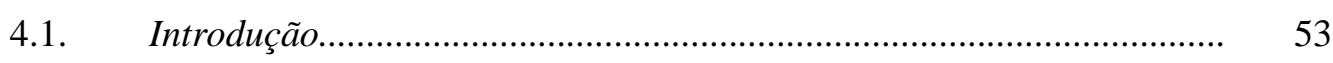

4.2. Material e Métodos......................................................................... 55

4.2.1. Obtenção das células da granulosa ............................................. $\quad 55$ 
4.2.2. Cultivo das células da granulosa.

56

4.2.3. Transfecção mediada por lipossomas (lipofecção) das células 56 da granulosa

4.2.4. Avaliação visual da eficiência lipofecção..................................... 58

4.2.5. Captura das imagens e análise quantitativa dos pixels................ 58

4.2.6. Análise estatística......................................................................... 58

4.3. Resultados..................................................................................... 59

4.3.1. Avaliação do tempo de exposição................................................. $\quad 59$

4.3.2 Avaliação da eficiência lipofecção ............................................. $\quad 59$

4.3.2.1. Lipofectamine ${ }^{\circledR}$ RNAiMAX............................................... 59

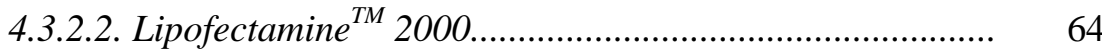

4.4. Discussão..................................................................................

CAPÍTULO V. EXPERIMENTO II.................................................................................. 74

Resumo......................................................................................... 76

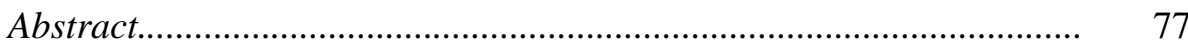

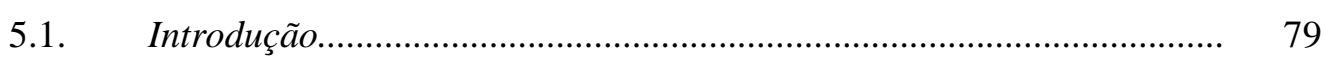

5.2. Material e Métodos............................................................................ 81

5.2.1. Obtenção das células da granulosa ............................................ 81

5.2.2. Cultivo das células da granulosa................................................. 82

5.2.3. Avaliação do comportamento temporal das células da 83 granulosa ao longo de um período de 24 horas

5.2.4. Silenciamento gênico in vitro por lipofecção do siRNA................ 83

5.2.5. Diferentes concentrações de siRNA para o silenciamento 85 gênico do BMPRII.

5.2.6. Diferentes períodos de incubação com o siRNA para o 86 silenciamento gênico do BMPRII

5.2.7. Avaliação visual da eficiência lipofecção

5.2.8. Coleta e processamento das amostras de células da granulosa.. $\quad 86$

5.2.9. Extração do RNA total pelo método de Trizol®............................ 87

5.2.10. Digestão das amostras de RNA com DNAse I............................. 87

5.2.11. Reação de Transcrição Reversa $(R T)$.......................................... $\quad 88$

5.2.12. Investigação da expressão gênica por PCR em tempo real...... 88

5.2.13. Análise dos dados obtidos por PCR em tempo real ................... $\quad 90$

5.2.14. Detecção da proteína por western blotting ............................... $\quad 91$

5.2.15. Análise estatística.......................................................................... 93

5.2.16. Delineamento Experimental........................................................ 94 


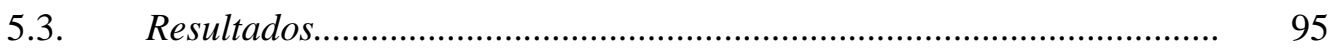

5.3.1. Avaliação da eficiência dos genes endógenos e determinação 95

da melhor diluição para as amostras de cDNA

5.3.2 Expressão Temporal do BMPRII ................................................. 97

5.3.3 Análise dos diferentes controles ................................................... 98

5.3.4 Determinação da melhor concentrações de siBMPRII às $24 \quad 100$ horas de cultivo

5.3.5 Determinação do melhor período de incubação com 100 pM de 102 SiBMPRII

5.3.6 Detecção da proteína por western blotting

104

5.4. Discussão.............................................................................................. 106

CAPÍTULO VI. CONCLUSÕES.......................................................................... 112

CAPÍTULO VII. REFERÊNCIAS BIBLIOGRÁFICAS................................................ 113 
CAPÍTULO I

\section{Introdução}




\section{INTRODUÇÃO}

O folículo ovariano é a unidade funcional do ovário na qual os componentes somático (células tecais e granulosas) e germinativo (oócito), são intimamente associados e interdependentes. O ovário é responsável pelo desenvolvimento dos folículos e pela ovulação, bem como pela produção de hormônios sexuais que agem no trato reprodutivo (MOENTER et al., 1992).

Durante a oogênese, o oócito adquire a maquinaria molecular e citoplasmática necessária para suportar o desenvolvimento embrionário em um processo denominado capacitação oocitária (GILCHRIST et al., 2008). No entanto, pode-se dizer que, durante o processo de maturação in vitro, o oócito não é auto-suficiente para concluir o seu desenvolvimento, maturação e capacitação. O desenvolvimento completo do oócito dentro da estrutura folicular exige uma comunicação bi-direcional constante entre o oócito e as células do cumulus que o circundam (complexo cumulus-oócito) e as demais células somáticas incluídas no folículo, tais como as da teca e as da granulosa (GANDOLFI et al. 2005).

A interação oócito-células da granulosa in vivo e in vitro, assim como sua influência na qualidade oocitária e embrionária tem sido alvo de inúmeros estudos, mas muitas questões ainda necessitam ser esclarecidas. Sabe-se que as células da granulosa são um dos constituintes do ambiente folicular de grande importância para a aquisição da competência oocitária, visto que desempenham funções necessárias ao desenvolvimento e capacitação adequados do oócito. Essas funções são variadas envolvendo a produção de esteroides (estradiol e progesterona), expressão de receptores de LH (LHR), secreção de inibina A e B (INHA e INHB), síntese de inúmeras proteínas essenciais, além da produção e secreção de fatores químicos necessários para manter o oócito em bloqueio meiótico (RICHARD e SIRARD, 1996).

Diante dos estudos envolvendo células da granulosa e sua interação com os oócitos, é possível concluir que tais células são de suma importância para o desenvolvimento oocitário, ovulação e fertilização em mamíferos. Contudo, a funcionalidade e ação destas células são dependentes de alguns fatores derivados do oócito, capazes de atuar diretamente nos processos coordenados de maturação folicular através de uma sinalização parácrina (LI et al. 2008b; HUTT e ALBERTINI, 2007). 
Dentre os fatores secretados pelo oócito, se destacam os membros da superfamília TGF $\beta$ e, dentre estes, o GDF9 (growth and differentiation factor 9) e o BMP15 (bone morphogenetic protein 15), que são expressos em todos os estágios do desenvolvimento folicular na espécie bovina e estão envolvidos no controle da proliferação e esteroidogênese das células da granulosa (JUEGEL e MCNATTY, 2005). Esses fatores são fundamentais para a ativação dos folículos primordiais e posterior desenvolvimento e diferenciação folicular. Além disso, estão envolvidos nas etapas finais do processo de maturação e nos eventos que antecedem a ovulação como, por exemplo, a expansão das células do cumulus oophurus (DONG et al. 1996; HANRAHAN et al., 2004; YOSHINO et al,. 2006). No entanto, a ação desses fatores depende da sinalização via o receptor da proteína morfogenética óssea tipo II (BMPRII), receptor este já identificado em células da granulosa de mamíferos e que possui vital importância para a funcionalidade destas células e do oócito (MAZERBOURG e HSUEH, 2006).

O GDF9 também é responsável por controlar a expressão de alguns genes nas células da granulosa. A proteína Gremlin teve sua expressão aumentada pelo GDF9 em células da granulosa murinas (PANGAS et al, 2004), assim como outros genes, que também tiveram sua expressão aumentada, como a inibina B (INHB) e a proteína regulatória da esteroidogênese aguda (StAR), ou suprimida como a inibina A (INHA) e o receptor de LH (LHR) (MAZERBOURG e HSUEH, 2006).

Células da granulosa cultivadas in vitro, mesmo durante o processo de luteinização, continuam expressando os receptores para BMPRII. Portanto, essas células mantêm a total capacidade de reconhecer e responder ao estímulo do GDF9 durante o cultivo in vitro em qualquer fase de desenvolvimento folicular (RUA et al., 2009).

A técnica de RNA de interferência (RNAi), utilizada para o silenciamento gênico, consiste numa importante ferramenta para investigar a função de proteínas celulares (BARBOSA e LIN, 2004). Dentre os diversos métodos desenvolvidos com o intuito de transportar o RNAi para o interior da célula, a lipofecção pode ser considerada uma das técnicas mais eficientes e amplamente utilizada no silenciamento gênico de células in vivo e in vitro. Tal técnica utiliza lipossomas para a transfecção, os quais encapsulam o ácido nucléico a ser transfectado devido à diferença de cargas elétricas e, neste sistema, o complexo lipídio-ácido nucléico é então internalizado por endocitose. A lipofecção consiste num método bastante eficiente e pouco agressivo para as células, representando 
uma importante ferramenta para investigar a função de determinados genes e proteínas celulares.

Diante da importância do BMPRII para a funcionalidade das células da granulosa e, consequentemente, dos oócitos que se desenvolvem no ambiente folicular, e visto que o papel deste receptor em células da granulosa bovinas ainda é pouco conhecido, o objetivo do presente trabalho foi desenvolver uma metodologia especificamente para promover o silenciamento gênico do BMPRII em células da granulosa bovinas, utilizando a técnica de RNA de interferência por lipofecção. Esta técnica ainda é pouco utilizada e padronizada nestas células, e o desenvolvimento de um protocolo apropriado possibilitaria sua utilização como ferramenta para o estudo funcional e investigação mais acurada do papel do BMPRII e de outros genes de interesse. Portanto, tal metodologia poderá ser eficientemente empregada para a obtenção de maiores informações a respeito da interação entre as células da granulosa e os oócitos bovinos, permitindo, dessa forma, o desenvolvimento de condições de cultivo in vitro mais adequadas à promoção de melhores resultados na produção in vitro de embriões, e conseqüente aplicação prática.

\subsection{Hipóteses}

O silenciamento gênico realizado a partir da técnica de RNA de interferência, pelo processo de lipofecção, pode ser utilizado eficientemente em células da granulosa bovinas sem promover danos relevantes às mesmas;

O silenciamento do gene BMPRII em células da granulosa bovinas, proporciona uma redução de sua expressão (RNAm e proteína).

\subsection{Objetivos}

\subsubsection{Objetivo Geral}

O objetivo geral do presente trabalho foi desenvolver uma metodologia de silenciamento gênico por lipofecção em células da granulosa bovinas e utilizar tal protocolo para o silenciamento do gene BMPRII nestas células, criando uma ferramenta para investigar sua função nessas células. 


\subsubsection{Objetivos Específicos}

1) Padronizar a lipofecção em células da granulosa bovinas, estabelecendo as melhores condições para promover o silenciamento gênico do BMPRII (concentração do RNA de interferência e tempo de exposição) em células da granulosa bovinas;

2) Determinar o efeito do silenciamento gênico nas células da granulosa bovinas sobre a expressão de BMPRII (RNAm e proteína); 
CAPÍTULO II

Revisão de Literatura 


\section{REVISÃO DE LITERATURA}

\subsection{O ovário mamífero}

O ovário mamífero é um órgão complexo composto de vários tipos celulares que incluem oócitos, células da granulosa, da teca, do estroma e do epitélio superficial ovariano. Estes tipos celulares estão localizados na região cortical do ovário e, posteriormente, se diferenciam em vários subtipos celulares. As células da granulosa, por exemplo, diferenciam-se em células do cumulus e murais, enquanto que as células da teca desenvolvem-se em camadas internas e externas (ERICKSON e SHIMASAKI, 2003). A região medular é localizada na porção mais interna do ovário, sendo esta constituída por tecido conjuntivo (fibroblastos, fibronectina e fibras colágenas do tipo I e II), nervos, vasos sangüíneos e linfáticos responsáveis pela nutrição e sustentação do ovário. Além dos nutrientes e hormônios provenientes da corrente sangüínea, outros fatores produzidos pelos diferentes tipos celulares descritos contribuem para a formação de um sistema bastante complexo que regula as funções ovarianas, que incluem a produção de gametas e hormônios (SILVA, 2004).

\subsection{Desenvolvimento folicular: aspectos morfológicos e cronologia da formação folicular}

Os folículos são unidades morfofuncionais do ovário, constituídos por um oócito (componente germinativo) circundado de uma ou várias camadas de células somáticas. Estes são classificados de acordo com o estágio de progressão em folículos pré-antrais não cavitários, que representam aproximadamente $95 \%$ de toda população folicular, e folículos antrais cavitários (FIGUEIREDO et al., 2007). No interior dos folículos, os componentes germinativos e somáticos são intimamente associados e interdependentes (MOENTER et al., 1992).

A foliculogênese pode ser definida como o processo de formação, crescimento e maturação folicular, iniciando-se com a formação do folículo primordial e culminando com o estádio de folículo de Graaf ou pré-ovulatório (SAUMANDE, 1991). A oogênese e a foliculogênese são processos coordenados que se iniciam durante a vida fetal das 
fêmeas mamíferas, quando as células germinativas se diferenciam em oogônias e se proliferam por mitose para, posteriormente, entrar em processo de meiose e se tornar um oócito primário, que ficará retido no estágio de prófase I da meiose (AUSTIN e SHORT, 1982). Durante a vida fetal, a formação dos folículos primordiais em ovários de bovinos é observada aos 120 dias (RÜSSE, 1983).

Ao nascer, as fêmeas de mamíferos apresentam ovários contendo milhares de folículos primordiais. Durante a infância ocorre um decréscimo no número de folículos, e somente 300 a 500 desses oócitos vão se desenvolver em oócitos maduros. Esse declínio progressivo no número de oócitos ocorre devido ao processo de apoptose que comanda a atresia folicular (VASKIVUO e TAPANAINEN, 2003). Anteriormente ao início da puberdade, a maioria dos folículos primordiais em crescimento degenera-se devido às baixas concentrações de hormônios hipofisários, que fazem com que estes folículos não tenham o estímulo necessário para desencadear a ovulação. Ao início da puberdade, por ação hormonal, ocorre a retomada e finalização da meiose I (SKINNER 2005; HUTT et al., 2006).

O ovário contém folículos em diferentes estádios de desenvolvimento e produz mínimas quantidades de estrógenos que são suficientes para manter a hipófise inibida durante a infância. A promoção da ativação do eixo hipotálamo-hipófise-ovário no início da puberdade é controversa. A princípio, há uma imaturidade deste eixo e a secreção do GnRH tem pulsatilidade irregular, assim como as gonadotrofinas, por isso não existe uma capacidade de promover um desenvolvimento folicular completo e consequentemente, os ciclos são anovulatórios. Conforme ocorre a maturação do eixo, os ciclos assumem um padrão ovulatório com completa sincronia entre o GnRH, o FSH e o LH. Hoje já se sabe que não há somente uma interação entre as gonadotrofinas e as células somáticas foliculares, mas também um intercâmbio de substâncias entre estas células e os oócitos (GILCHRIST et al., 2008).

Os folículos podem ser classificados em três estágios de desenvolvimento de acordo com seu tamanho e dependência em relação aos hormônios gonadotrofinas. $\mathrm{O}$ primeiro estágio é independente de gonadotrofinas, no qual ocorre a ativação dos folículos primordiais, onde os oócitos encontram-se circundados apenas por uma camada de células somáticas fusiformes do estroma, precursoras das células da granulosa. A maioria das células precursoras da granulosa é recrutada das células mesoteliais oriundas do epitélio da superfície ovariana que tem alta atividade proliferativa. O invólucro mais 
externo do folículo é denominado lâmina basal. Durante essa fase inicial do desenvolvimento folicular, as células da granulosa compreendem uma população homogênea de células em proliferação que adquirem receptores para FSH e hormônios esteroides (SAWYER et al., 2002).

Após a ativação, os folículos primordiais deixam o estado quiescente e iniciam o crescimento, diferenciando-se em folículos primários, quando as células precursoras da granulosa assumem uma morfologia cuboide, mas mantendo uma camada única ao redor do oócito, que agora é maior. À medida que os folículos iniciam o crescimento, as proteínas que irão formar a zona pelúcida começam a ser sintetizadas (LEE, 2000). A zona pelúcida é uma matriz extracelular glicoprotéica localizada entre o oócito e as células da granulosa. Em bovinos, o aparecimento de folículos primários, em fetos, ocorre aos 140 dias de gestação (RÜSSE, 1983). Na última etapa do primeiro estágio, que pode ocorrer dias, meses ou anos após a formação do folículo primordial, a camada única de células cuboides entra em divisão e diferenciação, formando múltiplas camadas de células da granulosa, pontos de comunicação entre elas (junções gap) e acúmulo de líquido, e o folículo passa então a ser chamado de secundário (HIRSHFIELD, 1991; BRAW-TAL, 2002). Neste estágio, a zona pelúcida é claramente identificada ao redor do oócito. Quando os folículos possuem de duas a três camadas de células da granulosa, os precursores das células da teca são recrutados do estroma ovariano (PARROT e SKINNER, 2000). Após sua formação, a camada de células da teca permanece separada das células da granulosa pela membrana basal (PETERS, 1969). Os folículos secundários são observados em ovários de fetos bovinos aos 210 dias de gestação (RÜSSE, 1983).

No segundo estágio do desenvolvimento folicular, o folículo é caracterizado pela formação de multicamadas de células da granulosa e por sua diferenciação. Essas células diferenciadas secretam um fluido, denominado de fluido ou líquido folicular, que culmina com a formação de um espaço intersticial nomeado antro. A partir de então, os folículos secundários (pré-antrais) passam a ser classificados como antrais. A forma desse folículo se torna ovalada e o oócito é deslocado para um dos polos e se fixa à parede folicular através do cumulus-oócito. O fluido folicular é repleto de substâncias derivadas do sangue e secreções de células foliculares como gonadotrofinas, esteroides e fatores de crescimento protéicos, e isto permite a continuação do desenvolvimento do folículo selecionado até a ovulação, aumentando a proliferação das células da granulosa e o número de receptores de FSH (VAN DER HURK e ZHAO, 2005). A formação dos 
folículos antrais em bovinos é observada aos 230 dias (RÜSSE, 1983). A partir deste estágio, o diâmetro folicular aumenta acentuadamente devido ao crescimento do oócito, incremento no número de células da granulosa, da teca e aumento da cavidade antral (PEDERSON e PETERS,1968).

Com a formação do antro folicular, as células da teca se desenvolvem plenamente, sofrendo alterações morfológicas e funcionais, sendo que as células localizadas próximas da membrana basal são denominadas teca interna enquanto que as localizadas perifericamente são comprimidas e classificadas como teca externa. Este estágio é responsivo, mas não dependente de gonadotrofinas (GILLOT et al., 2008).

Durante o desenvolvimento do folículo antral, ondas de crescimento folicular emergem sob o controle das gonadotrofinas (FSH e LH), hormônios esteróides ovarianos (estradiol e progesterona) e fatores ovarianos de ação endócrina e parácrina (FORTUNE, 1994; GONG et al., 1996; WEBB et al., 2003). Neste ponto ocorre uma atuação intensa dos fatores de crescimento protéicos de ação parácrina da superfamília de fatores de crescimento transformadores $\beta$ (TGF $\beta$ ), envolvidos diretamente com a proliferação das células somáticas.

Com o crescimento, desenvolvimento folicular e consequente formação do antro, as células da granulosa primárias se diferenciam em duas distintas populações celulares, que diferem quanto à localização folicular e aspectos morfofuncionais: as células do cumulus, que circundam o oócito e estão intimamente ligadas ao este, estabelecendo um contato metabólico essencial com o mesmo; e as células da granulosa murais, que consistem na linhagem celular da parede folicular e que formam um epitélio estratificado em contato com a lâmina basal. As células do cumulus têm maior capacidade de proliferação que as murais, talvez por ação de substâncias parácrinas liberadas pelo oócito (GILLOT et al., 2008). O crescimento e a diferenciação do oócito e das células somáticas nos folículos ovarianos dependem de uma comunicação bidirecional essencial para o desenvolvimento dos dois tipos celulares e são orquestrados de forma coordenada e mutuamente dependente (EPPIG, 2001).

As células da granulosa mostram grandes mudanças morfológicas e ultraestruturais, com distintos graus de diferenciação de acordo com sua localização folicular, estádio de desenvolvimento do folículo ovariano e também de acordo com a fase do ciclo estral. Nos estádios mais avançados do desenvolvimento folicular, as células da granulosa murais adquirem propriedades funcionais e morfológicas distintas: as 
localizadas na periferia, adjacentes à membrana basal, se alongam e formam um epitélio pseudoestratificado, denominadas murais; as células localizadas nas camadas mais internas que contornam o antro folicular, denominadas células da granulosa antrais, juntamente com as células do cumulus permanecem poliédricas-arredondadas e continuam a proliferar (GILLOT et al., 2008). Existem também evidências de diferenças morfológicas e funcionais entre células da granulosa antrais e murais em relação à expressão de receptores de FSH e taxa de mitose (GILCHRIST et al., 2008). As células da granulosa antrais e murais também parecem diferir quanto à capacidade esteroidogênica in vivo e in vitro; as células da granulosa antrais bovinas secretam significativamente mais esteroides in vitro que as células da granulosa murais (ROUILLIER et al., 1997).

Diferentemente das células do cumulus, as células murais apresentam número progressivamente maior de receptores para o $\mathrm{LH}$ ao longo do desenvolvimento folicular (JOYCE et al., 2000). Apesar da similaridade desses dois tipos celulares, existem diferenças na produção de transcritos e proteínas (LATHAM et al., 1999). Além disso, essas células desempenham funções distintas ao longo de toda a foliculogênese: as células do cumulus parecem ser especializadas em oferecer suporte nutricional para o crescimento e desenvolvimento do oócito e têm papel fundamental no seu crescimento e metabolismo (HAGHIGHAT e VAN WINKLE, 1990); já as células da granulosa murais possuem função endócrina e maior atividade esteroidogênica do que as células do cumulus, dando suporte ao crescimento do folículo (LI et al., 2000). O oócito, por sua vez, secreta fatores que agem nas células do cumulus e células da granulosa murais, essenciais para a regulação da função ovariana (EPPIG, 2001; GILCHRIST et al., 2004; McNATTY et al., 2004). A competência adquirida durante a foliculogênese, através dessa comunicação mútua, torna o oócito capaz de completar a meiose, ser fecundado, passar pela transição materno-zigótica e prosseguir seu desenvolvimento (COTICCHIO et al., 2004).

No terceiro e último estágio de desenvolvimento, o folículo pré-ovulatório é caracterizado por um oócito circundado de células da granulosa especializadas, as células do cumulus (PEDERSON e PETERS, 1968). Este folículo produz grandes quantidades de estrógeno. Tanto o oócito como as células do cumulus estão conectados com a parede folicular e são banhados pelo fluido folicular e, nesta fase, há dependência de gonadotrofinas e os folículos continuam a crescer após a formação do antro até o 
recrutamento, seleção, maturação e ovulação (CATTANACH et al., 1977; KUMAR et al., 1997; McGEE e HSUEH, 2000). As células da granulosa e o oócito são separados das outras camadas foliculares pela membrana basal, acima da qual se encontram as tecas interna e externa. As células da granulosa de folículos pré-ovulatórios param de se multiplicar em resposta ao hormônio luteinizante $(\mathrm{LH})$ e iniciam o programa final de diferenciação. A ovulação ocorre apenas em resposta ao pico de LH. Imediatamente após a ovulação ocorrem profundas alterações na organização celular, onde o folículo se transforma em uma glândula endócrina denominada corpo lúteo, a qual secreta quantidades consideráveis de progesterona e estradiol. É nesse momento que, pela primeira vez, as células da granulosa tornam-se acentuadamente luteinizadas pela incorporação de vacúolos ricos em lipídios dentro do citoplasma. O hormônio luteinizante é o principal responsável pela ovulação e formação do corpo lúteo, considerando que o FSH é essencial para o desenvolvimento folicular ovariano. Em todas as espécies, a formação de folículos pré-ovulatórios ocorre geralmente durante a puberdade (LUCY et al., 1992). As características morfológicas das distintas categorias foliculares descritas são mostrados nas Figuras 1 e 2.

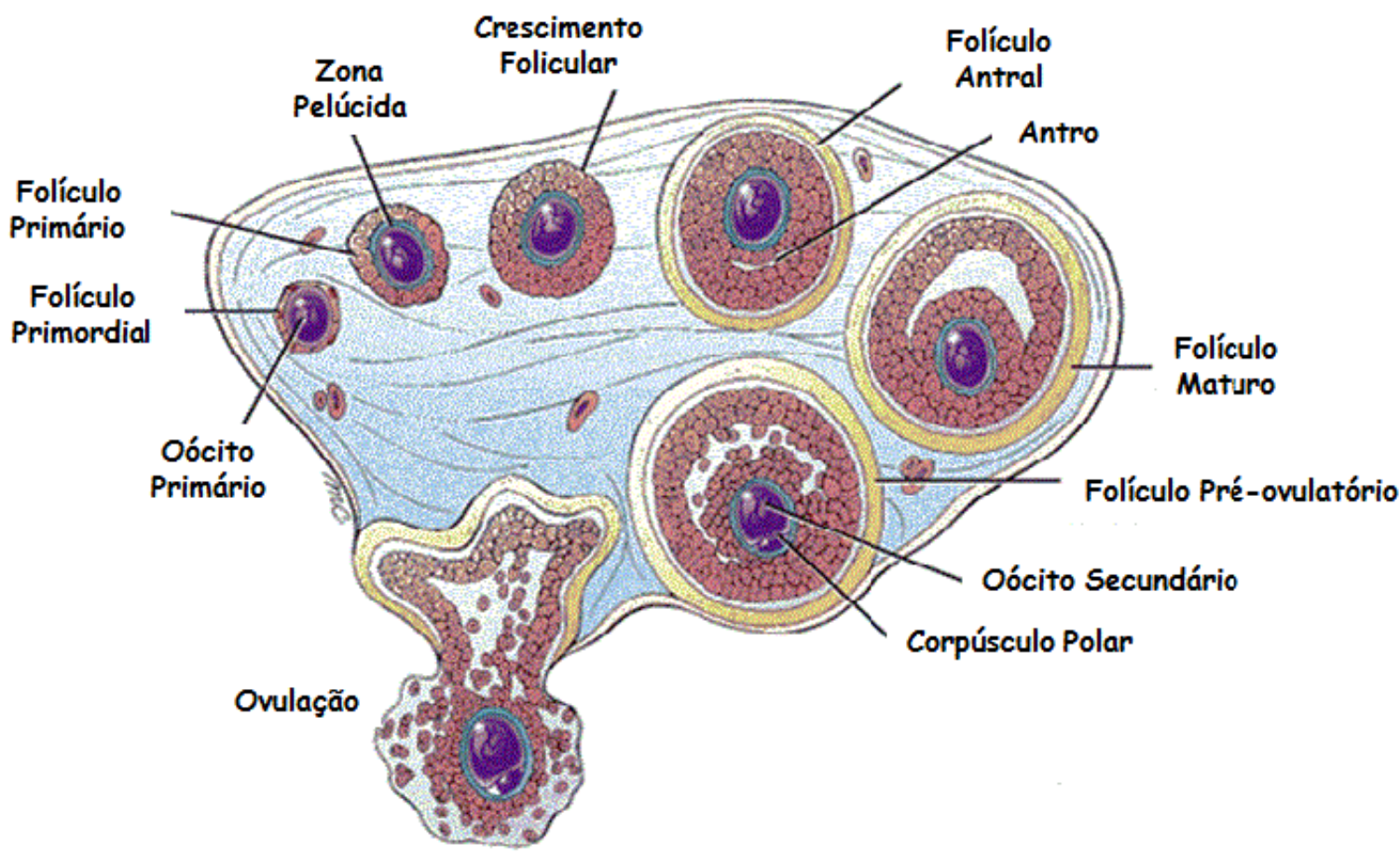

Figura 1. Representação esquemática do desenvolvimento folicular até a ovulação no interior do ovário mamífero (Adaptado de Schoenwolf et al., 2008). 


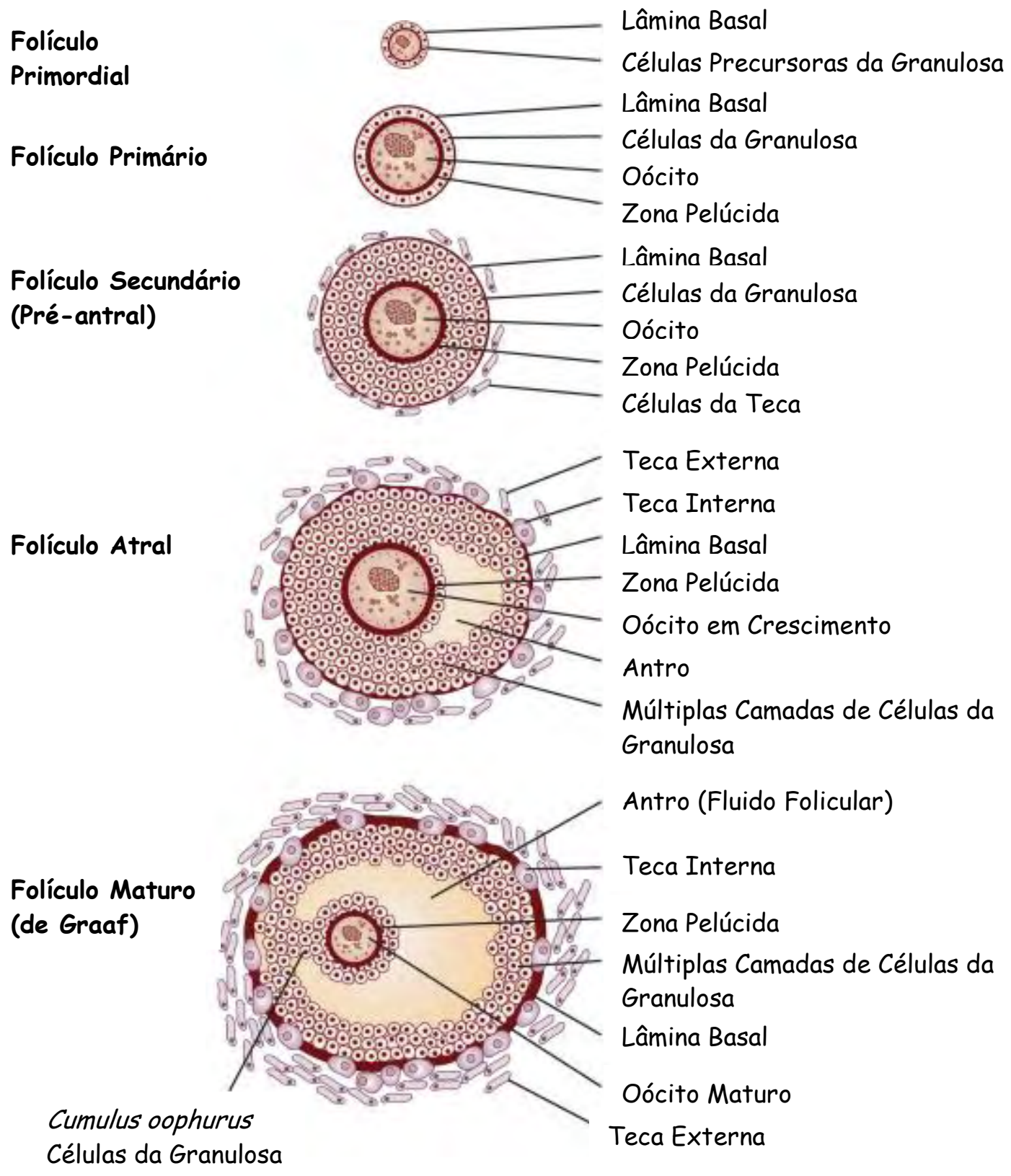

Figura 2. Aspectos morfológicos dos diferentes estágios do desenvolvimento folicular (Adaptado de ERICKSON et al., 1985).

A foliculogênese e a oogênese são processos coordenados por sinais endócrinos, parácrinos e substâncias que trafegam entre as células do cumulus e o oócito pelas junções comunicantes. O oócito possui papel essencial na sinalização das células da granulosa foliculares, pela secreção de fatores que atuam nas células somáticas e, posteriormente, estimulam o crescimento oocitário, resultando em oócitos maduros e competentes para a fertilização e desenvolvimento embrionário (HICKEY et al., 2005; 
FIGUEIREDO et al., 2007). Através destes sinais, o desenvolvimento é regulado pelas células da granulosa e do cumulus, de maneira que nenhum folículo seja formado sem a presença de um oócito. A secreção desses fatores induz a formação de novos folículos primordiais, conduz a proliferação de células somáticas, regula a esteroidogênese, mantendo a arquitetura complexa do desenvolvimento folicular (AMLEH e DEAN, 2002).

\subsection{Interação entre o oócito, células do cumulus e células da granulosa}

Por um bom tempo, acreditava-se que os oócitos de mamíferos eram passivos na relação com suas células somáticas foliculares circundantes. Entretanto, há alguns anos surgiu um novo paradigma na biologia oocitária. Tornou-se evidente que o oócito, na verdade, é o centro regulador de funções das células foliculares e que desempenha um papel importante na regulação da oogênese, das taxas de ovulação e fecundidade, por meio da secreção parácrina de fatores de crescimento solúveis (GILCHRIST et al., 2004; GILCHRIST e THOMPSON, 2007).

A comunicação entre as células do cumulus, da granulosa e o oócito ocorre de maneira bidirecional e é essencial para a maturação nuclear e citoplasmática e, consequentemente, para aquisição da competência oocitária, fertilização e geração de um embrião com alto potencial de desenvolvimento (TANGHE et al., 2002; FAIR, 2003). Sendo assim, o aprofundamento dos conhecimentos sobre as interações entre as células somáticas e germinativas que formam o complexo cumulus-oócito (CCO), assim como suas exigências é necessário para a melhoria da eficiência da maturação oocitária in vitro (MIV). Compreendendo-se melhor essas interações, os meios de cultivo poderiam ser aprimorados de forma a minimizar o impacto da perda da unidade folicular durante o cultivo in vitro.

As células da granulosa e do cumulus se comunicam com o oócito por meio de processos citoplasmáticos trans-zonais (TZP), que consistem em extensões das células da granulosa que penetram através da zona pelúcida e atingem a membrana do oócito, onde uma rede extensiva de canais transmembrana conhecidos como junções gap ou junções comunicantes, permite o transporte bidirecional de íons, metabólitos, aminoácidos e pequenas moléculas reguladoras (ALBERTINI et al., 2001). As junções gap permitem a 
transferência de moléculas de pequeno peso molecular entre as células do cumulus e o oócito, enquanto que moléculas grandes são transportadas por endocitose mediada por receptores. Além da comunicação por junções gap, a interação entre o oócito e as células somáticas que o circundam também ocorre por sinalização parácrina (Figura 3).

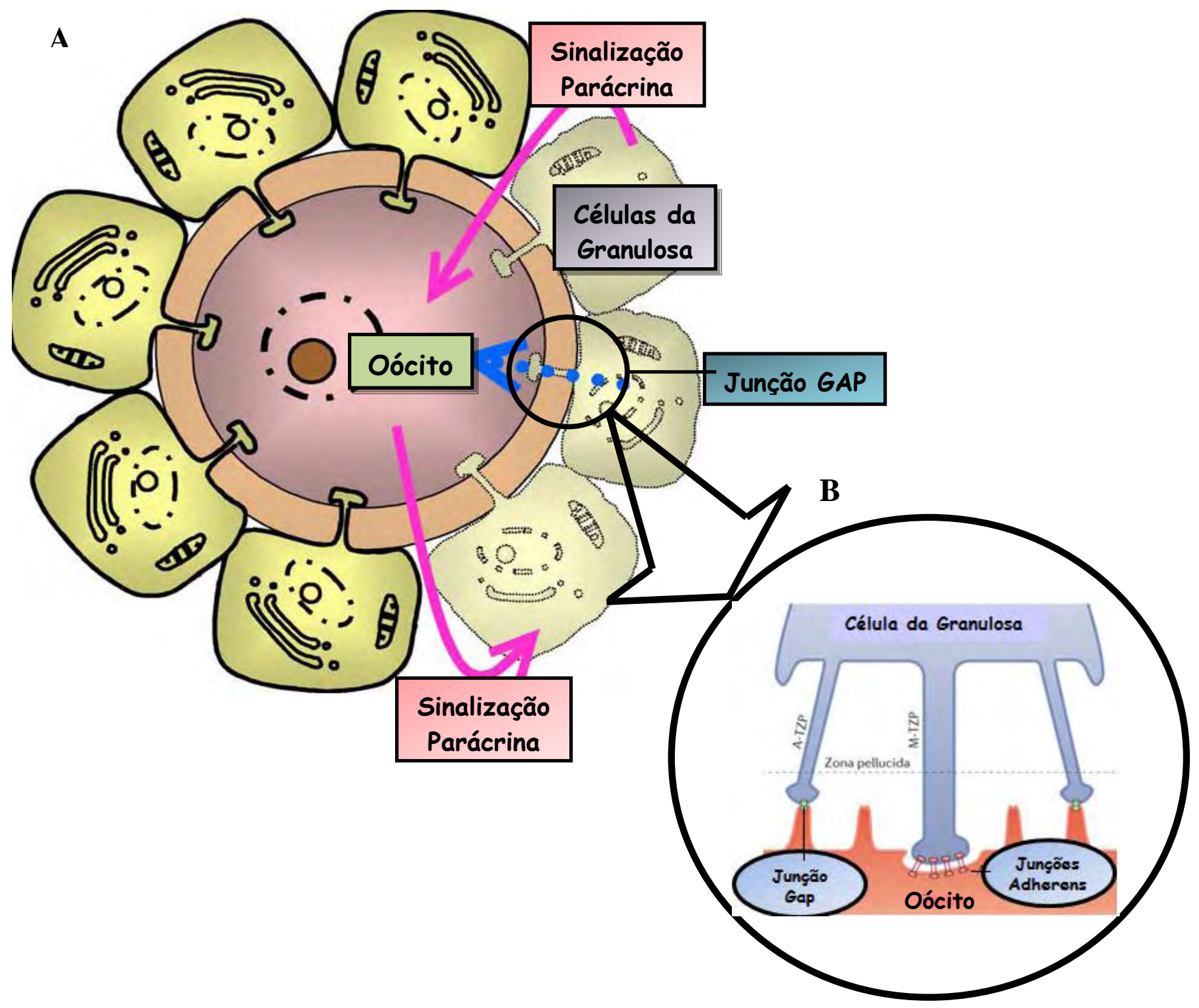

Figura 3. Comunicação celular entre o oócito e as células do cumulus, essencial para o crescimento normal e desenvolvimento tanto do oócito quanto do folículo. A) A comunicação ocorre através de sinalização parácrina (setas rosa) e de trocas por junções gap de pequenas moléculas reguladoras (seta azul). Este é um eixo de comunicação bi-direcional entre o oócito e as células do cumulus. B) Projeções trans-zonais (TZP) a partir de células do cumulus, que atravessam a zona pelúcida e formam junções intercelulares do tipo gap no interior de 
invaginações profundas na superfície do oócito. TZPs podem ser ricas em F-actina (A-TZP), ou compostos principalmente de microtúbulos (M-TZP) (Modificado de SUTTON et al., 2003).

Os métodos de comunicação bidirecional entre células germinativas e somáticas são essenciais para o desenvolvimento, maturação e disseminação de sinais endócrinos e parácrinos que atuarão no oócito e nas células do cumulus (VANDERHYDEN et al., 1992; SIMON et al., 1997; DAIKOKU e ORISAKA, 2009).

A presença de células foliculares circundando o oócito é imprescindível para a obtenção de bons resultados na produção in vitro de embriões (PIV). A utilização de oócitos desnudos na PIV poderá comprometer todo o processo, visto que estes frequentemente não possuem competência para se desenvolver em um embrião viável após a fecundação. A presença das células do cumulus é benéfica para a obtenção de embriões bovinos após fertilização in vitro (FIV), pois a eliminação destas células, antes do processo de maturação, diminui a taxa de maturação, fertilização e desenvolvimento embrionário até o estádio de blastocisto. Além disso, estas células ainda atuam na atração e seleção de espermatozoides, facilitam a capacitação espermática, reação acrossomal e penetração, visto que previnem o endurecimento precoce da zona pelúcida, tornando-se, portanto, de suma importância para a fecundação (ANCIOTO et al., 2004).

Além da importância da comunicação bidirecional entre as células do cumulus e o oócito, a comunicação entre as células da granulosa e o oócito também é essencial para a foliculogênese, crescimento e maturação oocitária (GILCHRIST et al.,2004). Os benefícios proporcionados pela presença dessas células somáticas durante a maturação in vitro podem ser atribuídos à formação de um microambiente complexo e favorável (bioquímico e metabólico) ao redor do oócito (Sutton et al., 2003).

As células da granulosa exercem, portanto, um papel crucial no desenvolvimento folicular e oocitário e, consequentemente, nos processos de fertilização e produção de embriões in vitro (FIV e PIV). Em contrapartida à importância que as células da granulosa exercem sobre os oócitos, os oócitos também têm um papel fundamental na regulação dessas células. A partir da produção de fatores parácrinos, o oócito é responsável pela proliferação e função das células da granulosa, além de influenciar expressivamente a esteroidogênese (VANDERHYDEN, 1996).

Durante muito tempo, o controle da foliculogênese foi atribuído apenas aos fatores endócrinos, através de mecanismos mediados pelo eixo hipotalâmico - 
hipofisário-gonadal com ação direta no sistema reprodutivo (PAULINI, 2010). Nesta visão, os eventos que ocorrem durante o ciclo estral são regulados basicamente pela interação dos hormônios: liberador de gonadotrofinas $(\mathrm{GnRH})$, folículo estimulante (FSH), luteinizante (LH), estradiol $\left(\mathrm{E}_{2}\right)$ e progesterona $\left(\mathrm{P}_{4}\right)$ (HAFEZ e HAFEZ, 2004). O GnRH é produzido pelo hipotálamo e regula a liberação das gonadotrofinas já, o FSH e o LH, são produzidos pela glândula hipófise anterior e são responsáveis pelo desenvolvimento folicular e ovulação (VALLE e DONE, 1991; HAFEZ e HAFEZ, 2004).

Entretanto, desde que as ações dos hormônios secretados pelo hipotálamo (GnRH) e hipófise anterior (FSH e LH) foram bem caracterizadas por diversos estudos, surgiram novas pesquisas com foco na regulação de determinados genes e proteínas sinalizadoras no interior dos ovários, os quais possuem ação no desenvolvimento folicular através de interações estabelecidas entre as células da granulosa e os fatores secretados pelo oócito (RICHARDS, 1994; KNIGHT e GLISTER, 2001; WEBB et al., 2003).

Hoje, sabe-se que os fatores secretados pelo oócito regulam a foliculogênese através da modulação do crescimento e diferenciação celular, além de possuírem ação mitogênica e interagirem com hormônios reguladores das células somáticas, como o FSH, fator de crescimento semelhante à insulina - I (IGFI) e andrógenos (ARMSTRONNG et al., 1996; LANUZA et al., 1998; LI et al., 2000; HICKEY et al., 2004). Apesar dos processos celulares e moleculares envolvidos nas interações estabelecidas entre o oócito e as células da granulosa serem ainda pouco elucidados, é evidente que a comunicação entre essas células germinativas e somáticas ocorre por sinalização parácrina intermediada pelos fatores secretados pelo oócito (HSUEH et al., 1984; DONG et al., 1996; McNATTY et al., 2004).

Dentre os diversos fatores de crescimento produzidos pelo oócito e propagados às células da granulosa, estão os membros da superfamília dos fatores de crescimento transformantes- $\beta$ (TGF- $\beta$ ), que têm recebido a maior parte da atenção em pesquisas nesta área (WEBB et al., 2003). Sabe-se que os membros da superfamília TGF- $\beta$, tais como o fator de crescimento e diferenciação 9 (GDF-9) e a proteína morfogênica óssea 15 (BMP15), secretados pelo oócito, são importantes reguladores de funções celulares como proliferação e diferenciação celular, esteroidogênese, apoptose e expansão das células do cumulus, e melhoram consideravelmente a competência de desenvolvimento do oócito (EPPIG, 2001; MATZUK et al., 2002; GILCHRIST et al., 2004; HUSSEIN et al., 2005). 
A expressão alterada ou nula desses fatores pode causar danos severos sobre a função ovariana e a fertilidade (McNATTY et al., 2004; GILCHRIST et al., 2004).

Gilchrist et al. (2008) desenvolveram um modelo de cultivo para determinar a atividade biológica dos fatores secretados pelo oócito por meio da análise de sua influência sobre o crescimento das células da granulosa, chamado de bioassays of native OSFs. O fundamento desse modelo foi co-cultivar células da granulosa ovarianas na presença de oócitos denudados (DOs) e comparar a resposta delas com a de células da granulosa que foram cultivadas na ausência de DOs. Foi observado que a presença dos DOs na co-cultura alterou drasticamente as funções das células da granulosa murais e do cumulus in vitro, e como esses dois tipos celulares não estavam em contato físico um com o outro, demonstrou-se que esse efeito era mediado por fatores solúveis que foram secretados pelos DOs no meio de cultivo e consequentemente as afetaram (GILCHRIST et al., 2008).

Concluiu-se, a partir de vários ensaios, que o oócito regula as funções das células da granulosa e do cumulus em relação a:

\section{Regulação do kit ligante das células da granulosa:}

O kit ligante é produzido pelas células da granulosa pré-antrais e promove o crescimento do oócito através do receptor localizado no oolema. Os fatores secretados pelo oócito, tais como o GDF-9 e o BMP-15, desempenham um papel fundamental nessa regulação. O GDF-9 inibe a expressão do kit ligante pelas células da granulosa enquanto o BMP-15 estimula (GILCHRIST et al., 2008).

\section{Estímulo de proliferação das células da granulosa e das do cumulus:}

Os oócitos secretam substâncias que estimulam a mitose (oocyte-secreted mitogens) das células da granulosa e do cumulus. Foi observado que quanto mais DOs eram colocados nos poços de cultivo, maior era a síntese de DNA pelas células da granulosa, ou seja, estavam se multiplicando em maior intensidade devido a esses fatores secretados. Esse crescimento era analisado pela incorporação de timidina pelas células da granulosa, que é um marcador para síntese de DNA (GILCHRIST et al., 2008). 


\section{Prevenção de apoptose das células da granulosa:}

Quando o oócito era microcirurgicamente retirado e deixava-se somente o cumulus (OOX) no meio de cultivo, era observado um aumento de apoptose nas células do cumulus, porém quando eram expostas aos fatores secretados por oócitos, esse processo era revertido (GILCHRIST et al., 2008). Isso pode ser explicado devido ao fato de o oócito promover a expressão de proteínas anti-apoptóticas Bcl-2 e suprimir proteínas pró-apoptose Bax nas células do cumulus. Esse estudo também provou que quanto maior a distância das células da granulosa em relação ao oócito, maior era o índice de apoptose dessas células, comprovando mais uma vez o papel protetor dos fatores secretados pelo oócito (HUSSEIN et al., 2005).

\section{Prevenção da luteinização folicular:}

O marco da luteinização das células da granulosa é a sua produção esteroidogênica, principalmente de progesterona. As células do cumulus, adjacentes ao oócito, produzem baixos níveis de progesterona, comparadas com as células da granulosa murais do mesmo folículo. Quando se retirava o oócito do complexo (OOX), ocorria uma dramática luteinização das células da granulosa, havendo um aumento dos transcritos que codificam os marcadores de luteinização, tais como receptor de LH (LHR), LHCGR (EPPIG et al., 1997), P450ssc (enzima da esteroidogênese) e CYP11A1 (DIAZ et al., 2007), levando ao aumento de secreção de progesterona pelas células murinas, bovinas e suínas. Os níveis desses marcadores foram restabelecidos quando os oócitos denudados foram co-cultivados com as células da granulosa e do cumulus, provando que o oócito previne a luteinização de suas células somáticas via ação dos fatores solúveis (GILCHRIST et al., 2008).

\section{Regulação do metabolismo das células da granulosa:}

O oócito e as distintas células somáticas que o circundam possuem diferenças consideráveis em relação à suas atividades e condições metabólicas. A diferença entre as necessidades metabólicas dos oócitos e das células do cumulus sugere que ocorra um fenômeno de regulação entre esses dois tipos celulares. Sugiura et al. (2005) observaram 
que a produção de várias enzimas glicolíticas pelas células do cumulus de folículos antrais de ratos era elevada quando comparada com a produção das células da granulosa murais do mesmo folículo. Tal fato foi confirmado por hibridização in situ. Além disso, mostraram que as células do OOX (complexo cujo oócito foi retirado) apresentavam níveis de RNAm de enzimas glicolíticas e a atividade glicolítica diminuídos, contudo esse nível era restabelecido após o co-cultivo das OOXs com oócitos, comprovando o papel dos fatores solúveis sobre o metabolismo celular das células da granulosa (SUGIURA et al., 2005).

Sem dúvida, tanto o oócito quanto as células somáticas que o circundam, se beneficiam amplamente de um microambiente no qual todos esses componentes (germinativos e somáticos) se mantêm em contato e apropriadamente viáveis. Hussein et al. (2006) demonstraram que o oócito é capaz de criar esse microambiente extremamente favorável e benéfico, tanto em termos bioquímicos quanto em relação a quantidade de metabólitos, utilizando as células somáticas que o cercam.

\subsection{Aquisição da competência oocitária}

Em condições naturais, a maturação oocitária é um processo bastante complexo e controlado pelas gonadotrofinas (FSH e LH) e peptídeos intra-ovarianos e ocorre após um período de crescimento e desenvolvimento no interior do folículo. Neste período, o oócito precisa adquirir a competência para garantir o desenvolvimento embrionário após a fertilização. As células da teca e da granulosa são o principal alvo das gonadotrofinas, que modulam o crescimento e a maturação do oócito. Por outro lado, o oócito expressa genes que controlam a atividade e a diferenciação das células somáticas adjacentes (FEUERSTEIN et al., 2006; 2007). Sabe-se que a aquisição da competência oocitária está intimamente ligada ao fenômeno da foliculogênese, no entanto, um dos grandes desafios que permanecem no campo da reprodução animal é entender a natureza dos processos celulares e moleculares que controlam a aquisição da competência oocitária (CAMPOS et al., 2011).

A maturação realizada in vitro (MIV) é uma técnica reprodutiva que permite que os oócitos atinjam a metáfase II in vitro e adquiram a competência oocitária e, consequentemente, se tornem aptos a serem fecundados e, assim, iniciem a embriogênese (SMITZ et al., 2004). Na maioria das espécies, os oócitos inclusos em folículos 
primordiais presentes no ovário se encontram em estádio quiescente, além de serem pequenos e imaturos. Contudo, em intervalos regulares, certo número deles começa a crescer e maturar, no entanto, de todo esse potencial in vivo, somente um oócito será ovulado e o restante sofrerá atresia (HARDY et al., 2000). Assim, a MIV tem o potencial de resgatar uma grande quantidade de oócitos imaturos ainda no ovário e cultivá-los in vitro até a maturação (GILCHRIST et al., 2008). No entanto, os oócitos maturados in vitro ainda não apresentam o mesmo potencial de desenvolvimento que os oócitos maturados in vivo, daí a necessidade de novos estudos para incrementar a eficiência de técnicas reprodutivas como a maturação e fertilização in vitro (CHIAN et al., 2004).

A competência oocitária é adquirida durante o crescimento e maturação do oócito, através da diferenciação folicular sob controle de gonadotrofinas (TESFAYE et al., 2009). A competência do oócito refere-se à sua habilidade em se desenvolver até um determinado estágio embrionário, após a fecundação in vitro e, em geral, está associada ao tamanho do folículo, ao estágio do ciclo estral e ao nível de atresia influenciado por outros folículos, principalmente pelo folículo dominante (HENDRIKSEN et al., 2000; LONERGAN et al., 1994). A maior falha de desenvolvimento embrionário está relacionada ao início da ativação do genoma embrionário, resultado de uma incompleta maturação oocitária (TESFAYE et al., 2009).

A origem do oócito é crucial para determinar a capacidade de desenvolvimento embrionário (LONERGAN et al., 2003) e pode alterar a quantidade de RNAm do oócito (WATSON et al., 2000). A formação do embrião é diretamente dependente dos transcritos produzidos pelo oócito durante o crescimento e os eventos que cercam a aquisição da competência oocitária (FEUERSTEIN et al., 2006; NOGUEIRA et al., 2006). Diferenças na abundância relativa de transcritos oriundos de embriões produzidos in vivo e in vitro já foram descritas (LONERGAN et al., 2003, TESFAYE et al., 2009) e os processos de cultivo in vitro podem alterar a expressão de genes no período préimplantação de embriões bovinos (RIZOS et al., 2003, WRENZYCKI et al., 2005).

Portanto, a aquisição da competência do oócito pode estar relacionada com a quantidade de transcritos específicos acumulados durante o crescimento oocitário e nas fases finais de foliculogênese, sendo que a diferença entre oócitos competentes e não competentes dependerá de diferentes padrões de expressão gênica (CAIXETA et al., 2009). 
A aquisição de competência oocitária para suportar o desenvolvimento embrionário depende, além da quantidade de transcritos acumulados pelo oócito, de diversas mudanças morfofisiológicas que ocorrem tanto no oócito quanto nas células que o envolvem diretamente (células do cumulus) e nas células somáticas presentes no folículo ovariano (células da teca e da granulosa) (BLONDIN et al. 1997). O processo de maturação oocitária consiste em uma complexa sequência de eventos nucleares e citoplasmáticos (FISSORE et al., 2002). Quando falamos de competência oocitária, estamos nos referindo ao complemento de dois programas celulares: maturação nuclear e maturação citoplasmática do oócito.

Dentro do folículo, o oócito encontra-se em repouso na prófase da primeira divisão meiótica. A maturação nuclear corresponde ao período de retomada da meiose e progressão até a metáfase II, onde ocorre a descondensação da cromatina, desaparecimento da membrana nuclear e dinâmica de separação dos cromossomos, sendo que a quebra de vesícula germinativa é o primeiro sinal visível de retomada da meiose (CROZET et al., 1995; SHARMA et al., 1996; CHA et al., 2000). Estas mudanças conferem ao oócito maturo a capacidade de ser fecundado e desenvolver-se até estágios embrionários precoces (BEVERS et al., 1997). A maturação nuclear de oócitos préovulatórios é regulada por fatores presentes no fluido folicular, pela interação dos oócitos e células foliculares, bem como por fatores endócrinos, tais como as gonadotrofinas (KIM et al., 2008). Oócitos provenientes de folículos pré-antrais e antrais iniciais adquirem capacidade de quebra da vesícula germinativa apenas quando atingem um determinado diâmetro de acordo com a espécie (maior que $75 \mu \mathrm{m}$ para camundongos e maior que $110 \mu$ m para ruminantes) (EPPIG e SCHROEDER, 1989; FAIR et al., 1995; ANGUITA et al., 2007).

A maturação citoplasmática pode ser considerada como o conjunto de processos pelo qual o oócito de mamíferos passa para tornar-se uma célula capaz de ser fecundada e dar suporte ao desenvolvimento embrionário inicial (ANGUITA et al., 2007). Este programa celular pode ser dividido em três eventos principais: mudanças na morfologia e redistribuição das organelas citoplasmáticas; dinâmica dos filamentos do citoesqueleto e maturação molecular. A maturação molecular trata da transcrição, armazenamento e processamento dos RNAm transcritos que serão, posteriormente, traduzidos em proteínas pelos ribossomos. As proteínas derivadas desses RNAm estão envolvidas tanto na maturação quanto nos eventos celulares subsequentes: fertilização, formação de 
pronúcleos e embriogênese inicial, devendo, portanto, ser estocadas até sua utilização. Como o consumo desses transcritos será feito antes da ativação do genoma embrionário, o armazenamento correto deles no citoplasma do oócito é de fundamental importância. Após a retomada da meiose, não haverá mais expressão gênica e, portanto, tudo o que foi produzido durante a fase de crescimento deverá ser metabolizado no momento adequado. As maiores causas de falha na maturação oocitária são o armazenamento, processamento e recrutamento inapropriado do RNAm materno (SIRARD et al., 2001). Esses dois programas celulares precedem a penetração do espermatozoide e a subsequente ativação para fecundação (ROTH e HANSEN, 2005).

O oócito adquire sua capacidade para fecundação e desenvolvimento após um longo período de crescimento. Como já descrito, este processo envolve tanto a síntese de componentes citoplasmáticos como o rearranjo e a redução no número de cromossomos. Estes dois eventos são interligados, e sua cronologia é determinante para assegurar que o oócito atinja a maturação nuclear e a citoplasmática simultaneamente. O desenvolvimento embrionário é diretamente comprometido se a maturação do oócito não for completa (HUNTER, 2000).

Além do exposto, a expansão do cumulus, embora não seja consenso e haja diferenças espécie-específicas, é descrita como um processo crítico e determinante para o desenvolvimento, ovulação e fertilização de oócitos, já que oócitos cuja maturação não está associada com a expansão do cumulus têm potencial limitado para a implantação (YEO et al., 2009). Segundo Fulop e colaboradores (2003), a expansão do complexo cumulus oophurus facilita a maturação, a liberação do oócito do ovário, a captura do mesmo pelas fibrilas do oviduto e ainda, a penetração espermática.

Embora na maioria dos oócitos bovinos ocorra maturação nuclear espontânea quando retirados de folículos antrais (SIRARD et al., 1988), as gonadotrofinas são frequentemente adicionadas aos meios de maturação para induzir a maturação citoplasmática e expansão das células do cumulus, além de melhorar o desenvolvimento embrionário (ZUELKE e BRACKETT et al., 1990; IZADYAR et al., 1998).

A expansão das células do cumulus e a maturação do oócito são induzidas pelo pico pré-ovulatório de LH in vivo (DIAZ et al., 2006) e pelo FSH em COCs isolados in vitro (SU et al., 2002). No entanto, a ação do LH na maturação oocitária in vivo parece ser indireta, uma vez que o seu receptor (LHR) tem expressão restrita no folículo ovariano. Em bovinos, o RNAm do LHR não foi detectado em células do cumulus e 
oócitos, mas mostrou-se presente em células da granulosa murais de folículos préovulatórios (VAN TOL et al., 1996), indicando que fatores parácrinos mediadores devem ser liberados por este tipo celular em resposta ao LH para promover a expansão das células do cumulus e a maturação do oócito (PENG et al., 1991; CONTI, 2006). O FSH promove a competência oocitária e é amplamente utilizado em protocolos de maturação in vitro a fim de melhorar a expansão das células do cumulus, a fertilização e o desenvolvimento embrionário inicial (CALDER et al., 2003).

Os folículos terciários jovens, ou seja, aqueles que iniciam a formação do antro expressam receptores para FSH, mas apresentam ausência completa ou poucos receptores para LH nas células da granulosa (EYESTONE; AX, 1984). No entanto, sob a ação do FSH, as células da granulosa dos folículos em crescimento, têm capacidade de aromatizar os andrógenos produzidos pelas células da teca interna, convertendo-os em estrógeno, pela ação da enzima aromatase. Os estrógenos (estradiol) produzidos pelas células da granulosa são então secretados no fluido folicular. À medida que o desenvolvimento folicular prossegue, as células da granulosa se tornam sensíveis à LH, devido ao surgimento, nesta fase, de receptores para este hormônio graças à ação do FSH aliado ao estrógeno secretado pelas células da granulosa. Portanto, o estradiol produzido pelas células da granulosa, sob influência do $\mathrm{FSH}$, é o responsável pela maturação dos receptores de LH nas células da granulosa e, consequentemente, pela resposta do folículo à liberação da onda pré-ovulatória de LH (RICHARDS et al., 1976). A regulação da síntese e secreção de esteróides pelas células da granulosa envolve interações entre fatores sistêmicos, autócrinos e parácrinos, secretados pelas células da teca, granulosa e oócitos (SOUZA et al., 2003).

De acordo com Ireland e Roche (1983), folículos saudáveis e ativos (com secreção de estrógenos) apresentaram grande quantidade de células da granulosa em relação a folículos inativos (sem secreção de estrógenos). Fukui e Ono (1989) encontraram um efeito bastante significativo da adição de células da granulosa ao meio de maturação sobre a produção de blastocistos, assim como já foi comprovado por Hutt et al., (2006), que determinaram a vital importância das células somáticas granulosas, para sustentação e adequado desenvolvimento oocitário.

A expressão de receptores de LH e produção de esteróides pelas células da granulosa são imprescindíveis para o crescimento e capacitação adequados do oócito. Os esteroides produzidos pelas células da granulosa, como o estradiol e progesterona, estão 
altamente relacionados com o crescimento e atresia dos folículos, produzindo também um grande efeito nos oócitos (HAZELEGER et al., 1995). Portanto, pode-se dizer que, durante a capacitação e maturação in vitro, a unidade de funcionamento não é apenas o oócito, mas também, as células do cumulus que estão à sua volta, referindo-se assim como um complexo, denominado cumulus- oócito e as demais células somáticas incluídas no folículo, tais como as da teca e as da granulosa (GANDOLFI et al. 2005).

A cooperação existente entre o oócito e as células somáticas ao seu redor é crucial para a regulação da maturação oocitária e remodelamento da cromatina em oócitos bovinos e para a total competência do oócito em suportar a embriogênese (CAIXETA et al. 2009; TESFAYE et al. 2009).

Além de possuírem funções de suma importância como a produção de esteróides e receptores de LH, as células da granulosa ainda secretam pequenas quantidades de progesterona (imediatamente antes da ovulação) e quantidades suficientes de inibina para inibir o desenvolvimento de folículos vizinhos e impedir a liberação de FSH pela hipófise, além de secretarem outros fatores químicos que mantêm o oócito em bloqueio meiótico. Ao remover o oócito do ambiente folicular, ocorre a ausência desses fatores e os oócitos então reiniciam a meiose. A inibina B é principalmente produzida pelas células da granulosa de folículos antrais pequenos (WELT e SCHNEYER, 2001), enquanto que a inibina A é produzida por folículos dominantes e corpo lúteo (WELT et al., 1999). Richard e Sirard (1996) sugerem que, a partir desses fatores inibitórios produzidos, as células da granulosa, em bovinos, sozinhas são suficientemente competentes para a manutenção do oócito em meiose. Estes fatores estão presentes em maior concentração nos folículos menores, cujo fluido folicular é capaz de reter a meiose durante a incubação in vitro (EMANUELLI et al., 2000).

O desenvolvimento completo do oócito dentro da estrutura folicular exige uma comunicação bi-direcional constante entre o oócito e as células da granulosa. Como citado anteriormente, esta comunicação é realizada através das junções comunicantes tipo gap, que ligam as células da granulosa entre si e ainda estas com o oócito, ou através de comunicações parácrinas (ANDERSON e ALBERTINI, 1976). Estas junções são mantidas ao longo de toda fase de crescimento até pouco antes da retomada da meiose, quando os processos entre o oócito e as células da granulosa são recolhidos, de forma a impedir a passagem de metabólitos e moléculas informacionais (VANDERHYDEN, 1996). 
É evidente que o oócito, através da secreção de fatores de crescimento parácrinos, desempenha um papel muito importante em relação ao crescimento e diferenciação de folículos ovarianos. Portanto, esta consiste em uma nova área de investigação e ainda há muito a ser explorado, incluindo a identificação de fatores secretados pelos oócitos e a caracterização das funções exatas dos fatores GDF9, BMP15 e moléculas relacionadas (GILCHRIST et al.,2004).

Contudo, o conhecimento acerca dos mecanismos que controlam a maturação e a aquisição da competência oocitária de bovinos ainda estão pouco elucidados. Sabe-se que a comunicação entre o oócito e as células somáticas incluídas no folículo é fundamental para esse processo e que os fatores liberados pelos oócitos melhoram a expansão das células do cumulus, a maturação e a competência de desenvolvimento do oócito (GILCHRIST et al., 2008). No entanto, até o presente momento, as razões para as falhas na aquisição da competência de oócitos de ruminantes in vitro não foram totalmente esclarecidas, mas podem estar relacionadas a alterações nas reações bioquímicas envolvidas no processo meiótico. Portanto, conhecer as particularidades da fisiologia e os fatores específicos secretados pelo oócito que influenciam nos processos acima descritos é fundamental para melhorar os resultados das técnicas de produção in vitro de embriões nas diferentes espécies, demandando mais estudos na área (CHAVES et al., 2010).

Diante do exposto e visto a ampla importância que as células da granulosa exercem sobre o processo de desenvolvimento, maturação e capacitação oocitária durante o desenvolvimento folicular, o melhor entendimento do funcionamento destas, assim como de alguns genes e proteínas relacionados às células da granulosa, tais como o GDF9 e o BMP15, torna-se essencial para otimizar tais processos visando, desta forma, obter maiores índices de eficiência no procedimento de maturação e fertilização in vitro, assim como na produção de blastocistos. Dentro deste cenário, vale ressaltar que os fatores GDF9 e BMP15, membros da superfamília transforming growth factor- $\beta$ (TGF- $\beta$ ) e secretados pelo oócito, parecem ser responsáveis por modificar a multiplicação, função e diferenciação das células da granulosa (YING et al., 2000). 


\subsection{Fatores GDF9 e BMP15 e sua importância sobre o} funcionamento ovariano

Atualmente, existe um interesse generalizado no estudo de fatores parácrinos secretados por oócitos e seu papel na regulação dos processos-chave das células da granulosa. Grande parte desse interesse recente tem se concentrado nos fatores parácrinos pertencentes à superfamília TGF- $\beta$, principalmente em relação ao GDF9 e ao BMP15, visto que estes vêm se mostrado fundamentais para o desenvolvimento, diferenciação folicular e também para a maturação oocitária e ovulação, além de estarem intimamente relacionados à multiplicação, função e diferenciação das células da granulosa (YING et al., 2000). A atuação dos fatores GDF-9 e do BMP15 nos processos citados é evidenciada por defeitos reprodutivos em animais que possuem mutações desses genes (McNATTY et al., 2004) e pela habilidade das formas recombinantes dos mesmos em mimetizar as ações parácrinas do oócito sobre as células da granulosa e do cumulus em condições in vitro (GILCHRIST et al., 2004). O amplo interesse nesses fatores secretados pelo oócito surgiu não só pela necessidade de melhorar a nossa compreensão acerca dos mecanismos fundamentais reguladores da foliculogénese, mas também porque a expressão alterada de alguns destes fatores possuem efeitos profundos sobre a função ovariana e fertilidade (GILCHRIST et al., 2008).

A partir da produção de fatores parácrinos, o oócito também é responsável pela proliferação e função das células da granulosa, além de possuir grande influência no processo de esteroidogênese (VANDERHYDEN, 1996). Esta capacidade regulatória do oócito sobre o crescimento e diferenciação folicular, é alcançada através da síntese e secreção de fatores específicos do oócito, em especial GDF9 e BMP15, os quais atuam nas células da granulosa para modificar sua multiplicação, função e diferenciação, bem como através de contatos físicos diretos que ocorrem na interface oocito-células da granulosa (HUTT e ALBERTINI, 2007). O GDF9 e o BMP15 estão implicados também na foliculogênese (GILCHRIST et al., 2008), esteroidogênese, inibição da luteinização e diferenciação das células do cumulus e da granulosa (GILCHRIST et al., 2006). Desta forma, a foliculogênese pode ser desregulada quando um destes fatores de crescimento está ausente ou inativo (EPPIG, 2001).

Na maioria das espécies, o GDF-9 e o BMP-15 ovarianos são exclusivamente expressos pelo oócito (JUENGEL et al., 2004; SHIMASAKI et al., 2003), embora ambos 
tenham sido detectados por PCR em células da granulosa de folículos antrais em cabras (SILVA et al., 2005). O maior número de investigações acerca do gene GDF9 ocorreu a partir da descoberta de que a deleção do mesmo causa um bloqueio no desenvolvimento de folículos pré-antrais e, consequentemente, leva à infertilidade de camundongos (DONG et al., 1996). Mazerbourg e colaboradores descobriram em 2004 que o GDF9 está envolvido no recrutamento inicial e na progressão de folículos primordiais até o estágio pré-antral. Desta maneira, o GDF9 consiste num fator de crescimento e diferenciação celular que atua nas células somáticas inclusas no folículo de forma parácrina, onde estimula mudanças na morfologia, expressão gênica e produção esteroidogênica. O GDF9 ainda possui um papel essencial no crescimento e atresia folicular, na ovulação, fertilização e reprodução em fêmeas (ELVIN et al., 1999; HAYASHI et al., 1999; ORISAKA et al., 2006). Além do exposto, o GDF-9 foi o primeiro fator oócito-específico que mostrou causar a expansão do cumulus, funcionando assim como um fator de ação parácrina do oócito que regula várias enzimas-chave das células da granulosa importantes para a expansão das células do cumulus, comprovando a importância deste fator na criação de um microambiente ótimo para a aquisição da competência de desenvolvimento do oócito (PANGAS e MATZUK, 2005).

A inativação do gene GDF9 em oócitos de camundongos culminou com a deficiência na expansão do complexo cumulus-oócito (VADERHYDEN et al., 2003). Gui e Joyce (2005), através da redução da expressão gênica do GDF9 pela técnica de RNA de interferência, eliminaram completamente a expansão das células do cumulus, levando a concluir que o GDF9 em camundongos é o único fator permissivo para a expansão dessas células.

A expressão do GDF-9 é detectável a partir do estágio primordial (em ruminantes; BODENSTEINER et al., 1999) ou primário (em camundongos; McGRATH et al., 1995) do desenvolvimento folicular e é essencial para o desenvolvimento de folículos secundários, uma vez que camundongos com deleção do gene mostraram-se inférteis e com desenvolvimento folicular interrompido no estágio primário (DONG et al., 1996). Além disso, o GDF-9 estimulou o crescimento folicular pré-antral de ratas in vivo, provavelmente pela potencialização da proliferação das células da granulosa (VITT et al., 2000ab).

Em estudos envolvendo o desligamento da expressão do GDF9, os oócitos ainda apresentaram desenvolvimento e disposição anormais das organelas citoplasmáticas e 
ausência de apoptose nas células da granulosa (CARABATSOS et al., 1998; SHIMASAKI et al., 2004). Em outros estudos de inativação do GDF9, a foliculogênese foi interrompida ainda no estágio primário de desenvolvimento, culminando com a ausência de formação de folículos maturos, ovulações e, consequentemente, de prenhez (DONG et al., 1996; ELVIN et al., 1999).

O GDF9, majoritariamente expresso e secretado pelo oócito (CHANG et al., 2002), já teve seu RNAm localizado em oócitos bovinos, ovinos (BODENSTEINER et al., 1999) e caprinos (SILVA et al., 2004a). O GDF9 oocitário, além de regular o crescimento e desenvolvimento do folículo em todas as fases da foliculogênese, ainda estimula a expressão de receptores de FSH (FSHR), protege as células contra atresia, promove a proliferação celular, reduz a expressão do receptor de LH (LHR) e afeta a estereoidogênese de células da granulosa (OTSUKA et al, 2011). O efeito biológico do GDF9 só ocorre após sua ligação com o seu receptor específico (VITT et al., 2002; MAZERBOURG et al., 2004).

O GDF9 também controla a expressão de alguns genes nas células da granulosa. A proteína Gremlin teve sua expressão aumentada pelo GDF9 em células da granulosa murinas (PANGAS et al, 2004), assim como como a inibina B (INHB) e a proteína regulatória da esteroidogênese aguda (StAR) ou diminuída como no caso da inibina A (INHA) (MAZERBOURG e HSUEH, 2006). Estudos demonstram também que o GDF9 estimula a secreção basal de estradiol e progesterona pelas células da granulosa de pequenos folículos antrais de ratas (VITT et al., 2000).

Homólogo ao GDF9, o BMP15 já foi encontrado em oócitos de folículos primordiais e primários de diversas espécies. Assim como o GDF9, o mRNA e proteínas do gene BMP15 são encontrados em oócitos durante toda a foliculogênese, com aumento dos níveis de expressão em folículos primários até folículos maturos de camundongos e ratos (revisado por PAULINI, 2010). A proteína BM15 foi primeiramente observada nos oócitos de folículos primários de ovinos (GALLOWAY et al., 2000), humanos (AALTONEN et al., 1999), ratos (JAATINEN et al., 1999) e camundongos (LAITINEN et al., 1998) e em folículos primordiais de pequenos marsupiais (ECKERY et al., 2002). Em caprinos, a presença da BMP15 foi mostrada nos oócitos de todas as categorias foliculares, bem como nas células da granulosa de folículos primários, secundários e antrais (SILVA et al., 2004b). 
A proteína BMP-15, produzida e secretada pelo oócito, também conhecida como fator de crescimento e diferenciação 9B (GDF9B), além de apresentar um significativo papel mitogênico sobre as células da granulosa, ainda contribui positivamente para o desenvolvimento folicular durante as fases iniciais e finais da foliculogênese (OTSUKA et al., 2000; JUENGEL et al., 2004). Trabalhos utilizando a BMP15, por sua vez, também têm verificado seu importante papel na prevenção da atresia em células somáticas foliculares (HUSSEIN et al., 2005; YOSHINO et al., 2006).

A expressão de mRNA do BMP15, assim como no GDF9, não foi observada nos oócitos anteriormente à formação do folículo, sendo detectados apenas em folículos em crescimento, evidenciando a função destes fatores na regulação do desenvolvimento folicular de mamíferos (DUBE et al., 1998; LAITINEN et al., 1998; JUENGEL e McNATTY, 2005). Uma evidência adicional da participação do BMP15 na foliculogênese, é que as proteínas traduzidas por tal gene são liberadas do oócito para a matriz extracelular do cumulus oophurus (GUÉRIPEL et al., 2006).

O BMP15 tem sido considerado um importante regulador do desenvolvimento folicular e da ovulação em mamíferos (GALLOWAY et al., 2000; SHIMASAKI et al., 2004; JUENGEL et al., 2004; McNATTY et al., 2005a). De fato, estudos com imunização passiva contra a BMP15 revelaram que ovelhas imunizadas apresentavam quantidade reduzida de folículos em estágios superiores ao primário e ainda baixa taxa de formação de antro e ovulação (JUENGEL et al., 2002a, b). A proteína BMP15 ainda estimula a expressão do fator de crescimento epidermal (EGF) nas células do cúmulus de camundongas (YOSHINO et al., 2006).

O BMP15 possui como alvo principal as células da granulosa e, além disso, o estímulo da proliferação dessas células e a regulação diferencial dos hormônios esteróides, são apontados como sua primeira função biológica. Dessa forma, o fator BMP15, é considerado como o principal fator de crescimento responsável por coordenar a proliferação das células da granulosa e diferenciação da fisiologia reprodutiva normal (OTSUKA et al., 2000). Assim como o GDF9, o mRNA do BMP15 e suas proteínas, também podem estar relacionados com a expansão das células do cumulus, visto que têm suas expressões aumentadas no momento dessa expansão (LI et al., 2008a;b). Visto que a BMP-15 e o GDF-9 são secretados pelo oócito durante todo o crescimento folicular, evidências sugerem que estes dois fatores de crescimento interagem entre si, atuando nas células-alvo como um único complexo funcional (JUENGEL e McNATTY, 2005). 
A expressão gênica dos fatores parácrinos GDF9 e BMP15 ocorre quando o mRNA é transcrito a partir da molécula de DNA para, em seguida, ser traduzido em proteína. Os fatores membros da superfamília TGF-ß3 são sintetizados no interior do retículo endoplasmático rugoso como precursores pré-peptídicos, formados pela próregião e o domínio bioativo maduro (CHANG et al., 2002).

A sequência de aminoácidos constituintes do fator GDF9 contém quatro sítios ligados à glicolização, um deles situado na região madura, enquanto que o fator BMP15 é provido de cinco sítios de glicolização, sendo que dois destes são situados na região madura (MCPHERRON e LEE, 1993; MASSAGUÉ et al., 1994; McGRATH et al., 1995; DUBE et al., 1998). Estudos in vitro realizados com os fatores GDF9 e BMP15 demonstram que os sítios de glicolisações são fundamentais para reconhecimento desses fatores por seus receptores específicos e, consequentemente, para sua bioatividade (SHIMASAKI et al., 2004).

Experimentos realizados in vitro mostram que o efeito fisiológico do GDF9 e do BMP15 depende da espécie em questão, visto que a fisiologia e morfologia reprodutiva entre as diferentes espécies é muito variável (McNATTY et al., 2005a;b). Entretanto, muitos estudos indicam que o GDF9 e o BMP15 possuem papéis críticos na arquitetura ovariana, sendo essenciais para o desenvolvimento folicular e interferindo consideravelmente na função, crescimento e formação das células da granulosa e da teca durante o crescimento folicular (VITT e HSUEH, 2001; WU e MATZUK, 2002). Portanto, mutações, inativações ou deleções nestes genes relacionam-se diretamente com a infertilidade, fato este que têm despertado ampla atenção destes fatores e de seus respectivos receptores no meio científico (ELVIN et al., 2000; McNATTY et al., 2003; Di PASQUALE et al., 2004; SHIMASAK et al., 2004). A superexpressão dos fatores GDF9 e BMP15 em oócitos de camundongos, ainda podem conduzir a hipofertilidade das fêmeas, com reduzidos tamanhos de ninhadas e ciclos estrais prolongados (LAN et al., 2003). Assim, a manutenção de níveis precisos de expressão do BMP15 e GDF9 nos oócitos, assim como de seus receptores nas células da granulosa, é essencial para a eficiência da fertilidade e adequado desenvolvimento folicular. 


\subsection{Receptores específicos e vias de sinalização dos fatores GDF9 e} BMP15

A interação que ocorre entre os fatores parácrinos GDF9 e BMP15 e as célulasalvo, ou seja, as células somáticas (células da granulosa e do cumulus) que circundam o oócito de mamíferos, é realizada via receptores de membrana específicos da superfamília TGF- $\beta$. Tais receptores são subdivididos em duas subclasses: os receptores tipo I, que incluem sete receptores (ALK1a7); e os receptores tipo II, que incluem cinco receptores (Act RII, Act RIIB, AMHRII, BMPRII e TGF $\beta$ RII).

Para agir nas células adjacentes ao oócito, o GDF9 se liga ao receptor tipo I TGF $\beta$ (ALK5) (MOORE et al., 2003; MAZERBOURG et al., 2004) e ao BMPRII (VITT et al., 2002) enquanto que o BMP15 se liga ao receptor BMP tipo IB (ALK6) e ao BMPRII, Quando unidos aos seus ligantes específicos, estes agem como fatores de crescimento conjuntos trazendo a tona dois receptores do tipo I e dois do tipo II, num complexo heterotetramétrico (FRANZEN et al., 1993). Neste complexo, os receptores do tipo II (BMPRII) exercem a função de ativar os receptores do tipo I (ALK6 e ALK5) através da fosforilação de uma região regulatória intercelular. O receptor tipo I, uma vez ativado, fosforila as proteínas Smad específicas que, por sua vez, propagam o sinal até o núcleo da célula (PAULINI, 2010). As proteínas Smad específicas (R-Smad), ativadas pela fosforilação catalisada pelos dos receptores do tipo I, incluem Smad 1, 2, 3, 5 e 8. Uma vez ativada, as moléculas R-Smad interagem com outra molécula Smad, denominada Smad 4, que consiste em um parceiro comum para todos os R-Smad e é conhecida como Smad comum (Co-Smad). Esse complexo Smad / Co-Smad (Smad4) é que, por fim, se transloca ao núcleo celular a fim de interagir com os fatores de transcrição específicos que regulam a expressão de genes alvo (LAGNA et al., 1996; NISHIMURA et al., 1998) (Figura 4).

O fator parácrino BMP15 utiliza um caminho mais clássico de transdução de sinal, unindo-se à seus receptores BMPRII e ALK6 e, posteriormente, ativando os Smads 1, 5 e 8 (MOORE et al., 2003; SHIMASAKI et al., 2004), enquanto que o GDF9 utiliza um caminho de sinalização via TGF $\beta$ - activina, ligando-se à seus receptores BMPRII e ALK5 e, posteriormente, ativando as Smads 2 e 3 (VITT et al., 2002; KAIVO-OJA et al., 2003; ROH et al., 2003; MAZERBOURG et al., 2004) (Figura 4). 


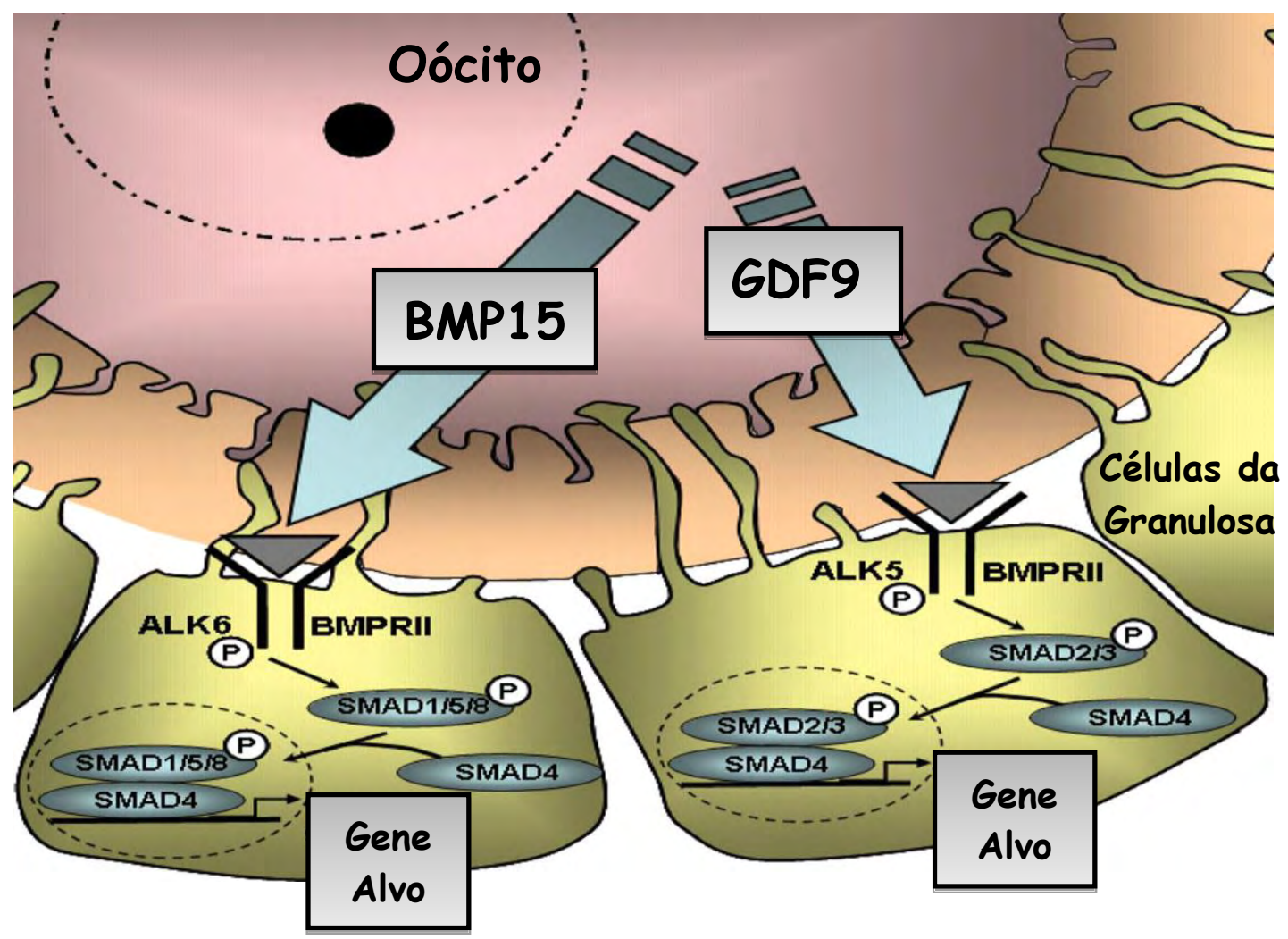

Figura 4. Representação esquemática da sinalização parácrina entre o oócito e as células da granulosa circundantes. Estão representadas as vias de sinalização dos fatores BMP15 e GDF9, derivados do oócito (adaptado de Gilchrist et al., 2008)

Diante do exposto, é possível verificar que o receptor do tipo II (BMPRII), além de ser um receptor comum para os dois importantes fatores parácrinos, o GDF9 e o BMP15, ainda é notável sua maior importância, visto que o receptor do tipo II é responsável por iniciar uma cascata de sinalizações que engloba diversos acontecimentos, iniciando-se a partir da fosforilação e ativação dos receptores do tipo I. O BMPRII, ou receptor de proteína morfogenética óssea tipo II, é expresso nas células da granulosa nos estágios iniciais da foliculogênese, tanto em folículos primordiais de ruminantes como em folículos pré-antrais de roedores, e continuam sendo expressos em todos os estágios subsequentes do desenvolvimento folicular (JUENGEL e McNATTY, 2005). Portanto, o mRNA do BMPRII está presente em todas as categorias foliculares (LIMA et al., 2012), possibilitando desta forma, um estudo mais acurado do papel deste receptor.

Dentro deste cenário, e salientando-se que os fatores membros da superfamília TGF- 3 , em especial o GDF9 e o BMP15, secretados pelo oócito, parecem ser a chave reguladora da organização do ovário, crescimento e diferenciação folicular e do 
desenvolvimento oocitário em vários estádios (YING et al., 2000), além de responsáveis por modificar a multiplicação, função e diferenciação das células da granulosa, optou-se por estudar o gene BMPRII, principal e mais importante receptor desses fatores específicos. Para tanto, uma metodologia de silenciamento gênico do BMPRII em células da granulosa bovinas poderia possibilitar a utilização de tal protocolo como uma ferramenta para investigar seu papel e, consequentemente, constatar a importância funcional da via de sinalização do fator GDF9 e também do BMP15, mediada por esse receptor, sobre a maturação oocitária.

\subsection{Silenciamento Gênico}

O genoma de várias espécies, incluindo o de bovinos, já foi sequenciado com sucesso e tem auxiliado amplamente na investigação da expressão de genes relacionados à embriogênese bovina, em resposta a diferentes condições de cultivo e tratamentos distintos. Apesar disso, a função de um grande número de genes relacionados à embriogênese em mamíferos ainda não foi investigada (NGANVONGPANIT et al., 2006).

Experimentos de perda de função vêm sendo utilizados com o intuito de impedir que o gene estudado resulte na proteína por ele codificada e, assim, podem ser analisadas as consequências ou o fenótipo decorrente desta inibição. Abordagens que procedem do genótipo para o fenótipo são chamadas de genética reversa, tendo como técnica mais amplamente utilizada o knock-out de genes específicos (BARBOSA e LIN, 2004).

O método de knock-out é considerado bastante eficaz e poderoso para identificar funções tecido-específicas de um determinado gene, embora seja um método bastante laborioso (NGANVONGPANIT et al., 2006), com custos elevados, necessitando de uma infraestrutura adequada para produção e manutenção dos organismos geneticamente modificados e, em muitos casos, ainda não é informativo pela letalidade que pode ocorrer durante a embriogênese (KURRECK, 2003).

O silenciamento gênico é um termo geral usado para descrever a regulação epigenética da expressão de um gene. Em particular, este termo refere-se à capacidade de uma célula para prevenir a expressão de um determinado gene. O silenciamento de um gene pode ocorrer durante a sua transcrição ou tradução e é frequentemente usado em pesquisas científicas (National Center for Biotechnology Information, 2013). Diversos 
métodos de silenciamento gênico vêm sendo amplamente utilizados a fim de se conhecer mais afundo o papel de genes que possuem grande interesse na pesquisa.

Muitas vezes, o silenciamento gênico é associado com a técnica de knockout de genes, ou seja, quando se pensa no silenciamento de um gene, logo ocorre uma associação com a deleção total de sua expressão, onde este passa a ser eliminado completamente do genoma do organismo em questão. No entanto, as inúmeras técnicas utilizadas para silenciar um gene consistem em uma redução de sua expressão, denominada knockdown, e não em sua deleção do genoma (HOOD, 2004; MOCELLIN e PROVENZANO, 2004). Portanto, o silenciamento gênico é considerado um mecanismo knockdown do gene, uma vez que os métodos utilizados para silenciar genes, tais como RNAi (RNA de interferência), geralmente proporcionam uma redução da expressão de um gene alvo de, aproximadamente, 70\%, não eliminando-a completamente (HOOD, 2004).

Métodos que utilizam o silenciamento gênico ou knockdown são, portanto, muitas vezes considerados melhores e mais eficientes do que os métodos que adotam o knockout, uma vez que permitem aos pesquisadores estudar genes essenciais, não necessitando para isso, removê-los do genoma o que, muitas vezes, pode levar a complicações severas e até mesmo a morte dos indivíduos, além de consistirem em métodos bastante custosos e laboriosos (HOOD, 2004).

Dentro os métodos utilizados para silenciar um gene, ou seja, proporcionar o knockdown deste gene, podem ser citadas as estratégias que impedem a tradução do RNA mensageiro (RNAm), tendo como vantagens a acessibilidade deste à inativação quando comparados aos genes e à facilidade de obtenção em cultura de células, em organismos inteiros ou embriões, independente do estádio de desenvolvimento (BARBOSA e LIN, 2004).

Um dos métodos baseados em RNAm é a utilização de agentes antisense. Os oligonucleotídeos antisense foram descobertos em 1978 por Paul Zamecnik e Stephenson Maria (KOLE et al., 2012). Neste método, os oligonucleótidos antisense, que consistem em fragmentos de ácido nucleico curtos, compostos geralmente por 13 a 25 nucleotídeos, se ligam a moléculas de RNAm alvo complementares na célula e hibridizam (BARBOSA e LIN, 2004; DIAS e STEIN, 2002; KOLE et al., 2012). Uma vez hibridizados, os oligonucleotídeos negativamente carregados são reconhecidos por uma enzima celular, a RNAse $\mathrm{H}$, que cliva especificamente a fita de RNA e, desse modo, degrada o RNAm 
alvo. Outra classe de agentes antisense, ao invés de ativar a RNAse H, inibe a tradução por impedimento estérico ou interferência no splicing do pré-RNA. Esta classe inclui derivados de ácidos nucléicos modificados como os morfolinos (DALLAS; VLASSOV, 2006; KOLE et al., 2012).

Small interfering RNA (siRNA) é uma molécula intermediária em um processo conhecido como RNA interference ou interferência mediada por RNA (RNAi) e vem sendo utilizada para estudar a função de genes específicos. O RNAi, consiste num processo natural usado pelas células para regular a expressão de um determinado gene. Este processo foi descoberto em 1998 por Andrew Fire e Craig Mello, que ganharam o Prêmio Nobel por sua descoberta em 2006 (National Institutes of Health, 2013). O processo de silenciamento gênico a partir da técnica de RNAi, inicialmente começa com a entrada de uma molécula de RNA de fita dupla (dsRNA), o siRNA, no interior da célula, o que desencadeia a via de RNAi (National Institutes of Health, 2013). Os siRNA, correspondem às fitas sense e antisense do RNA-alvo e se associam a proteínas celulares formando um complexo proteico chamado RISC (AGRAWAL et al., 2003), onde uma helicase presente no complexo é responsável por abrir a dupla-fita dos siRNAs, de forma que a fita antisense do duplex guia o complexo até o RNAm alvo. Uma endorribonuclease, também presente no complexo, cliva o referido RNAm, degradando-o (BAULCOMBE, 2002). O dsRNA é muito importante no processo de silenciamento, pois ele é clivado dentro da célula em fragmentos de 21-23 nucleotídeos por uma nuclease conhecida como DICER (enzima homóloga à RNAse III de E.coli), a qual apresenta um domínio de ligação dsRNAs e helicases (DALLAS e VLASSOV, 2006; WILSON e DOUDNA, 2013) (Figura 5).

O silenciamento nesse processo é classificado como pós-transcricional (CORBEAU, 2008), pois o gene é transcrito dentro da célula, mas não consegue ser traduzido devido à sua degradação. Portanto, os dsRNAs correspondentes a regiões transcritas de genes são induzidos ao silenciamento, já nas direcionadas aos introns, o silenciamento é inefetivo (HAMMOND et al., 2001). 


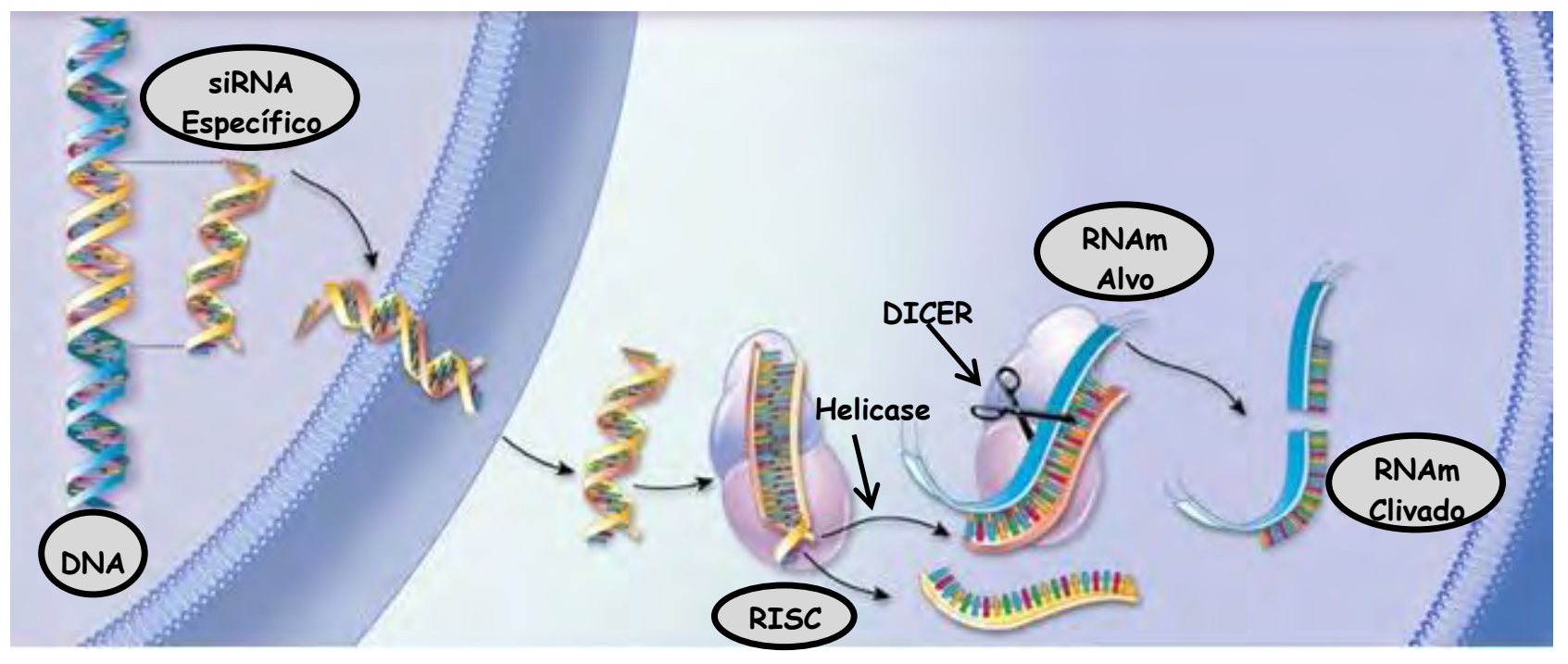

Figura 5: Mecanismo de silenciamento gênico induzido por RNA de interferência. O RNAi pode ser introduzido na célula por transfecção de siRNA ou por vetores (virais ou plasmidiais) (adaptado de www.alnylam.com).

Em 1998, estudos com Caenorhabditis elegans demonstraram que RNAs de dupla-fita (dsRNA) eram capazes de abolir a expressão de um determinado gene com seqüência similar àquele dsRNA (FIRE et al.,1998). Atualmente, siRNAs estão sendo amplamente utilizado para suprimir a expressão de genes específicos e avaliar a função de genes e proteínas celulares. A técnica de RNAi pela introdução de dsRNA já foi utilizada em mamíferos de várias espécies como humanos, camundongos, suínos e bovinos, sendo que neste último, já foi utilizada com a finalidade de suprimir transcritos em oócitos e embriões (NGANVONGPANIT et al., 2006). Em células da granulosa essa técnica também já foi aplicada em diversas espécies (SUGIURA et al, 2009) e, especificamente em bovinos, há o relato de Kobayashi et al (2007), em que o gene para a ciclooxigenase 2 foi silenciado com sucesso.

Vários métodos vêm sendo desenvolvidos com o intuito de transportar o siRNA para o interior da célula, como a utilização de RNAs modificados quimicamente (na região terminal, na ribose ou na estrutura do RNA) ou a utilização de vetores virais ou não virais que expressam o RNA dentro da célula (DALLAS e VLASSOV, 2008).

Apesar da grande eficiência da transfecção dos vetores virais já utilizados, estes apresentam alta toxicidade e por isso, os vetores não virais, como os lipossomas catiônicos, são considerados menos tóxicos e imunogênicos e mais fáceis de manipular quando comparados com os vetores virais (MEVEL et al., 2010). 
A técnica de microinjeção, método mecânico e não viral, vem sendo bastante aplicada em embriões bovinos, pois permite boa repetibilidade e um controle adequado da quantidade de dsRNA introduzido no oócito (PARADIS et al., 2005), podendo ser utilizada em células individuais. No entanto, é ineficiente para introduzir o dsRNA em todos os blastômeros de um embrião, além de demandar muito tempo para a manipulação (GRABAREK et al. 2002) e da necessidade de equipamento de alto custo e pessoal técnico especializado.

Nganvongpanit et al. (2006) descreveram uma perda de 10 a $15 \%$ de oócitos bovinos após a microinjeção e os zigotos não sobreviveram ao procedimento. Danos físicos devido à microinjeção são inevitáveis. $\mathrm{O}$ estudo da meiose e da embriogênese via microinjeção é problemático pela dificuldade técnica, já que os oócitos são difíceis de serem visualizados pela presença das células do cumulus e as pipetas tornam-se rapidamente obstruídas pelas mesmas (AMANAI et al., 2006).

Assim sendo, os lipossomas são considerados o sistema de "entrega" mais conhecido e com maior taxa de sucesso, os quais encapsulam o ácido nucléico a ser transfectado, devido à diferença de cargas elétricas e, neste sistema, o complexo lipídioácido nucléico é internalizado por endocitose (KURRECK, 2003). A transferência de gene mediada por lipossomas catiônicos é bastante efetiva na transfecção de células in vivo e in vitro, apresenta fácil manipulação, alta eficiência na transfecção, baixa toxicidade e reduzido índice de danos celulares e, além disso, ainda não demanda alto investimento e pessoal técnico altamente especializado sendo, portanto, o método mais utilizado para introdução de RNAi em células (OLIVEIRA et al., 2005).

A técnica de RNAi já foi utilizada para estudar a função de genes em cultura primária de células da granulosa em diversas espécies, no entanto, o mesmo protocolo não pode ser utilizado para transfectar o oócito com as suas células do cumulus presentes no seu entorno (SUGIURA et al., 2009), já que há dificuldade na passagem dos reagentes de transfecção pelas células do cumulus para atingir o oócito. Kobayashi e colaboradores (2007) conseguiram silenciar com sucesso o gene para a ciclooxigenase 2 em células da granulosa bovinas, utilizando a técnica de RNAi mediada por moléculas de siRNA.

No entanto, devido à grande quantidade de lipossomas (agentes lipofectores) comerciais disponíveis hoje em dia, assim como a gama de marcadores de transfecção disponibilizados, comerciais ou não, um amplo estudo seguido de diversos testes, adequações e padronizações são requeridos para estabelecer uma metodologia ideal de 
silenciamento gênico pela técnica de RNAi mediada por moléculas de siRNA internalizadas por lipossomas, visto que ainda não existe um protocolo estabelecido para tal. A partir dessa metodologia seria possível a realização da transfecção de células da granulosa a fim de se estudar as subsequentes consequências do knockdown de determinados genes expressos nesse tipo celular. Esta metodologia poderia então ser utilizada como uma ferramenta para investigar, de maneira mais acurada, o papel de diversos genes expressos nas células da granulosa bovinas e que possam ser importantes para o adequado funcionamento do oócito, elucidando assim, os processos morfofisiológicos envolvidos na interação entre as células somáticas e o oócito.

O BMPRII tanto em termos de RNAm quanto de proteína é, sabidamente, expresso em células da granulosa nos folículos de mamíferos em todos as categorias foliculares (WILSON et al., 2001; SOUZA et al., 2002; SILVA et al., 2006; LIMA et al., 2012), possibilitando desta forma, estabelecer in vitro um estudo mais acurado do papel deste receptor. Células da granulosa cultivadas in vitro, mesmo durante o processo de luteinização, continuam expressando os receptores para BMPRII. Portanto, essas células mantêm a total capacidade de reconhecer e responder ao estímulo de fatores de crescimento externos durante o cultivo in vitro em qualquer fase de desenvolvimento folicular (RUA et al., 2009). Foi relatado que a supressão da biossíntese de BMPRII usando a técnica de RNA de interferência (RNAi) bloqueou o efeito estimulatório do GDF9 na proliferação de células da granulosa de ratos (MAZERBOURG e HSUEH, 2006), mas as informações a respeito do seu papel em células da granulosa bovinas ainda são pouco conhecidas.

Desta forma, torna-se essencial a elucidação dos complexos mecanismos de atuação do BMP15 e do GDF9, que pode ser estrategicamente realizada através do silenciamento gênico de seu receptor BMPRII. Diante da ampla importância que os fatores GDF9 e BMP15 exercem sobre a foliculogênese e capacitação oocitária, e sabendo-se que o BMPRII consiste num receptor comum a esses dois fatores parácrinos e ainda apresenta alta afinidade para se ligar a proteínas pertencentes à família TGF- $\beta$, possuindo vital importância para a função das células da granulosa e do oócito, visto que este é considerado a chave para o início das cascatas de sinalizações parácrinas dos fatores oocitários BMP15 e GDF9, através da ativação dos receptores tipo I, este foi selecionado como gene de interesse no presente trabalho, sendo submetido a uma técnica 
inovadora de silenciamento gênico por lipofecção e analisado quanto à sua expressão nas células da granulosa bovinas. 
CAPÍTULO III

\section{Material e Métodos}




\section{MATERIAL E MÉTODOS}

\subsection{Local dos experimentos}

O presente projeto, dividido em dois experimentos sequenciais, foi desenvolvido no Laboratório de Histologia Animal do Departamento de Medicina Veterinária na Faculdade de Zootecnia e Engenharia de Alimentos (FZEA) da Universidade do Estado de São Paulo - USP, Campus de Pirassununga - São Paulo.

\subsection{Obtenção, processamento e cultivo das células da granulosa} bovinas

As células da granulosa (CG) foram obtidas e processadas de acordo com Kobayashi et al (2007). Os ovários foram obtidos de abatedouro comercial, logo após o abate, e imediatamente transportados ao Laboratório de Histologia Animal em solução salina a $30^{\circ} \mathrm{C}$. Ao chegar ao laboratório, os ovários foram lavados em solução salina estéril acrescida de penicilina/estreptomicina (50 UI/mL e $50 \mu \mathrm{g} / \mathrm{mL}$, respectivamente) e, posteriormente, em álcool 70\%. Para obtenção das CG, os folículos ovarianos de 2-6 mm de diâmetro aspirados com auxílio de uma agulha $18 \mathrm{G}$ acoplada a uma seringa de $10 \mathrm{~mL}$. O líquido obtido foi dispensado em uma placa de Petri de $100 \mathrm{~mm}$ para a remoção dos complexos cumulus-oócitos (CCO) sob lupa estereoscópica. O líquido folicular contendo apenas as CG foi transferido para tubos de $15 \mathrm{~mL}$ e lavado duas vezes por centrifugação (20 min a 980 x g) em meio de cultivo celular DMEM completo [44 mM de $\mathrm{NaHCO}_{3}$, FSH $(1 \mu \mathrm{g} / \mathrm{mL})$, ciprofloxacina $(50 \mu \mathrm{g} / \mathrm{mL})$, anfotericina B $(2,5 \mu \mathrm{g} / \mathrm{mL})$ e $5 \%$ de soro fetal bovino (SFB)]. Após a última lavagem, o pellet de células foi resuspendido em $1 \mathrm{~mL}$ de DMEM completo e transferido para uma placa de Petri de $100 \mathrm{~mm}$ de diâmetro, para cultivo em estufa a $38,5^{\circ} \mathrm{C}$ em $5 \%$ de $\mathrm{CO}_{2}$ em ar. Após atingir confluência, aproximadamente às 48 horas de cultivo in vitro, as células foram lavadas duas vezes em PBS livre de cálcio e magnésio e separadas com 0,05\% de tripsina e 0,02\% EDTA em PBS. Após a separação, as células da granulosa foram lavadas duas vezes por centrifugação (20 min 980 x $g$ ) em DMEM, tiveram sua viabilidade estimada com o corante Azul de Tripan e, em seguida, foram semeadas a $5 \times 10^{4}$ células/poço em placas 
Nunc de 4 poços. Após um período de 48 horas de cultivo in vitro, ainda nas placas de 4 poços, as células foram submetidas aos diferentes tratamentos (Figura 6).

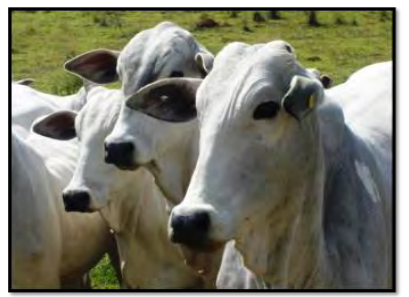

Doadoras

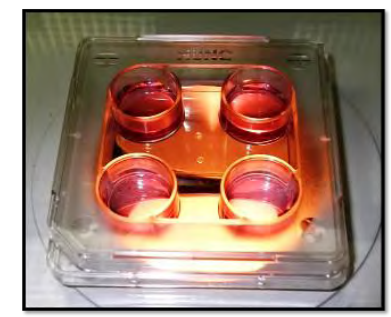

As CG foram separadas

e semeadas a $5 \times 10^{4}$

células/poço em placas de 4 poços.

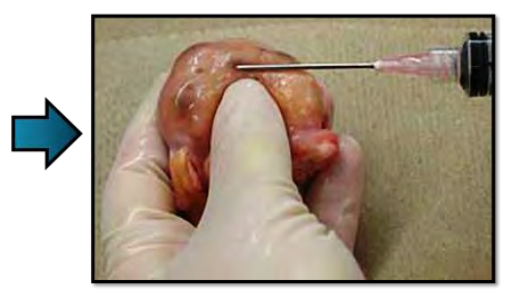

Aspiração folicular

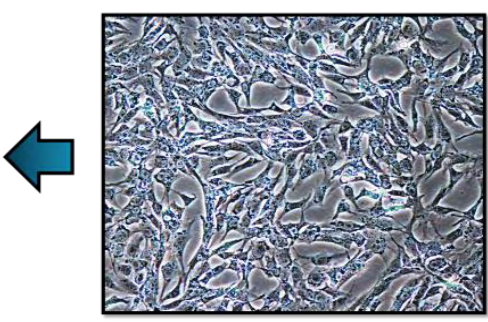

Confluência - Placa Petri de 100 mm

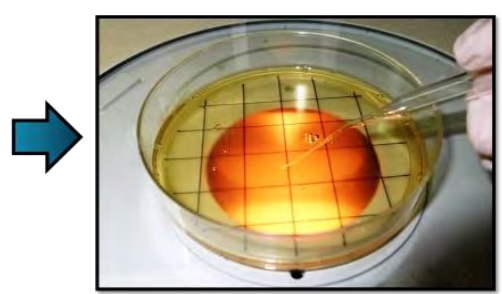

Remoção dos COC's

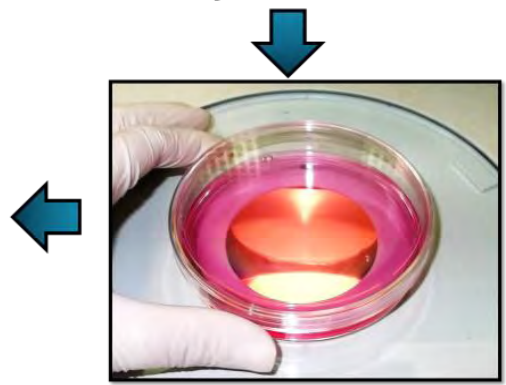

CIV das CG em meio convencional (DMEM Completo) a $38,5^{\circ} \mathrm{C}$ e $5 \%$ de $\mathrm{CO}_{2} \mathrm{em}$ ar.

Figura 6. Representação esquemática da obtenção, processamento e cultivo das células da granulosa bovinas anteriormente à submissão das mesmas aos tratamentos do experimento 1 e 2 .

\subsection{Padronização do cultivo de células da granulosa}

Inicialmente foram realizados testes para o estabelecimento das melhores condições de cultivo celular das células da granulosa. Os testes de padronização realizados seguem descritos a seguir:

A. Cultivo celular em placas de diferentes dimensões (35 a $100 \mathrm{~mm}$ ): Foram testadas placas com 35, 60 e $100 \mathrm{~mm}$ de diâmetro. Como as placas de $100 \mathrm{~mm}$ proporcionam um maior índice de proliferação celular, assim como maior integridade e qualidade das células, esta dimensão de placa foi adotada para os cultivos iniciais de células da granulosa;

B. Diferentes densidades celulares em placas Petri de $100 \mathrm{~mm}$ (50.000 a 200.000 células): Foram testadas três diferentes densidades celulares, de 50.000, 100.000 e 200.000 células 
por placa de $100 \mathrm{~mm}$ (previamente estabelecida no teste A), onde se pôde observar que quanto maior a densidade celular, maior a velocidade de proliferação celular e, consequentemente, menor o tempo para se atingir a confluência desejada, em torno de 80 a 90\% (Figura 7). Diante disso, para cultivo em placas de $100 \mathrm{~mm}$ de diâmetro, estabeleceu-se uma densidade celular de, aproximadamente, 200.000 células viáveis, as quais eram previamente contadas em câmara de Neubauer com o auxílio do corante Azul de Tripan para averiguação da viabilidade celular.
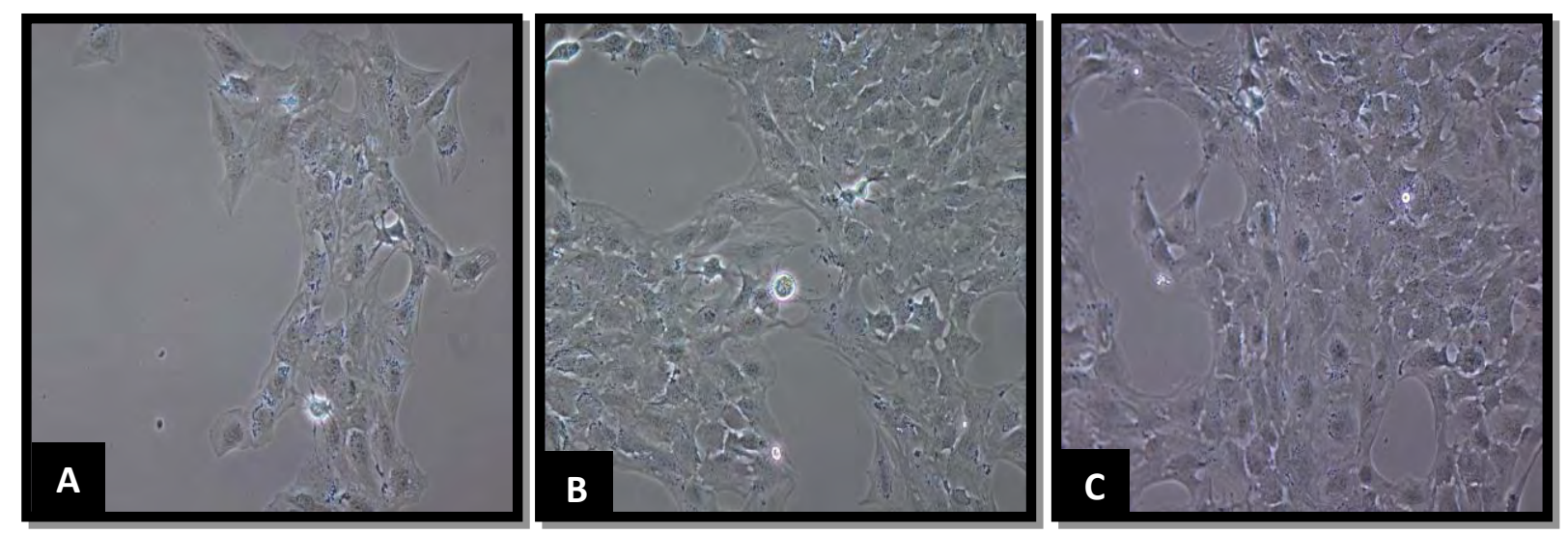

Figura 7. Fotomicrografia de luz (200X) de diferentes densidades celulares (CG) em placas Petri: 50.000 (A), 100.000 (B) e 200.000 células (C).

\section{Diferentes densidades celulares em placas Nunc de 4 poços $(30.000$ a 50.000} células/poço): No presente trabalho, como os diversos tratamentos de silenciamento gênico por lipofecção seriam realizados em placas Nunc de 4 poços, com diâmetro de 10 mm cada, fez-se necessário a realização de testes com diferentes densidades celulares/poço. Foram testadas densidades de 30.000 e de 50.000 células/poço. Assim, notou-se que a densidade de 50.000 células proporcionou uma confluência mais adequada após 24 horas de cultivo, ficando em torno de 80 a $90 \%$, enquanto que a de 30.000 células atingiu cerca de 40 a 50\% (Figura 8). Portanto, a partir desse teste concluiu-se que a densidade mais adequada a receber os tratamentos de lipofecção é a de 50.000 células, visto que para tais tratamentos recomenda-se uma confluência superior a $80 \%$. 

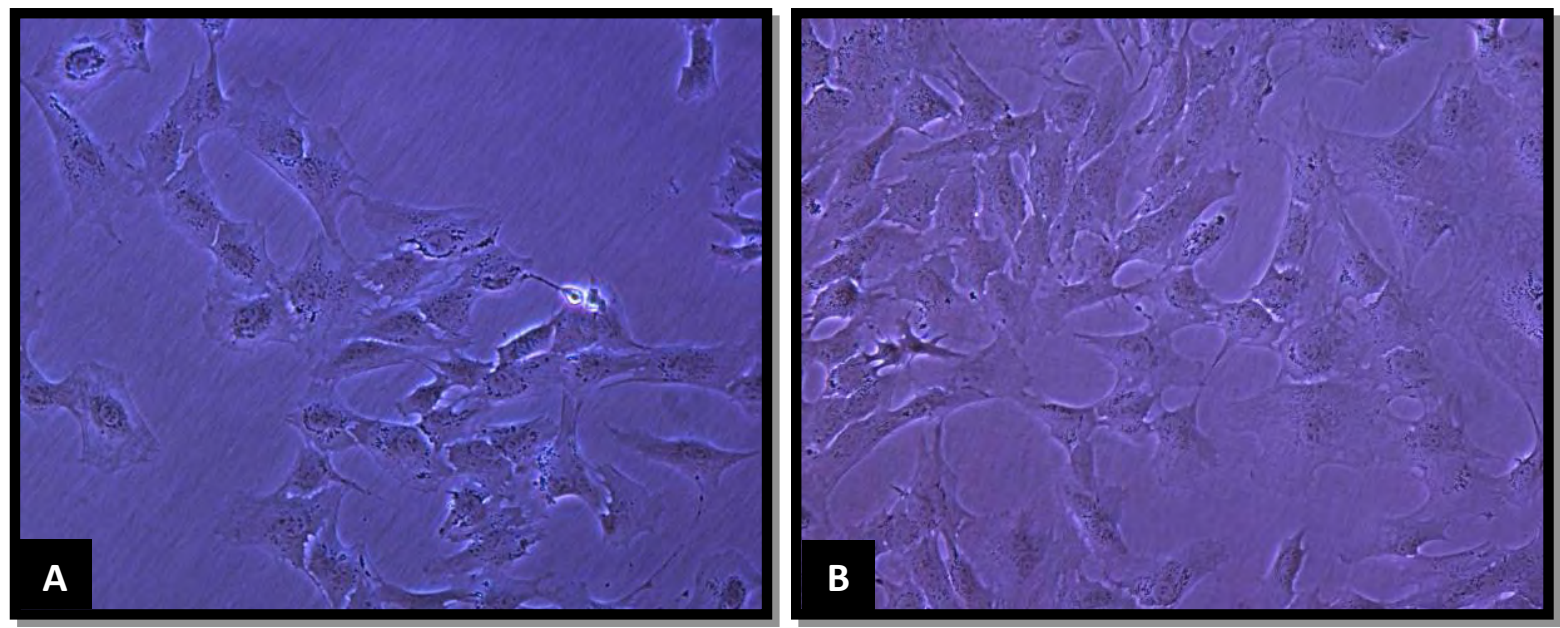

Figura 8. Fotomicrografia de luz (400X) de diferentes densidades celulares (CG) em placas Nunc de 4 poços: 30.000 (A) e 50.000 células (B).

D. Meio de cultivo celular DEMEM (Gibco®) com diferentes tipos de antibiótico: Devido a problemas de contaminação bacteriana detectado no cultivo de CG, foram testados diferentes tipos de antibiótico, em diferentes concentrações, a fim de se erradicar a contaminação. Foram testados os seguintes antibióticos em suas respectivas concentrações: gentamicina $(1 \mu \mathrm{g} / \mathrm{mL}$ ), penincilina/estreptomicina $(50 \mathrm{UI} / \mathrm{mL}$ e 50 $\mu \mathrm{g} / \mathrm{mL}$, respectivamente) e ciprofloxacina $(50 \mathrm{ng} / \mathrm{mL})$. Segundo os testes realizados, o antibiótico que apresentou maior eficiência, ou seja, que foi capaz de eliminar $100 \%$ das bactérias, foi a ciprofloxacina a uma concentração de 50 ng/mL (Figura 9).
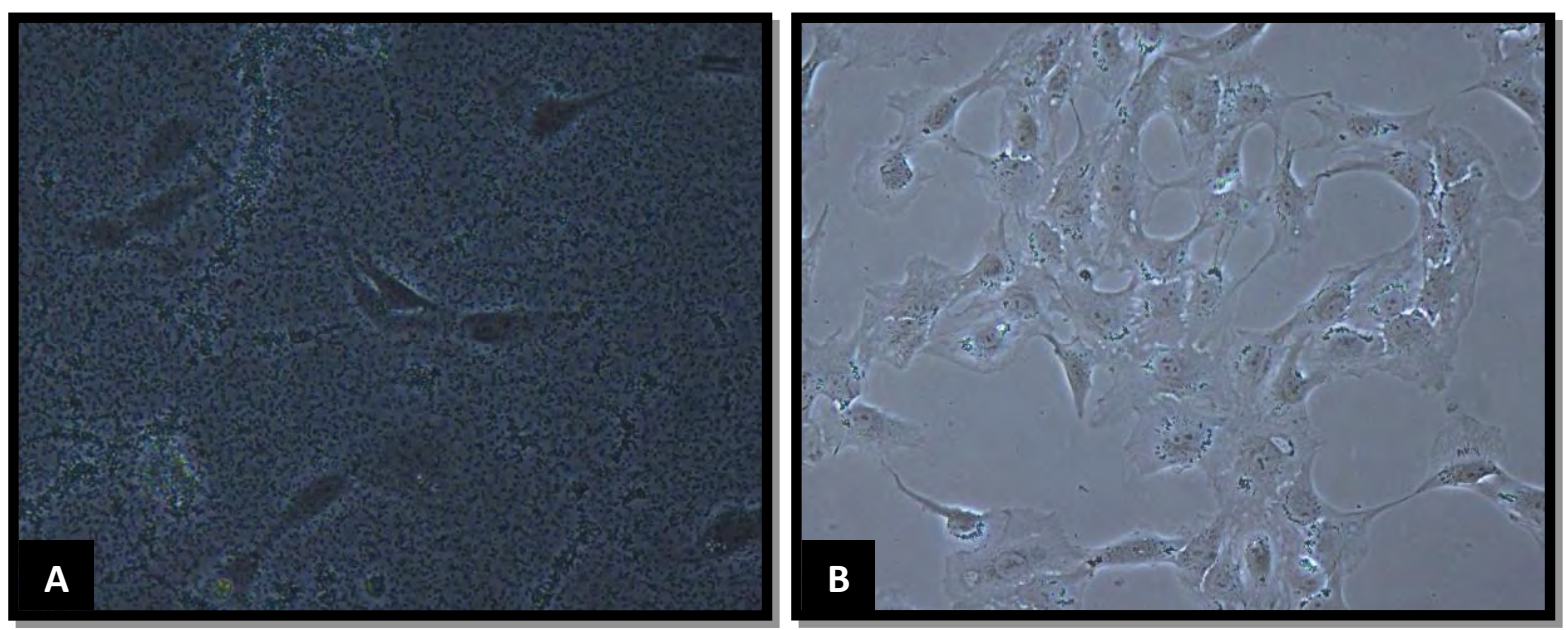

Figura 9. Fotomicrografia de luz (400X) de cultivos de CG na ausência (A) e na presença (B) do antibiótico ciprofloxacina $(50 \mathrm{ng} / \mathrm{mL})$. 
E. Diferentes períodos de cultivo celular (24, 48, 72 e 96 horas): As células da granulosa foram avaliadas e registradas às 24, 48, 72 e 96 horas de cultivo e, diante disso, pôde-se conhecer melhor o comportamento de tais células, tanto quanto à sua proliferação quanto ao seu comportamento morfológico (Figura 10). A partir desse teste foi possível perceber que as CG possuem um elevado grau de proliferação, sendo capazes de confluir uma placa de $100 \mathrm{~mm}$ em menos de 96 horas de cultivo.
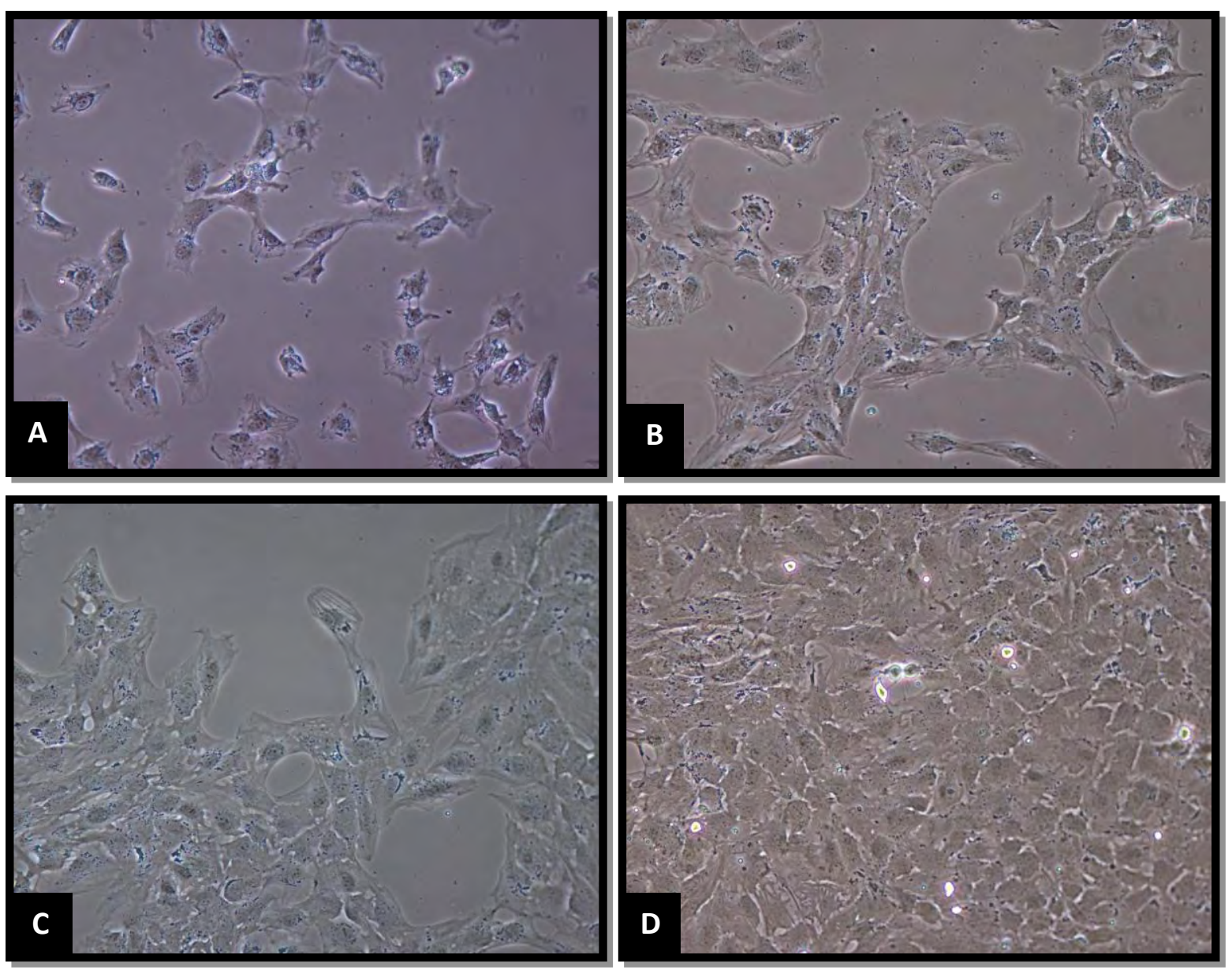

Figura 10. Fotomicrografias de luz (200X) de diferentes períodos de cultivo de CG: 24 horas (A), 48 horas (B), 72 horas (C) e 96 horas (D).

F. Número de passagens suportadas pelo cultivo de CG: Foram realizadas até quatro passagens sucessivas de um mesmo cultivo primário de CG e, a partir da quarta passagem, pôde-se observar que as células já não se apresentavam totalmente íntegras e a qualidade das mesmas também estava visivelmente afetada. Diante disso passou-se a adotar um número máximo de três passagens de um mesmo cultivo de CG. 
Estes testes foram realizados em triplicata para garantir maior confiabilidade da padronização. A partir da realização dos mesmos, foi possível chegar às melhores condições para o cultivo das CG bovinas. 
CAPÍTULO IV

Experimento 1 


\section{EXPERIMENTO 1}

\section{OTIMIZAÇÃO DAS CONDIÇÕES DE LIPOFECÇÃO EM CÉLULAS DA GRANULOSA BOVINAS}

"Optimization of lipofection conditions in bovine granulosa cells" 


\section{RESUMO}

As células da granulosa (CG) são constituintes do ambiente folicular importantes para aquisição da competência oocitária, desempenhando funções como a esteroidogênese, expressão de receptores de LH (LHR), além da síntese de inúmeros transcritos e proteínas essenciais. A lipofecção, utilizada no silenciamento gênico, é um método de transfecção bastante eficiente e pouco agressivo, sendo uma importante ferramenta para investigar a função de genes e proteínas celulares. $\mathrm{O}$ objetivo do presente trabalho foi estabelecer condições de lipofecção em CG bovinas. As CG foram obtidas de ovários bovinos de abatedouro e, após remoção dos complexos cumulus-oócitos, foram cultivadas em meio DMEM com $5 \%$ de SFB a $38,5^{\circ} \mathrm{C}$ e $5 \%$ de $\mathrm{CO}_{2}$ em ar. Após a confluência, as $\mathrm{CG}$ foram separadas e semeadas a $5 \times 10^{4}$ células/poço em placas de 4 poços. Após 48 horas de cultivo, substituiu-se o meio de cultivo pelos lipofectores Lipofectamine ${ }^{\circledR}$ RNAiMAX (1, 2 e $3 \mu \mathrm{l}$; Invitrogen $\left.{ }^{\mathrm{TM}}\right)$ ou Lipofectamine ${ }^{\mathrm{TM}} 2000$ (1, 2 e $3 \mu \mathrm{l}$; Invitrogen $\left.^{\mathrm{TM}}\right)$ e os indicadores de transfecção $\operatorname{siGLO}^{\circledR}(30,50,75$ e $100 \mathrm{nM}$; Thermo Scientific Dharmacon $^{\circledR}$ ) ou plasmídeo transgênico FUGW (100, 200, 300, 400, 600 e 900 nM), em 5 repetições. Como controle foram utilizados grupos de CG em DMEM convencional sem adição das drogas. A eficiência de lipofecção foi verificada visualmente pela proporção subjetiva de CG apresentando fluorescência (indicativo da penetração do agente lipofector com o SiGLO ou FUGW) e pela análise estatística dos valores médios de pixel, captados a partir das fotomicrografias referentes aos diferentes grupos de CG, às 24 e $48 \mathrm{~h}$ de cultivo. A melhor eficiência foi observada às $24 \mathrm{~h}$ de cultivo,. Quanto aos lipofectores, os grupos com Lipofectamine ${ }^{\circledR}$ RNAiMAX + siGLO ou FUGW, para todas as concentrações, apresentaram baixa porcentagem de CG transfectadas (20\%) e nenhuma eficiência de lipofecção, visto que não diferiram estatisticamente do grupo controle; os grupos de Lipofectamine ${ }^{\mathrm{TM}} 2000$ + FUGW, para todas as concentrações, apresentaram uma proporção mediana de CG transfectadas (30-40\%), porém com boa intensidade de fluorescência. Já os grupos Lipofectamine ${ }^{\mathrm{TM}} 2000+$ siGLO $^{\circledR}$ apresentaram a maior eficiência de lipofecção, tanto em intensidade quanto em proporção (80-90\%), otimizadas pelas concentrações $2 \mu \mathrm{l}$ e $100 \mathrm{nM}$, respectivamente, que diferiram significativamente dos demais grupos experimentais $(\mathrm{p}<0,05)$. A partir das melhores condições encontradas às $24 \mathrm{~h}$ de cultivo $\left(2 \mu 1\right.$ de Lipofectamine ${ }^{\mathrm{TM}} 2000+100 \mathrm{nM}$ de siGLO $^{\circledR}$ ) é possível estabelecer uma metodologia de silenciamento gênico por lipofecção 
em CG e a utilização de tal estratégia como ferramenta para o estudo funcional de genes de interesse.

Palavras-chave: Lipofecção; Células da Granulosa; Bovino.

\begin{abstract}
Granulosa cells (GC) are important constituents of the follicular environment for oocyte competence acquisition, performing functions such as steroidogenesis, expression of LH receptors (LHR), and the synthesis of many essential transcripts and proteins. Lipofection, which is used as a means to introduce interfering RNAs for gene silencing, is an efficient and less aggressive transfection method, being an important tool to investigate the role of cellular genes and proteins. The aim of this work was to establish conditions for lipofection in bovine CG. Cells were obtained from slaughterhouse bovine ovaries and after removal of cumulus-oocyte complexes the cells were cultured in DMEM with $5 \% \mathrm{FCS}$ at $38.5^{\circ} \mathrm{C}$ and $5 \% \mathrm{CO}_{2}$ in air. After confluency, the CG were separated and seeded at $5 \times 10^{4}$ cells/well in 4-well dishes. After 48 hours, the medium was replaced with lipofection agents Lipofectamine ${ }^{\circledR} \operatorname{RNAiMAX}(1,2$ and $3 \mu$;

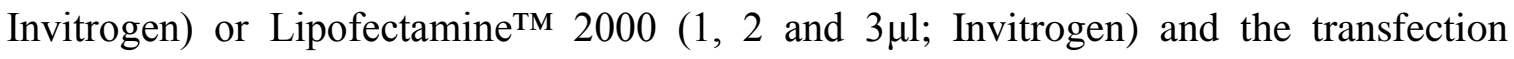
indicators $\mathrm{siGlO}\left(30,50,75\right.$ and $100 \mathrm{nM}$; Thermo Scientific Dharmacon $\left.{ }^{\circledR}\right)$ or FUGW transgenic plasmid $(100,200,300,400,600$ and $900 \mathrm{nM})$, in 5 replicates per treatment. As control, CG groups were cultured in conventional DMEM and not exposed to drugs . The lipofection efficiency was visually verified in a subjective manner considering the proportion fluorescent CG (indicative of penetration of the lipofector with agent siGLO or FUGW) at 24 and $48 \mathrm{~h}$ of culture. The highest efficiency was observed at $24 \mathrm{~h}$ of culture. Regarding lipofection agents, groups with Lipofectamine ${ }^{\circledR}$ RNAiMAX + siGLO or FUGW, at all concentrations, showed a low proportion of transfected CG (20\%); Lipofectamine $^{\mathrm{TM}} 2000+$ FUGW groups, for all concentrations, also showed low percentage of transfected CG (30-40\%), but with good fluorescence intensity. Lipofectamine $^{\mathrm{TM}} 2000+\operatorname{siGLO}{ }^{\circledR}$ groups showed the highest efficiency of lipofection, both in intensity and in proportion (80-90\%). Concentrations were optimized for $2 \mu 1$ and $100 \mathrm{nM}$, respectively. From the best conditions found at $24 \mathrm{~h}$ of culture, with $2 \mu \mathrm{l}$ Lipofectamine $^{\mathrm{TM}} 2000+100 \mathrm{nM}$ siGlo®, it is possible to establish a methodology for
\end{abstract}


gene silencing by lipofection in CG and to use such strategy as a tool for functional analysis of genes of interest.

Keywords: Lipofection; Granulosa Cells; Bovine. 


\subsection{Introdução}

O ovário mamífero é um órgão complexo composto de vários tipos celulares que incluem oócitos (componente germinativo), células da granulosa, da teca, do estroma e do epitélio superficial ovariano (componentes somáticos). Estes tipos celulares estão localizados na região cortical do ovário e, posteriormente, se diferenciam em vários subtipos celulares. As células da granulosa, por exemplo, diferenciam-se em células do cúmulus, murais ou luteais, enquanto que as células da teca desenvolvem-se em camadas internas e externas (ERICKSON e SHIMASAKI, 2003).

O folículo ovariano, por sua vez, consiste na unidade morfofuncional do ovário, onde o componente germinativo (oócito) e os componentes somáticos (células tecais e granulosas) que o circundam são intimamente associados e interdependentes. Dentro de cada folículo, um oócito é circundado de uma ou várias camadas de células da granulosa.

No interior da estrutura folicular, ocorre uma comunicação bidirecional constante entre o oócito e as células da granulosa que o circundam, sendo esta interação essencial para a maturação nuclear e citoplasmática do oócito e, consequentemente, para aquisição da competência oocitária, fertilização e geração de um embrião com alto potencial de desenvolvimento na produção in vitro (TANGHE et al., 2002; FAIR, 2003; GANDOLFI et al. 2005; GILCHRIST et al., 2008).

A interação oócito-células da granulosa in vivo e in vitro, assim como sua influência na qualidade oocitária e embrionária, tem sido alvo de inúmeros estudos, mas muitas questões ainda necessitam ser esclarecidas. Hoje, é sabido que as células da granulosa são um dos constituintes do ambiente folicular de grande importância para a aquisição da competência oocitária, ovulação e fertilização em mamíferos, visto que desempenham funções como a esteroidogênese, expressão de receptores de LH (LHR), secreção de inibina A e B (INHA e INHB), síntese de inúmeros transcritos e proteínas essenciais, além da produção e secreção de fatores químicos necessários para manter o oócito em bloqueio meiótico (RICHARD e SIRARD, 1996).

No entanto, na espécie bovina ainda existe uma escassez de conhecimentos sobre a cooperação existente entre o oócito e as células da granulosa que o circundam, assim como de suas exigências. Assim, um melhor entendimento sobre essa interação, principalmente em relação aos possíveis genes e proteínas envolvidos no processo de capacitação oocitária, torna-se crucial para a adequada regulação da maturação oocitária 
in vitro a fim de possibilitar a total competência do oócito em suportar a embriogênese (CAIXETA et al. 2009; TESFAYE et al. 2009).Compreendendo-se melhor essas interações, os meios de cultivo podem ser aprimorados de forma a minimizar o impacto da perda da unidade folicular durante o cultivo in vitro e, consequentemente, incrementar as taxas de fertilização e produção de embriões in vitro (FIV e PIV).

O silenciamento gênico refere-se à capacidade de uma célula em prevenir a expressão de um determinado gene (NATIONAL CENTER FOR BIOTECHNOLOGY INFORMATION, 2013). Diversos métodos de trasfecção vêm sendo amplamente utilizados a fim de se obter sucesso na técnica de silenciamento gênico e, consequentemente, conhecer mais afundo o papel de genes de interesse.

Apesar da grande eficiência da transfecção dos vetores virais, utilizados para silenciar genes específicos, estes ainda apresentam alta toxicidade e por isso, os vetores não virais, como os lipossomas catiônicos, ou mesmo a técnica de microinjeção, são considerados menos tóxicos e imunogênicos e mais fáceis de manipular quando comparados com os vetores virais (MEVEL et al., 2010).

Os lipossomas, considerados um sistema de "entrega" com elevada taxa de sucesso, encapsulam o ácido nucléico a ser transfectado, devido à diferença de cargas elétricas e, neste sistema, o complexo lipídio-ácido nucléico é internalizado por endocitose (KURRECK, 2003). A transferência de gene mediada por lipossomas catiônicos é bastante efetiva na transfecção de células in vivo e in vitro, apresenta fácil manipulação, alta eficiência na transfecção, baixa toxicidade e reduzido índice de danos celulares e, além disso, não demanda alto investimento e pessoal técnico altamente especializado sendo, portanto, o método mais recomendado para proporcionar o silenciamento de um gene em células (OLIVEIRA et al., 2005).

Sendo assim, a transfecção mediada por lipossomas, também conhecida como lipofecção, bastante utilizada para o silenciamento gênico, consiste em um método bastante eficiente e pouco agressivo, sendo numa importante ferramenta para investigar a função de genes e proteínas celulares.

No entanto, devido à grande quantidade de lipossomas (agentes lipofectores) comerciais disponíveis hoje em dia, assim como a gama de marcadores de transfecção disponibilizados, comerciais ou não, diversos testes, adequações e padronizações são requeridos para estabelecer uma metodologiaeficiente de silenciamento gênico por lipofecção, visto que ainda não existe um protocolo estabelecido para tal. Diante disso, o 
objetivo do presente trabalho foi estabelecer as condições ideais de lipofecção em CG bovinas.

A partir dessa metodologia será possível a realização efetiva da transfecção de células da granulosa bovinas, a fim de se estudar o papel de diversos genes e proteínas expressos nas células da granulosa bovinas e que possam estar relacionados ao adequado funcionamento do oócito, elucidando assim, os processos morfofisiológicos envolvidos na interação entre as células somáticas e o oócito na espécie bovina.

\subsection{Material e Métodos}

\subsubsection{Obtenção das células da granulosa}

Ovários de fêmeas bovina foram coletados de abatedouro comercial, logo após o abate, e transportados ao Laboratório de Histologia Animal em solução salina $(0,9 \%$ de $\mathrm{NaCl}$ ) acrescida dos antibióticos (penincilina/esteptomicina, 10UI e $10 \mu \mathrm{g} / \mathrm{mL}$, respectivamente; Gibco®), à temperatura de $30^{\circ} \mathrm{C}$. No laboratório, os ovários foram lavados em solução salina $(0,9 \%$ de $\mathrm{NaCl})$ estéril aquecida a $37^{\circ} \mathrm{C}$, contendo penicilina/estreptomicina $(50 \mathrm{UI} / \mathrm{mL}$ e $50 \mu \mathrm{g} / \mathrm{mL}$, respectivamente; Gibco®) e, posteriormente, em álcool 70\%. Para obtenção das células da granulosa, os folículos ovarianos de 2 a $6 \mathrm{~mm}$ de diâmetro foram aspirados com auxílio de uma agulha $18 \mathrm{G}$ acoplada a uma seringa de $10 \mathrm{~mL}$. O líquido folicular obtido foi dispensado em uma placa de Petri $(100 \mathrm{~mm})$ para a remoção dos complexos cumulus-oócitos (CCO) com o auxílio de uma lupa estereoscópica. O líquido folicular contendo apenas as células da granulosa (CG) foi transferido para tubos de $15 \mathrm{~mL}$ (TPP) e lavado duas vezes por centrifugação (20 min a 980 x $g$ ) em meio de cultivo celular DMEM (Gibcoß) completo contendo 44mM de $\mathrm{NaHCO}_{3}$, FSH $(1 \mu \mathrm{g} / \mathrm{mL})$, ciprofloxacina $(50 \mu \mathrm{g} / \mathrm{mL}$; SigmaAldrich $\left.{ }^{\circledR}\right)$, anfotericina B $\left(2,5 \mu \mathrm{g} / \mathrm{mL}\right.$; Sigma-Aldrich $\left.{ }^{\circledR}\right)$ e $5 \%$ de soro fetal bovino (SFB; Gibco®). 


\subsubsection{Cultivo das células da granulosa}

Após a última lavagem em meio DMEM (Gibco®) completo, o pellet de células formado foi resuspendido em $1 \mathrm{~mL}$ do mesmo meio e transferido para uma placa de Petri de $100 \mathrm{~mm}$, onde as células foram cultivadas em estufa a $38,5^{\circ} \mathrm{C} \mathrm{em} 5 \%$ de $\mathrm{CO}_{2} \mathrm{em}$ ar. As placas de cultivo celular foram submetidas a trocas diárias de meio, a fim de se remover completamente eventuais células mortas ou restos celulares presentes. Após atingir confluência, cerca de 48 horas após o início do cultivo in vitro, o meio de cultivo foi descartado e as células lavadas duas vezes com PBS livre de cálcio e magnésio e separadas com $5 \mathrm{~mL}$ de uma solução $0,05 \%$ de tripsina e 0,02\% EDTA (Gibcoß) em PBS. Após a separação, as células da granulosa foram lavadas duas vezes por centrifugação (20 min 980x g) em DMEM completo. Posteriormente à última lavagem, as células foram submetidas ao processo de contagem em câmara de Neubauer e tiveram sua viabilidade estimada pelo uso do corante Azul de Tripan 0,4\% (Gibco®). Em seguida, as CG foram semeadas a $5 \times 10^{4}$ células/poço em placas Nunc de 4 poços e cultivadas in vitro a $38,5^{\circ} \mathrm{C}$ e $5 \%$ de $\mathrm{CO}_{2} \mathrm{em}$ ar.

\subsubsection{Transfecção mediada por lipossomas (lipofecção) das células da granulosa}

Após 48 horas de cultivo in vitro, quando a confluência já estava adequada para receber os tratamentos de lipofecção, em torno de 80 a $90 \%$, o meio de cultivo foi descartado e as células lavadas com DMEM (Gibcoß) sem aditivos para a total remoção de traços de antibiótico, fungicida e SFB, visto que estes aditivos diminuem a eficiência da lipofecção. Após a lavagem, os grupos de CG foram tratadas com os agentes lipofectores Lipofectamine ${ }^{\circledR}$ RNAiMAX (1, 2 e $3 \mu$; Invitrogen $\left.^{\mathrm{TM}}\right)$ ou Lipofectamine ${ }^{\mathrm{TM}}$ $2000\left(1,2\right.$ e $3 \mu \mathrm{l}$; Invitrogen $\left.{ }^{\mathrm{TM}}\right)$ e os indicadores de transfecção $\operatorname{siGLO}^{\circledR}(30,50,75$ e 100 nM; Thermo Scientific Dharmacon ${ }^{\circledR}$ ) ou plasmídeo transgênico FUGW confeccionado em laboratório (300, 600 e $900 \mathrm{nM})$, sendo estes últimos responsáveis por determinar a eficiência da técnica de lipofecção através da emissão de um sinal verde quando observado por microscopia de epifluorescência. Em tubos de $0,2 \mathrm{~mL}$, foram preparadas as soluções $A$ e $B$ de transfecção designadas a cada poço (tratamento). A solução $A$ continha os indicadores de transfecção (siGLO ${ }^{\circledR}$ ou FUGW), em suas respectivas quantidades, 
diluídos em $50 \mu \mathrm{L}$ de meio Opti-MEM® (Gibco®). A solução $B$ continha os agentes lipofectores (Lipofectamine ${ }^{\circledR}$ RNAiMAX ou Lipofectamine ${ }^{\mathrm{TM}} 2000$ ), em suas respectivas quantidades, também diluídos em $50 \mu \mathrm{L}$ de meio Opti-MEM®. Após 5 minutos de incubação, separadamente, à temperatura ambiente, a solução $A$ foi adicionada à solução $B$. A solução final foi incubada por um período de 25 minutos à temperatura ambiente, permitindo a formação dos complexos. Posteriormente, os $100 \mu \mathrm{L}$ da solução final foram adicionados a cada poço (tratamento). As placas foram então cultivadas em estufa a $38,5^{\circ} \mathrm{C}$ em $5 \%$ de $\mathrm{CO}_{2}$ em ar por um período de 24 ou 48 horas. Após esses períodos de incubação, as células foram avaliadas quanto à eficiência de lipofecção. Como controle, foram utilizados grupos de CG não expostos às drogas e cultivadas em meio convencional DMEM completo, a fim de averiguar possíveis efeitos dos diferentes meios sobre o cultivo de CG. Foram realizadas cinco repetições de cada tratamento. Abaixo se encontra uma representação esquemática do procedimento de lipofecção em cultivo primário de CG bovinas (Figura 11).

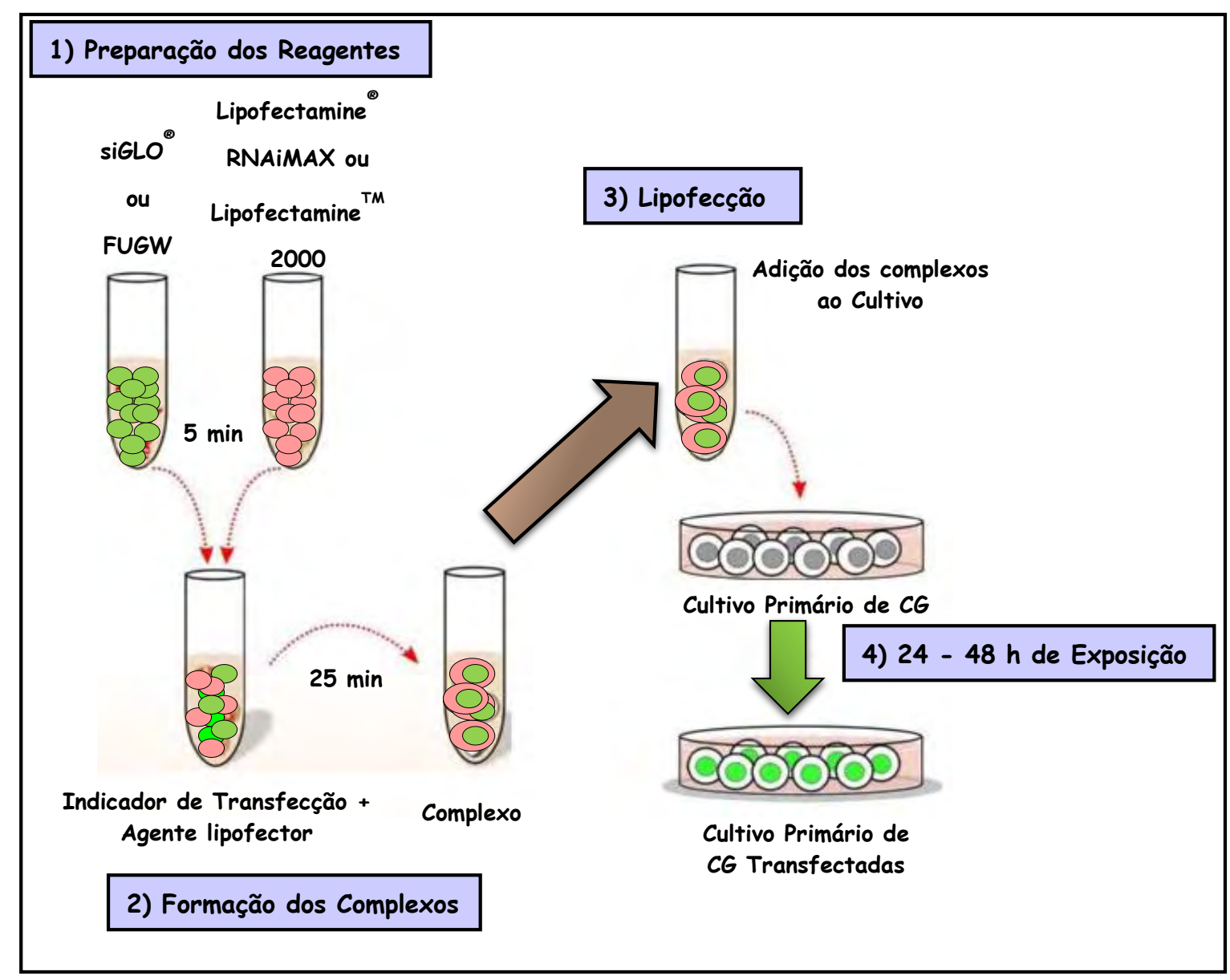

Figura 11. Representação esquemática do procedimento de lipofecção em cultivo primário de CG bovinas. 


\subsubsection{Avaliação visual da eficiência de lipofecção}

A eficiência de lipofecção foi inicialmente verificada visualmente pela proporção subjetiva de CG apresentando fluorescência (indicativo da penetração dos agentes lipofectores Lipofectamine ${ }^{\circledR}$ RNAiMAX ou Lipofectamine ${ }^{\mathrm{TM}} 2000$ com os marcadores SiGLO ou FUGW) e por sua intensidade, às 24 e 48 h de cultivo com as drogas, através de microscopia de epifluorescência. Para averiguar o melhor tempo de exposição dos grupos de $\mathrm{CG}$ aos reagentes de lipofecção, os diferentes grupos foram analisados visualmente quanto à integridade do cultivo e proporção de células degeneradas.

\subsubsection{Captura das imagens e análise quantitativa dos pixels}

A captura das imagens de todos os grupos experimentais de CG foi efetuada com uma câmera digital (Nikon®) acoplada a um microscópio invertido epifluorescência. As fotomicrografias foram obtidas em aumentos de 200 e 400 vezes no formato JPEG (Join Photographic Experts Group). Foram capturadas pelo menos cinco imagens de cada tratamento. As fotomicrografias foram transferidas para um microcomputador equipado com software para edição e mensuração (Image ${ }^{\circledR}$ ), onde foi realizada uma análise quantitativa das células apresentando fluorescência, a partir da quantificação dos pixels captados em cada imagem.

\subsubsection{Análise Estatística}

As médias das quantificações de pixels captados a partir das fotomicrografias, referentes às cinco repetições de cada tratamento, foram aferidas no programa ImageJ® e, a partir dessas, foi possível efetuar a análise estatística. As médias geradas pelo programa foram analisadas estatisticamente com o auxílio do programa GraphPad Prism® versão 5.0. Primeiramente, empregou-se o teste One-wey ANOVA, seguido de teste de Dunnett, para análise das médias de pixels dos diferentes tratamentos experimentais e comparação com os grupos controles. Nos grupos que apresentaram diferença significativa quando comparados aos controles, foi realizada uma nova análise estatística, empregando-se One-way ANOVA, seguido de teste de Tukey, a fim de eleger o grupo experimental que 
proporcionou melhor eficiência de lipofecção. Para todas as análises foi considerando um nível de 5\% de significância $(\mathrm{p}<0,05)$.

\subsection{Resultados}

\subsection{Avaliação do tempo de exposição}

Para a averiguação do melhor tempo de exposição das CG aos reagentes de lipofecção, os diferentes grupos de CG foram analisados visualmente quanto à integridade do cultivo e através do corante Azul de Tripan para determinar a proporção de células degeneradas. A melhor eficiência da técnica foi observada às 24 horas de cultivo, visto que às 48 horas as células já se encontravam bastante degradadas (Figura 12).
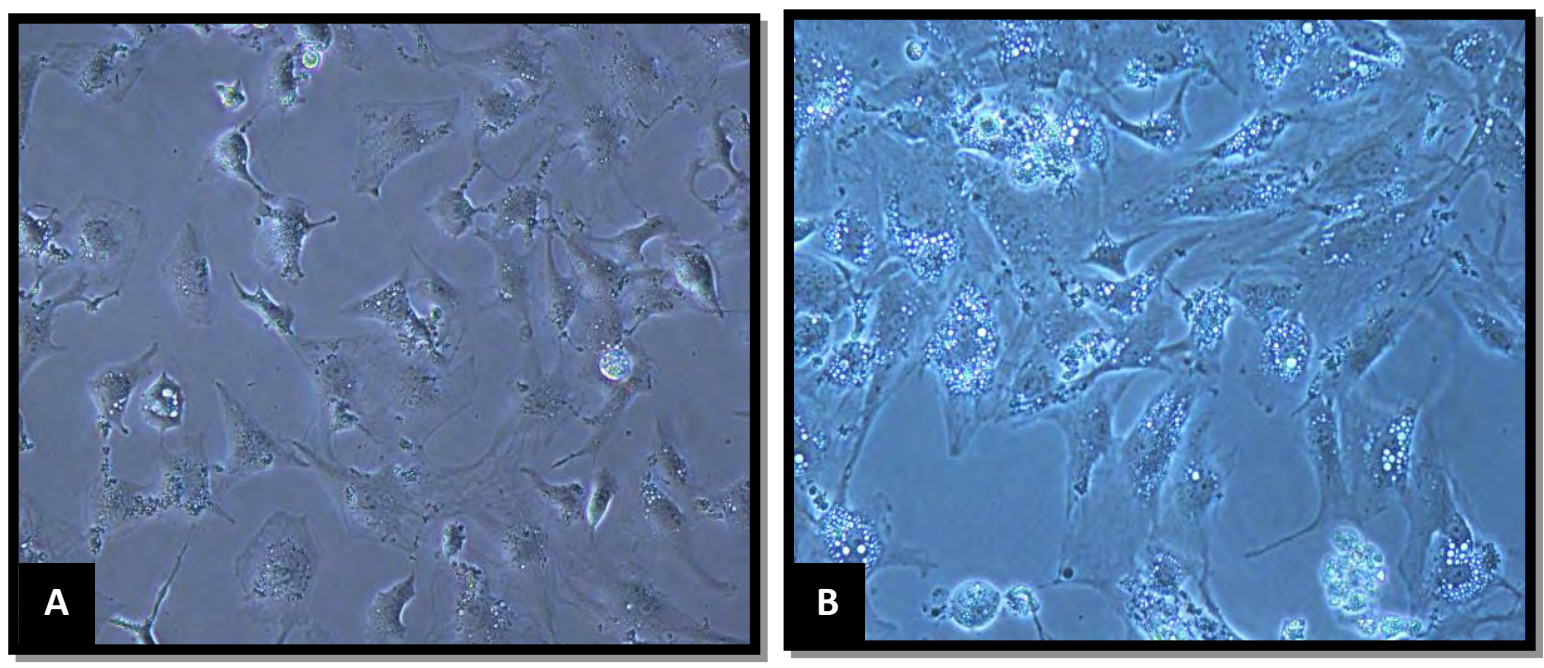

Figura 12. Fotomicrografias de luz normal (400X) dos cultivos de CG submetidas a 24 horas (A) e 48 horas de lipofecção (B).

\subsubsection{Avaliação da eficiência de lipofecção}

\subsubsection{Lipofectamine ${ }^{\circledR}$ RNAiMAX}

Os grupos de CG submetidos à exposição de Lipofectamine $^{\circledR}$ RNAiMAX + Plasmídeo FUGW (Figura 13) ou siGLO (Figura 14), para todas as concentações, 
apresentaram visualmente uma baixa proporção de CG transfectadas (10\%), ou seja, de células fluorescentes. Em relação à quantidade de pixels captados das fotomicrografias, nenhum dos grupos expostos ao agente Lipofectamine RNAiMAX diferiu estatisticamente dos grupos controles de CG ( $\mathrm{p}>0,05)$ (Tabela 1 e Figura 15).

Os grupos experimentais submetidos à exposição de $1 \mu 1$ de Lipofectamine RNAiMAX $^{\circledR}$ não apresentaram fluorescência alguma, enquanto os submetidos a $3 \mu 1$ apresentaram uma elevada proporção de células degradadas. Assim, foram analisados estatisticamente apenas os grupos expostos a $2 \mu \mathrm{L}$ desse agente lipofector.

Quanto aos indicadores de transfecção, o plasmídeo transgênico FUGW, confeccionado em laboratório, quando adicionado na quantidade de $300 \mathrm{nM}$ aos grupos de CG expostos a $2 \mu 1$ de Lipofectamine $^{\circledR}$ RNAiMAX, também não apresentou fluorescência alguma, enquanto que a adição das quantidades de 600 e $900 \mathrm{nM}$ deste mesmo marcador, proporcionaram baixa fluorescência das células, indicando ineficiência no processo de transfecção. Diante da ausência de fluorescência nos grupos de CG contendo $300 \mathrm{nM}$ de FUGW + $2 \mu 1$ de Lipofectamine ${ }^{\circledR}$ RNAiMAX, esses não foram inclusos na análise estatística, sendo analisados apenas os grupos expostos a 600 e 900 nM do marcador. Já, o indicador de transfecção siGLO ${ }^{\circledR}$, para as quantidades de 50, 75 e $100 \mathrm{nM}$, adicionadas aos grupos de CG expostos a $2 \mu \mathrm{L}$ de Lipofectamine ${ }^{\circledR}$ RNAiMAX, apresentaram uma fluorescência bastante reduzida, no entanto, possíveis de serem analisadas estatisticamente, ao contrário da quantidade de $30 \mathrm{nM}$ deste mesmo marcador, que não proporcionou fluorescência nos grupos de CG sendo, portanto, excluído da análise. 

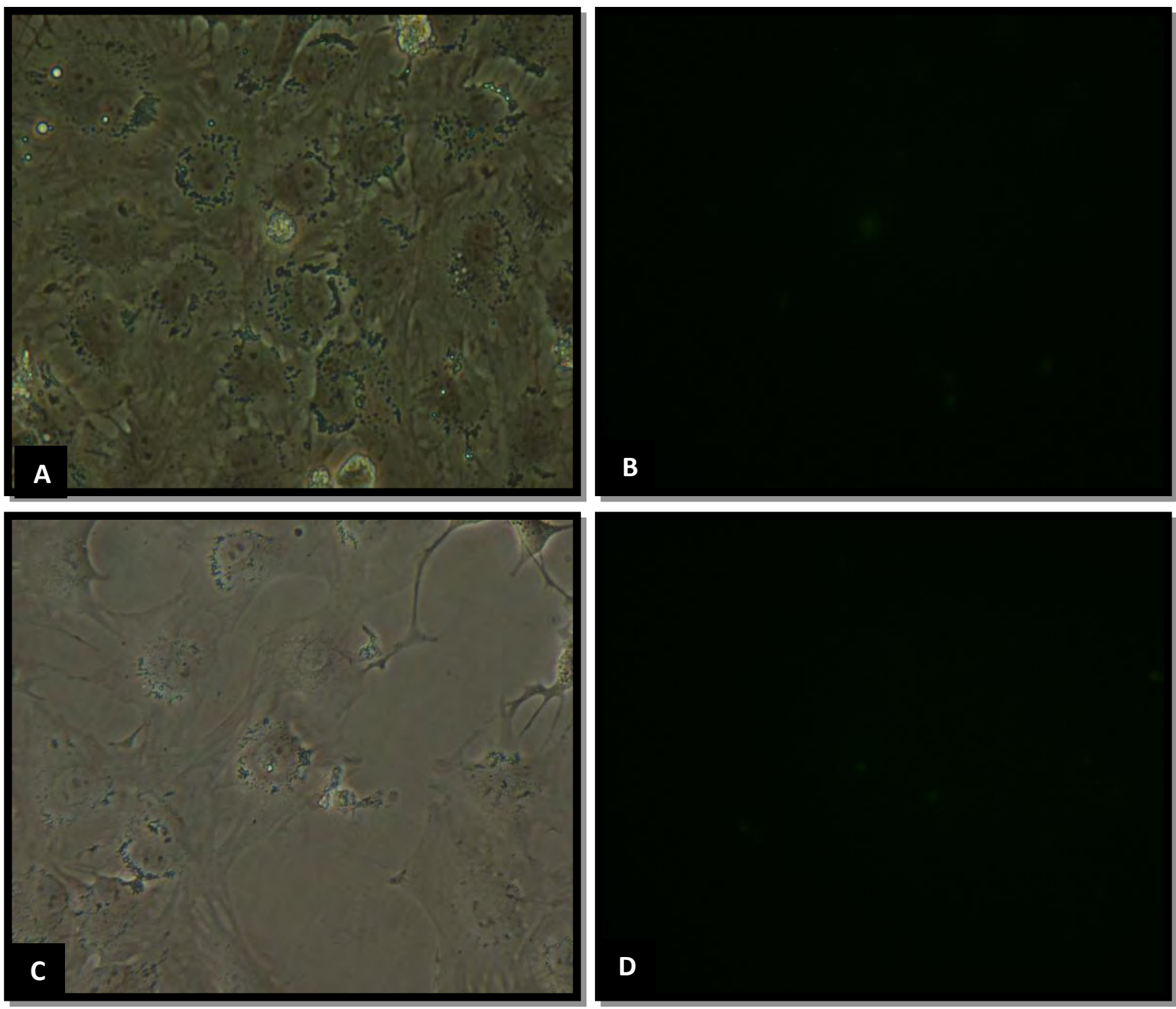

Figura 13. Fotomicrografias (400X) de luz normal (A e C) e de fluorescência (B e D - 400ms) de CG submetidas à lipofecção com o agente lipofector Lipofectamina RNAiMAX e o marcador Plasmídeo FUGW. Estão representadas apenas as concentrações que proporcionaram fluorescência: $2 \mu \mathrm{L}$ de Lipofectamina RNAiMAX e 600 nM do FUGW (A e B); $2 \mu \mathrm{L}$ de Lipofectamina RNAiMAX e 900 nM do FUGW (C e D). 


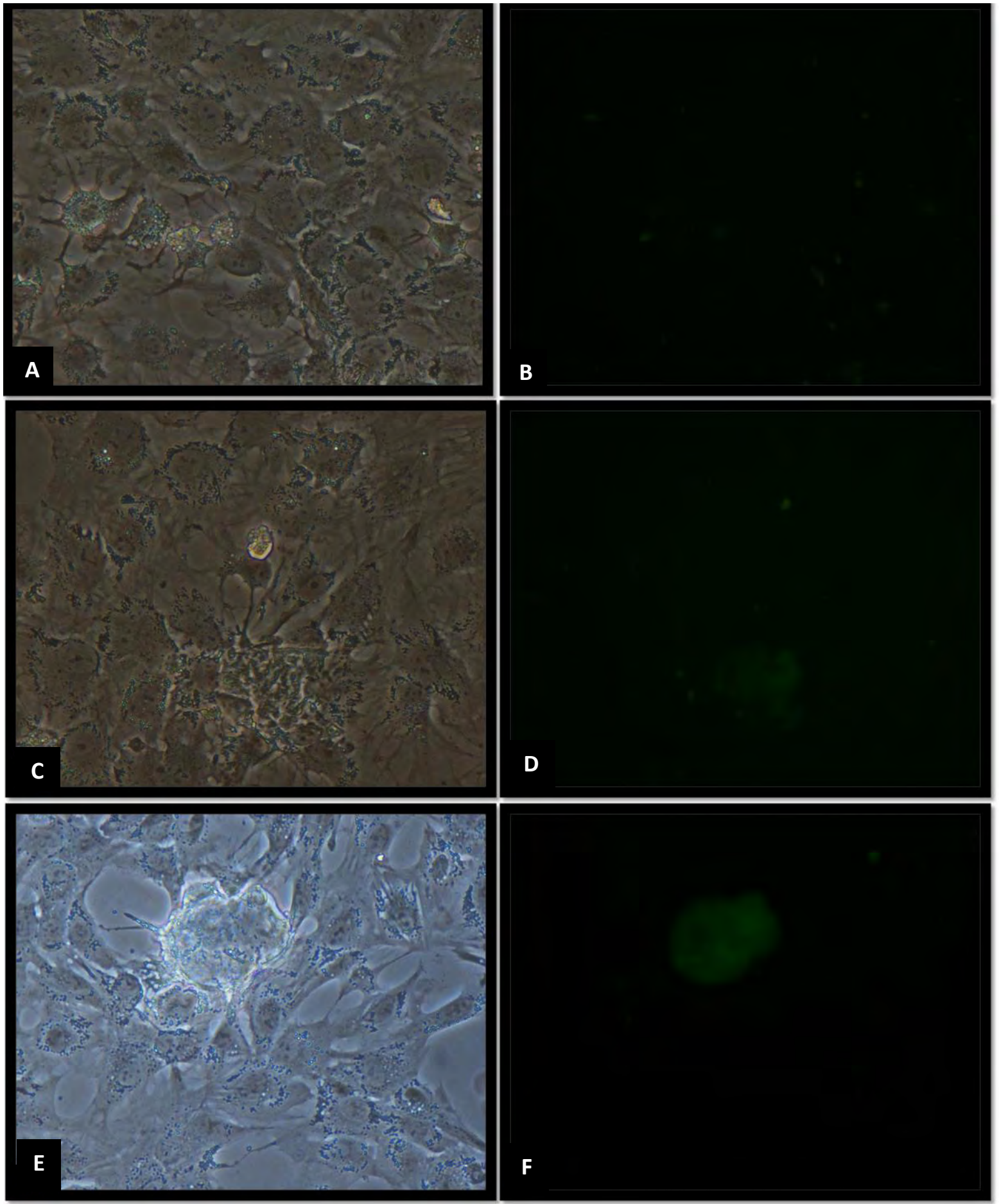

Figura 14. Fotomicrografias (400X) de luz normal (A, C e E) e de fluorescência (B, D e F 400ms) de CG submetidas à lipofecção com o agente lipofector Lipofectamine® RNAiMAX e o marcador siGLO®. Estão representadas apenas as concentrações que proporcionaram fluorescência: $2 \mu \mathrm{L}$ de Lipofectamine ${ }^{\circledR}$ RNAiMAX e $50 \mathrm{nM}$ do siGLO® (A e B); $2 \mu \mathrm{L}$ de Lipofectamine ${ }^{\circledR}$ RNAiMAX e $75 \mathrm{nM}$ do siGLO ${ }^{\circledR}\left(\mathrm{C}\right.$ e D); $2 \mu \mathrm{L}$ de Lipofectamine ${ }^{\circledR}$ RNAiMAX e $100 \mathrm{nM}$ do $\operatorname{siGLO}(\mathrm{E}$ e F). 
Tabela 1. Médias de pixels captados a partir das fotomicrografias, referentes aos diferentes grupos experimentais de CG expostos a $2 \mu 1$ do reagente Lipofectamine RNAiMAX, com seus respectivos desvios padrões.

\begin{tabular}{ccc}
\hline Grupos & Número de Repetições & $\begin{array}{c}\text { Médias } \\
\text { (Pixels) }\end{array}$ \\
\hline RNAiMAX $(2 \mathrm{uL})+$ FUGW $(600 \mathrm{nM})$ & 5 & $688,67( \pm 53,50)$ \\
RNAiMAX $(2 \mathrm{uL})+$ FUGW $(900 \mathrm{nM})$ & 5 & $873,67( \pm 84,23)$ \\
RNAiMAX $(2 \mathrm{uL})+$ siGLO $(50 \mathrm{nM})$ & 5 & $621,33( \pm 54,24)$ \\
RNAiMAX $(2 \mathrm{uL})+$ siGLO $(75 \mathrm{nM})$ & 5 & $934,65( \pm 119,43)$ \\
RNAiMAX $(2 \mathrm{uL})+$ siGLO $(100 \mathrm{nM})$ & 5 & $544,89( \pm 16,65)$ \\
Controle $(\mathrm{DMEM})$ & 5 & $0,0( \pm 54,24)$ \\
\hline
\end{tabular}

Os valores médios de pixels normalizados, obtidos de cada tratamento com Lipofectamine RNAiMAX, foram analisados estatisticamente. Como demonstrado no gráfico abaixo (Figura 15), todos os tratamentos apresentaram diferença estatística quando comparados com o grupo controle de CG (DMEM), no entanto não diferirem significativamente entre si. 


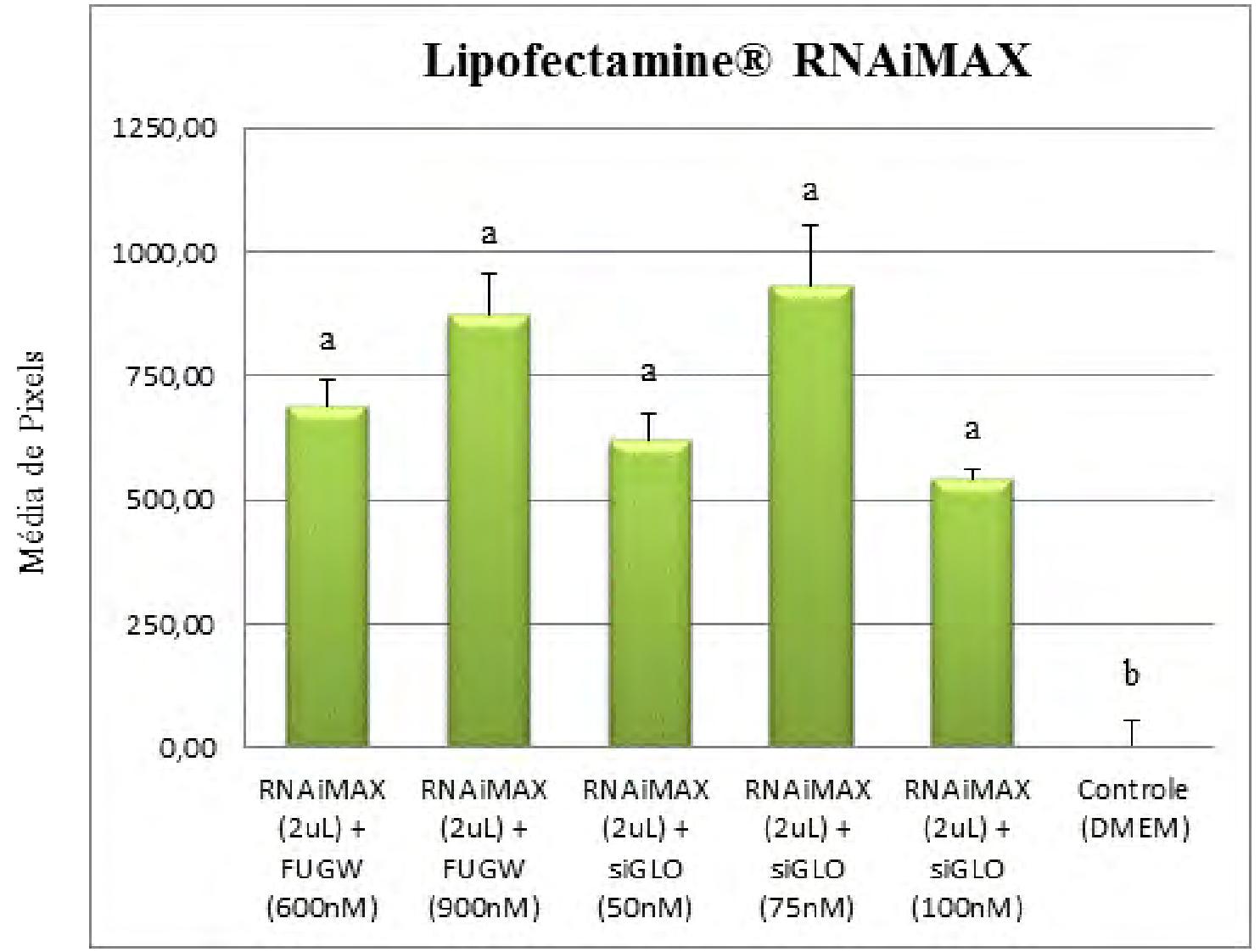

Figura 15. Valores médios de pixels medidos pelo programa computacional ImageJ ${ }^{\circledR}$ para os grupos de CG submetidas à exposição de $2 \mu \mathrm{L}$ Lipofectamine ${ }^{\circledR}$ RNAiMAX + 600 e $900 \mathrm{nM}$ do plasmídeo transgênico FUGW ou 50, 75 e 100 nM do marcador comercial siGLO. Os dados são apresentados como média $( \pm \mathrm{EPM})$ e as letras diferentes representam diferença significativa $(\mathrm{p}<0,05)$.

\subsubsection{Lipofectamine ${ }^{T M} 2000$}

Os grupos de CG submetidos à exposição de Lipofectamine ${ }^{\mathrm{TM}} 2000$ + Plasmídeo FUGW, para todas as concentrações, também apresentaram visualmente uma baixa porcentagem de células transfectadas (30-40\%), no entanto, com boa intensidade de fluorescência (Figura 16). Já, os grupos de CG expostos à Lipofectamine ${ }^{\mathrm{TM}} 2000+$ siGLO $^{\circledR}$, para todas as concentrações, apresentaram visualmente uma elevada eficiência de lipofecção, demonstrada tanto por uma alta intensidade quanto porcentagem de células emitindo fluorescência (70-80\%) (Figuras 17 e 18). Em relação à quantidade de pixels 
captados das fotomicrografias, todos os grupos expostos ao agente Lipofectamine ${ }^{\mathrm{TM}} 2000$ diferiram estatisticamente dos grupos controles de CG $(\mathrm{p}<0,05)$ (Tabela 2 e Figura 19).

Entretanto, os grupos experimentais submetidos à exposição de $1 \mu 1$ de Lipofectamine $^{\mathrm{TM}} 2000$ também não apresentaram fluorescência alguma, enquanto os submetidos a $3 \mu \mathrm{l}$ apresentaram uma elevada taxa de degradação celular. Quanto aos indicadores de transfecção, tanto o plasmídeo transgênico FUGW, confeccionado em laboratório, quanto o marcador sintético $\mathrm{siGLO}^{\circledR}$, em todas as concentrações $(300,600 \mathrm{e}$ 900nM e 30, 50, 75 e $100 \mathrm{nM}$, respectivamente), quando adicionados aos grupos de CG expostos a $2 \mu 1$ de Lipofectamine ${ }^{\mathrm{TM}} 2000$, proporcionaram algum padrão de fluorescência, sendo este mediano para o marcador FUGW e bastante elevado para o siGLO ${ }^{\circledR}$, indicando maior eficiência de lipofecção para o agente de lipofecção Lipofectamine $^{\mathrm{TM}}$ 2000. Portanto, todos os grupos de CG expostos a este agente, tanto acrescido do marcador FUGW, quanto do $\mathrm{siGLO}^{\circledR}$, foram incluídos na análise estatística. 

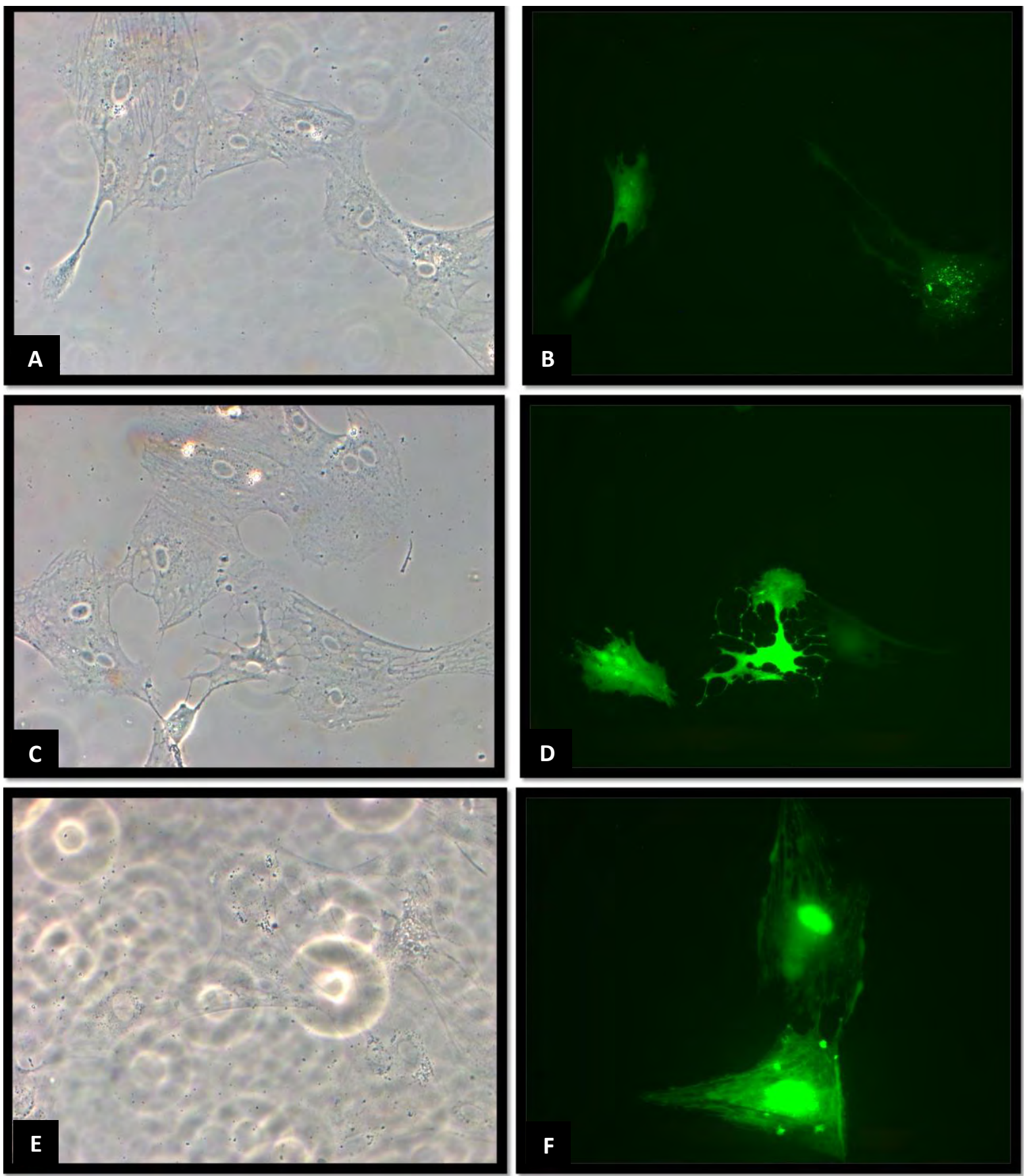

Figura 16. Fotomicrografias $(400 \mathrm{X})$ de luz normal (A, C e E) e de fluorescência (B, D e F $400 \mathrm{~ms}$ ) de CG submetidas à lipofecção com o agente lipofector Lipofectamina ${ }^{\mathrm{TM}} 2000$ e o marcador plasmídeo FUGW. Estão representadas apenas as concentrações que proporcionaram fluorescência celular: $2 \mu \mathrm{L}$ de Lipofectamine ${ }^{\mathrm{TM}} 2000+300 \mathrm{nM}$ do FUGW (A e B); $2 \mu \mathrm{L}$ de Lipofectamine $^{\mathrm{TM}}+60$ 0nM do FUGW (C e D); $2 \mu \mathrm{L}$ de Lipofectamine $^{\mathrm{TM}} 2000+900 \mathrm{nM}$ do FUGW (E e F). 

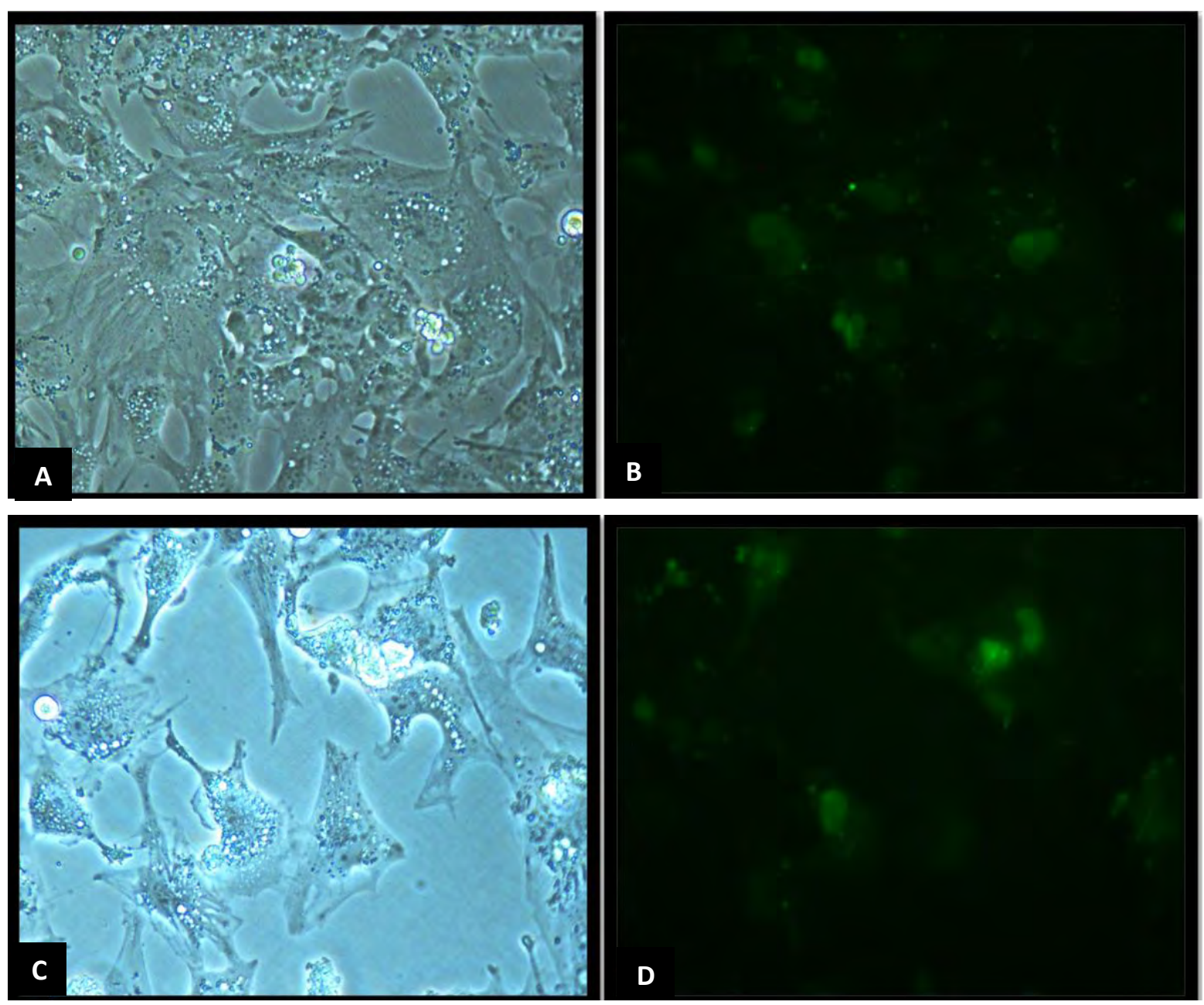

Figura 17. Fotomicrografias (400X) de luz normal (A e C) e de fluorescência (B e D - 400ms) de CG submetidas à lipofecção com o agente lipofector Lipofectamina ${ }^{\mathrm{TM}} 2000$ e o marcador siGLO®. Estão representadas as seguintes concentrações: $2 \mu \mathrm{L}$ de Lipofectamine ${ }^{\mathrm{TM}} 2000+30$ $\mathrm{nM}$ de siGLO® (A e B); $2 \mu \mathrm{L}$ de Lipofectamine ${ }^{\mathrm{TM}} 2000+50 \mathrm{nM}$ de siGLO® $(\mathrm{C}$ e D). 

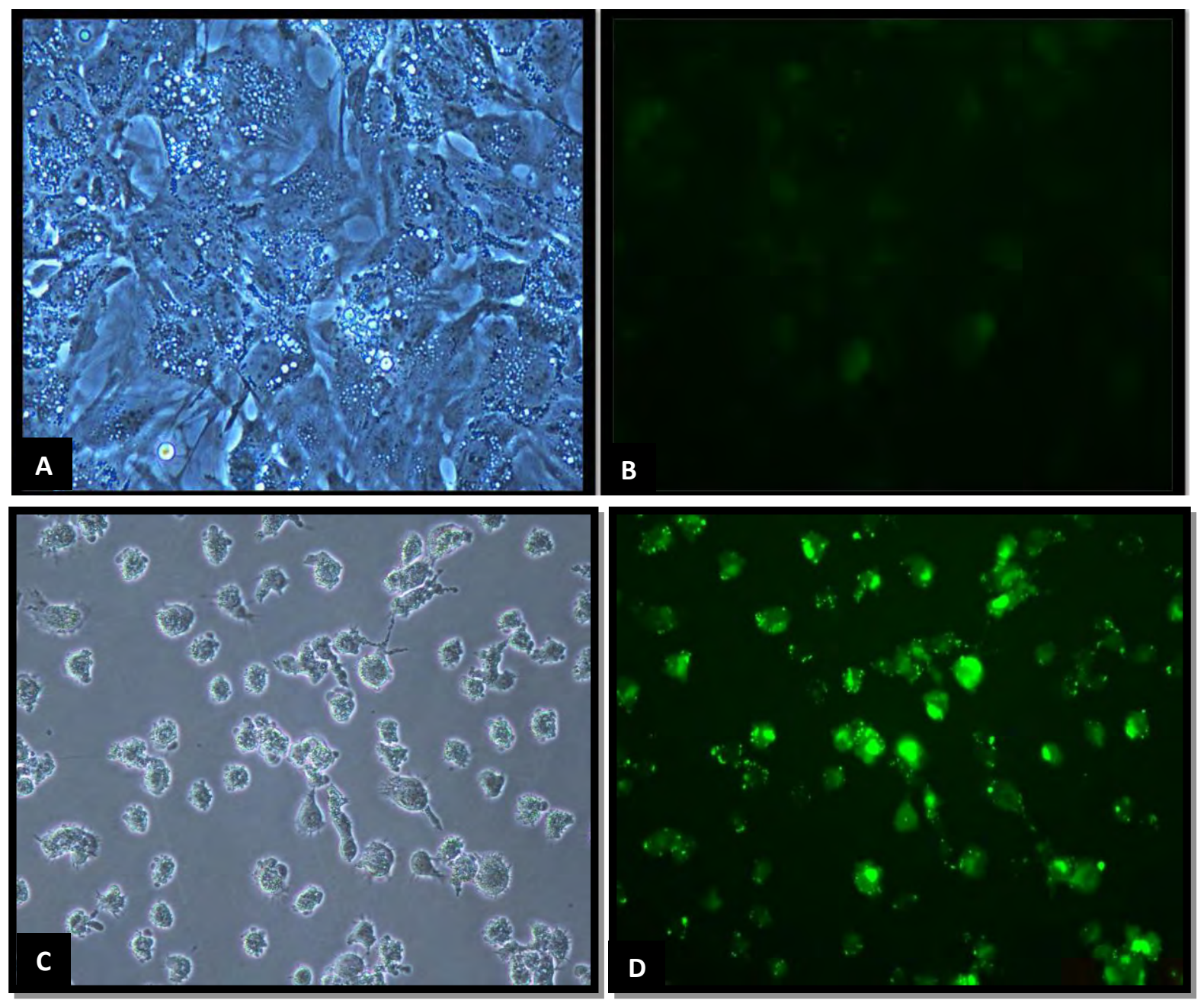

Figura 18. Fotomicrografias (400X) de luz normal (A e C) e de fluorescência (B e D - 400ms) de CG submetidas à lipofecção com o agente lipofector Lipofectamina ${ }^{\mathrm{TM}} 2000 \mathrm{e}$ o marcador siGLO®. Estão representadas as seguintes concentrações: $2 \mu \mathrm{L}$ de Lipofectamine ${ }^{\mathrm{TM}} 2000+75$ nM de siGLO® (A e B); $2 \mu \mathrm{L}$ de Lipofectamine ${ }^{\mathrm{TM}} 2000+100 \mathrm{nM}$ de siGLO® (C e D). 
Tabela 2. Médias de pixels captados a partir das fotomicrografias, referentes aos diferentes grupos experimentais de CG expostos à $2 \mu 1$ do reagente Lipofectamine ${ }^{\mathrm{TM}} 2000$ com seus respectivos desvios padrões.

\section{Médias}

Grupos Número de Repetições

(Pixels)

\begin{tabular}{|c|c|c|}
\hline Lipof. $2000(2 \mathrm{uL})+$ FUGW (300nM) & 5 & $6397,00( \pm 758,81)$ \\
\hline Lipof. $2000(2 \mathrm{uL})+$ FUGW (600nM) & 5 & $67013( \pm 1040,83)$ \\
\hline Lipof. $2000(2 \mathrm{uL})+$ FUGW (900nM) & 5 & $7947( \pm 360,56)$ \\
\hline Lipof. $2000(2 \mathrm{uL})+$ siGLO $(30 \mathrm{nM})$ & 5 & $4222,33( \pm 284,14)$ \\
\hline Lipof. $2000(2 \mathrm{uL})+$ siGLO $(50 \mathrm{nM})$ & 5 & $4484,00( \pm 366,58)$ \\
\hline Lipof. $2000(2 \mathrm{uL})+$ siGLO $(75 \mathrm{nM})$ & 5 & $5775,67( \pm 686,20)$ \\
\hline Lipof. $2000(2 \mathrm{uL})+$ siGLO (100nM) & 5 & $12119,00( \pm 519,95)$ \\
\hline Controle (DMEM) & 5 & $0,0( \pm 119,8)$ \\
\hline
\end{tabular}

Os valores médios de pixels normalizados, obtidos de cada tratamento com Lipofectamine $^{\mathrm{TM}} 2000$, foram analisados estatisticamente. Nesta análise, foi possível constatar que todos os tratamentos apresentaram diferença estatística quando comparados com o grupo controle de CG (DMEM), além de diferirem entre si, como demostrado no gráfico abaixo (Figura 19). 


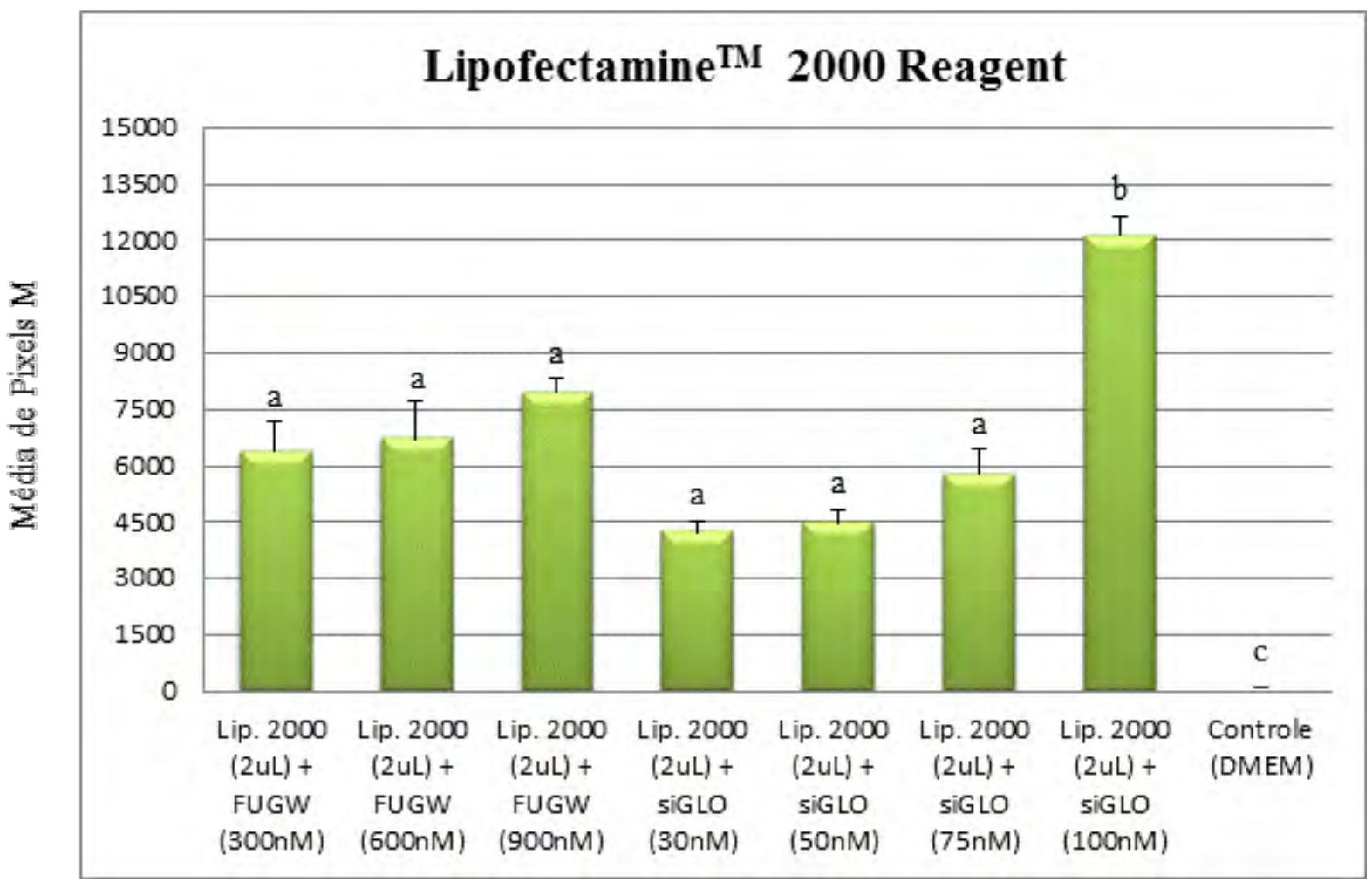

Figura 19. Valores médios de pixels medidos pelo programa computacional ImageJ ${ }^{\circ}$ para os grupos de CG submetidas à exposição de $2 \mu \mathrm{L}$ Lipofectamine $^{\mathrm{TM}} 2000+300,600$ e $900 \mathrm{nM}$ do plasmídeo transgênico FUGW ou 30, 50, 75 e $100 \mathrm{nM}$ do marcador comercial siGLO, assim como grupo controle de CG não exposto às drogas e em meio de cultivo convencional (DMEM com aditivos). Os dados são apresentados como média ( \pm EPM) e as letras diferentes representam diferença significativa $(\mathrm{p}<0,05)$.

\subsection{Discussão}

As células da granulosa são um dos constituintes do ambiente folicular de grande importância para a aquisição da competência oocitária, ovulação e fertilização em mamíferos, portanto, a complexa interação que ocorre entro o oócito e essas células somáticas, assim como sua exata influência na qualidade oocitária e embrionária, tem sido alvo de inúmeros estudos, mas muitas questões ainda necessitam ser esclarecidas, principalmente na espécie bovina (RICHARD e SIRARD, 1996). Assim, um melhor entendimento sobre essa interação, principalmente em relação aos possíveis genes e proteínas envolvidos no processo de capacitação oocitária, torna-se crucial para a adequada regulação da maturação oocitária in vitro, a fim de possibilitar a total 
competência do oócito em suportar a embriogênese (CAIXETA et al. 2009; TESFAYE et al. 2009).

Inúmeras metodologias de transfecção já foram descritas para a introdução de RNAs de interferência em células de mamíferos, com o intuito de se obter sucesso na técnica de silenciamento gênico e, consequentemente, de se conhecer mais afundo o papel de alguns genes de interesse. No entanto, as baixas eficiências de transfecção observadas, proporcionada por motivos variados, como alta toxicidade e elevado índice de degradação celular, torna-se uma limitação para a realização dessa técnica. Por isso, a metodologia de transfecção mediada por lipossomas catiônicos (lipofecção), parece ser a mais adequada e eficiente para silenciar genes específicos em células (OLIVEIRA et al., 2005), visto que possuem menor toxicidade, reduzido índice de danos celulares e maior facilidade de manipulação quando comparados com as metodologias que utilizam vetores virais ou mecânicos, como a microinjeção (MEVEL et al., 2010).

Os lipossomas encapsulam o ácido nucléico a ser transfectado devido à diferença de cargas elétricas, formando os complexos lipossomas-ácido nucléico, os quais se fundem à membrana plasmática e são internalizados por endocitose (KURRECK, 2003), liberando seu conteúdo no interior da célula que, posteriormente será endereçado ao núcleo (DASS, 2004).

Para o estabelecimento do cultivo celular de células da granulosa bovinas, utilizou-se o protocolo de Kobayashi et al. (2007). O início dos procedimentos de lipofecção foi baseado em trabalhos de Oliveira e colaboradores (2005), que comprovaram a eficiência da técnica de trasfecção mediada por lipossomas realizada em células fibroblásticas.

No presente trabalho, a eficácia das lipofecções foi averiguada, inicialmente, por uma análise visual da integridade do cultivo e proporção de células degeneradas nos diferentes grupos experimentais, às 24 e 48 horas de cultivo in vitro. Às 48 horas de exposição das CG aos diferentes reagentes de lipofecção, foi possível detectar um elevado grau de degradação celular, incluindo danos diversos e morte celular, o que comprova a existência de certa citotoxicidade dos agentes lipofectores utilizados. A relativa toxicidade de lipossomas catiônicos varia de acordo com o tipo celular e com a quantidade de lipossomas utilizada (PATIL et al., 2005; ROMOREN et al., 2005). Já às 24 horas de cultivo in vitro, as células apresentavam-se bastante íntegras e com poucas modificações morfológicas, mostrando-se, portanto, como o melhor tempo de exposição 
das células às drogas de lipofecção. Diante disso, foi possível padronizar um período de 24 horas como melhor tempo de lipofecção, visto que este período de exposição não proporcionou danos ou modificações celulares determinantes.

Quanto aos agentes lipofectores Lipofectamine ${ }^{\circledR}$ RNAiMAX e Lipofectamine ${ }^{\mathrm{TM}}$ 2000, ambos apresentaram ineficiência de lipofecção quando adicionados aos grupos de CG na quantidade de $1 \mu \mathrm{L}$ por tratamento (poço), visto que, visualmente, não proporcionaram nenhuma fluorescência celular, indicativo de que essa quantidade de lipossomas não foi suficiente para encapsular e transportar os marcadores siGLO® ou FUGW para o interior das células. Já os grupos experimentais submetidos a $3 \mu 1$ dos agentes lipofectores, apresentaram uma elevada proporção de células degradadas, indicando que quantidades superiores a $2 \mu$ l desses lipossomas comerciais tornam-se altamente tóxicas para cultivos primários de células da granulosa bovinas.

Os grupos de CG submetidos à exposição de $2 \mu 1$ dos lipossomas comerciais Lipofectamine ${ }^{\circledR}$ RNAiMAX e Lipofectamine ${ }^{\mathrm{TM}} 2000$, foram inicialmente submetidos à uma análise visual de fluorescência, a qual indicou uma eficiência de lipofecção consideravelmente maior nos grupos de CG submetidos à exposição com Lipofectamine $^{\mathrm{TM}}$ 2000. Os grupos de CG submetidos à exposição da Lipofectamine ${ }^{\circledR}$ RNAiMAX, tanto na presença do marcador siGLO® quanto do plasmídeo transgênico FUGW, confeccionado em laboratório, para todas suas concentrações, apresentaram baixa ou nenhuma fluorescência.

Os grupos experimentais de CG submetidos à exposição de Lipofectamine ${ }^{\mathrm{TM}}$ 2000, tanto na presença do marcador transgênico FUGW, quanto do indicador comercial siGLO ${ }^{\circledR}$, para todas as concentrações, apresentaram algum padrão de fluorescência celular, sendo este mediano para o plasmídeo FUGW e bastante elevado para o siGLO ${ }^{\circledR}$, demonstrada tanto por uma alta intensidade quanto porcentagem de células emitindo fluorescência (70-80\%). Portanto, a adição do agente lipfector comercial Lipofectamine $^{\mathrm{TM}} 2000$ propiciou elevada eficiência de lipofecção. Ainda nos grupos submetidos à exposição de $100 \mathrm{nM}$ do indicador de transfecção siGLO ${ }^{\circledR}$, foi observado uma maior eficiência de lipofecção em comparação aos demais tratamentos.

A eficiência alcançada para a técnica de lipofecção no presente trabalho (80 a 90\%), foi muito superior à obtida em trabalhos anteriores, como o de Paulini (2010) e Gao et al. (2009), que alcançaram, respectivamente, uma eficiência máxima de $20 \%$ e $61 \%$ para a mesma técnica. Já Wang et al. (2011) descreveram uma eficiência de 89\% 
para a técnica em CG suínas, no entanto com a utilização do agente Lipofectamine RNAiMAX e não Lipofectamine 2000. Assim, os resultados sugerem a obtenção de uma excelente metodologia para a execução da técnica de transfecção mediada por lipossomas em CG bovinas. Além disso, mostram a importância de se estabelecer as condições adequadas de lipofecção para cada tipo celular e condição de cultivo, antes de iniciar trabalhos com silenciamento gênico usando esse sistema de introdução do siRNA.

A partir dos ensaios experimentais realizados no presente trabalho e diante da elevada eficiência alcançada para a técnica de lipofecção, foi possível padronizar as melhores condições da técnica em células da granulosa bovinas, averiguadas às $24 \mathrm{~h}$ de cultivo in vitro com a utilização de $2 \mu l$ do agente lipofector comercial Lipofectamine ${ }^{\mathrm{TM}}$ 2000 acrescido de $100 \mathrm{nM}$ do marcador siGLO $^{\circledR}$. A partir de tal padronização, torna-se possível o estabelecimento de uma metodologia de silenciamento gênico por lipofecção em CG. Tal estratégia poderá ser utilizada como uma potente ferramenta para o estudo funcional de genes e proteínas de interesse expressos nessas células somáticas e, principalmente, que possam estar relacionados ao adequado funcionamento do oócito. Esse sistema poderá contribuir para a elucidação dos processos morfofisiológicos envolvidos na interação entre o oócito e as células da granulosa na espécie bovina. A melhor compreensão acerca dessa comunicação é de fundamental importância para o aprimoramento do cultivo de oócitos in vitro e, consequentemente, para o incremento das taxas de eficiência em técnicas reprodutivas como a fertilização e a produção de embriões in vitro (PIV e FIV). 
CAPÍTULO V

\section{Experimento 2}




\section{SILENCIAMENTO GÊNICO DO BMPRII EM CÉLULAS DA GRANULOSA BOVINAS}

"Gene silencing of BMPRII in bovine granulosa cells" 


\section{RESUMO}

As células da granulosa (CG) são constituintes do ambiente folicular imprtantes para o desenvolvimento, maturação e aquisição da competência oocitária, desempenhando funções como a esteroidogênese, expressão de receptores de LH (LHR) e síntese de vários transcritos e proteínas essenciais. Contudo, a funcionalidade e ação destas células são dependentes de alguns fatores derivados do oócito, como o GDF9 e o BMP15. A ação desses fatores, por sua vez, depende da sinalização via receptor BMPRII, já identificado em células da granulosa de mamíferos, porém com suas funções ainda pouco conhecidas na espécie bovina. O silenciamento gênico por lipofecção consiste num método de transfecção de fácil manipulação, bastante eficiente e pouco agressivo para as células, representando uma importante ferramenta para o estudo funcional de genes e proteínas celulares. Diante da importância do BMPRII para a funcionalidade das células da granulosa e, consequentemente, dos oócitos inclusos no ambiente folicular, o objetivo do presente trabalho foi desenvolver uma metodologia de silenciamento gênico por lipofecção do BMPRII em CG bovinas, utilizando a técnica de RNA de interferência, a fim de possibilitar uma redução considerável de sua expressão, tanto em termos de RNAm quanto de proteína. Para tanto, a partir das condições ótimas de lipofecção em CG bovinas, estabelecidas em estudos prévios, realizou-se o silenciamento gênico do BMPRII testando diferentes concentrações do siRNA (0 a 500pM) específico para este gene (siBMPRII). Após 24 horas de cultivo in vitro com as diferentes quantidades do siBMPRII, as CG de cada grupo experimental foram avaliadas quanto à abundância relativa de mRNA BMPRII por PCR em tempo real. Todas as concentrações resultaram em uma redução semelhante de transcritos, não diferindo significativamente entre si. Para o experimento seguinte adotou-se então a menor concentração (100 pM), para determinação do tempo mínimo de cultivo requerido para se obter a máxima eficiência no processo de silenciamento gênico do BMPRII. Os grupos de CG foram tratados por 0, 6 , 12,18 e 24 h e, posteriormente, avaliados quanto à abundância relativa de transcritos de BMPRII. Como controle, foram utilizados sempre grupos de CG não expostos às drogas. Os tempos de incubação que proporcionaram uma redução mais expressiva do mRNA para o BMPRII foram 12 e 24 horas. A melhor concentação de siBMPRII (100nM) e melhor tempo de incubação foram ainda avaliados pela técnica de western blotting, 
confirmando a redução da expressão do BMPRII também em nível de proteína. Em conclusão, este trabalho possibilitou o desenvolvimento de uma metodologia de silenciamento gênico por lipofecção do BMPRII em CG bovinas, a qual poderá ser utilizada como importante ferramenta para o estudo funcional deste gene e de outros de interesse.

Palavras-chave: siRNA; lipofecção; GDF9; BMP15; Knockdown;

\begin{abstract}
Granulosa cells (GC) are important constituents of the follicular environment which are important for the development, maturation and acquisition of oocyte competence, performing functions such as steroidogenesis, expression of LH receptor (LHR) and synthesis of many essential transcripts and proteins. However, the functionality and action of these cells are dependent on some factors derived from the oocyte, such as GDF9 and BMP15. The action of these factors, in turn, depends on signaling via BMPRII receptor, which has been identified in granulosa cells of mammals, but its functions are still not well defined in bovine species. Gene silencing by transfection using the lipofection method is easy to handle, efficient and less aggressive to the cells, representing an important tool for the functional study of genes and cellular proteins. Given the importance of BMPRII to the functionality of granulosa cells and oocytes, the aim of this work was to develop a method of gene silencing by lipofection of BMPRII in bovine GC, using the technique of RNA interference in order to allow a considerable reduction of its expression, in terms of mRNA and protein. From the optimal conditions for lipofection in bovine CG, established in previous studies, the knockdown of BMPRII was tested using different concentrations of siRNA (0 to $500 \mathrm{pM}$ ) specific for this gene (siBMPRI ). After 24 hours of culture in vitro with different concentrations of siBMPRII, the $\mathrm{CG}$ of each experimental group were evaluated for relative abundance of BMPRII mRNA by real-time PCR. All concentrations resulted in a similar reduction of transcripts and did not differ significantly from each other. For the next experimentthe lowest concentration $(100 \mathrm{pM})$ was adoptedto determine the minimum cultivation time required to obtain the maximum efficiency in the gene silencing of BMPRII. Groups of GC were treated for $0,6,12,18$ and 24 hours and thereafter evaluated for the relative abundance of
\end{abstract}


BMPRII transcripts . As a control, CG were not exposed to drugs. Incubation times that provided greater reduction in mRNA for BMPRII were 12 and 24 hours. The best concentration of siBMPRII $(100 \mathrm{nM})$ and incubation time were also evaluated by western blotting, confirming the reduction of BMPRII expression also at protein level. In conclusion, this work has enabled the development of a methodology for gene silencing by lipofection of the BMPRII in bovine CG, which can be used as an important tool for the functional analysis of this gene and others of interest.

Keywords: siRNA; lipofection; GDF9; BMP15; Knockdown. 


\subsection{Introdução}

O folículo ovariano consiste na unidade morfofuncional do ovário, onde o oócito e as células somáticas que o circundam (células tecais e granulosa) são intimamente associados e interdependentes (MOENTER et al., 1992). Dentro de cada folículo, um oocito é circundado de uma ou várias camadas de células da granulosa, dependendo de seu estágio de desenvolvimento.

Durante a oogênese, que ocorre no interior da estrutura folicular, o oócito adquire a maquinaria molecular e citoplasmática necessária para suportar o desenvolvimento embrionário, em um processo denominado capacitação oocitária (GILCHRIST et al., 2008). No entanto, durante o processo de maturação, o oócito não é auto-suficiente para concluir o seu desenvolvimento e capacitação, visto que tais processos exigem uma comunicação bi-direcional constante entre o oócito e as células somáticas que o circundam, tais como as da teca e as da granulosa (GANDOLFI et al. 2005), o que torna esta interação essencial para a aquisição da competência oocitária, fertilização e geração de um embrião com alto potencial de desenvolvimento na produção in vitro (TANGHE $e t$ al., 2002; FAIR, 2003; GANDOLFI et al. 2005; GILCHRIST et al., 2008).

As células da granulosa são, sabidamente, um dos constituintes do ambiente folicular de grande importância para a aquisição da competência oocitária, ovulação e fertilização em mamíferos, visto que desempenham funções como a esteroidogênese, expressão de receptores de LH (LHR), secreção de inibina A e B (INHA e INHB), síntese de inúmeros transcritos e proteínas essenciais, além da produção e secreção de fatores químicos necessários para manter o oócito em bloqueio meiótico (RICHARD e SIRARD, 1996). No entanto, a interação oócito-células da granulosa in vitro e in vivo, assim como sua influência na qualidade oocitária e embrionária, ainda necessita ser melhor esclarecida, em especial na espécie bovina. Por isso, torna-se importante o melhor entendimento acerca de possíveis genes e proteínas envolvidos no processo de capacitação oocitária, para a adequada regulação da maturação in vitro (CAIXETA et al. 2009; TESFAYE et al. 2009).

A funcionalidade e ação das células da granulosa são, entretanto, dependentes de alguns fatores derivados do oócito, capazes de atuar diretamente nos processos coordenados de maturação folicular através de uma sinalização parácrina (LI et al. 2008b; HUTT e ALBERTINI, 2007). Dentre os diversos fatores produzidos pelo oócito e 
propagados às células da granulosa, se destacam os membros da superfamília TGF $\beta$ e, dentre estes, o GDF9 (growth and differentiation factor 9) e o BMP15 (bone morphogenetic protein 15), que são expressos ao longo do desenvolvimento folicular na espécie bovina e estão envolvidos no controle da proliferação, diferenciação e função das células da granulosa, além de melhorarem consideravelmente a competência de desenvolvimento do oócito (EPPIG, 2001; MATZUK et al., 2002; GILCHRIST et al., 2004; HUSSEIN et al., 2005; HUTT e ALBERTINI, 2007). O GDF9 e o BMP15 ainda estão intimamente implicados em todos os estágios da foliculogênese (GILCHRIST et al., 2008), na esteroidogênese e na inibição da luteinização das células somáticas que cincundam o oócito (GILCHRIST et al., 2006), além de estarem envolvidos no processo de maturação e nos eventos que antecedem a ovulação como, por exemplo, a expansão das células do cumulus oophurus (DONG et al. 1996; HANRAHAN et al., 2004; YOSHINO et al.. 2006; LI et al., 2008a;b). Esses fatores parácrinos parecem ser, portanto, a chave reguladora para manter a complexa arquitetura ovariana e a fertilidade das fêmeas, a partir de ações regulatótórias sobre o oócito e as células da granulosa (VITT e HSUEH, 2001; WU e- MATZUK, 2002; MCNATTY et al., 2004; GILCHRIST et al., 2004).

No entanto, a ação desses fatores parácrinos depende da sinalização via receptor da proteína morfogenética óssea tipo II (BMPRII), receptor este já identificado em células da granulosa de todas as categorias foliculares de mamíferos (WILSON et al., 2001; SOUZA et al., 2002; SILVA et al., 2006; LIMA et al., 2012) e que possui vital importância para a funcionalidade destas células e do oócito (MAZERBOURG e HSUEH, 2006).

Células da granulosa cultivadas in vitro, mesmo durante o processo de luteinização, continuam expressando os receptores BMPRII. Portanto, essas células possuem total capacidade de serem estudadas quanto à expressão deste receptor específico ao longo de todo o cultivo in vitro (RUA et al., 2009), a fim de elucidar os complexos mecanismos de atuação do BMP15 e do GDF9.

A técnica de RNA de interferência (RNAi), utilizada para o processo de silenciamento gênico, consiste numa importante ferramenta para investigar a função de genes e proteínas celulares (BARBOSA e LIN, 2004). Dentre os diversos métodos desenvolvidos com o intuito de transportar o RNAi para o interior da célula, a lipofecção pode ser considerada uma das técnicas mais adequadas e eficientes para proporcionar o 
silenciamento gênico, visto que apresenta fácil manipulação, alta eficiência na transfecção, baixa toxicidade e reduzido índice de danos celulares e, além disso, não demanda elevado investimento e pessoal técnico altamente especializado, podendo ser considerado o método mais recomendado para proporcionar o silenciamento de um gene em células in vitro e in vivo (OLIVEIRA et al., 2005). Tal técnica utiliza lipossomas para a transfecção, os quais encapsulam o ácido nucléico a ser transfectado devido à diferença de cargas elétricas e, neste sistema, o complexo lipídio-ácido nucléico é então internalizado por endocitose (KURRECK, 2003), liberando o siRNA no interior das células da granulosa célula, o qual será conduzido até o núcleo da mesma. Dentre os diversos tipos de lipossomas comercias disponíveis atualmente, a Lipofectamine ${ }^{\mathrm{TM}} 2000$ se mostrou bastante eficiente no processo de transfecção realizado em células da granulosa bovinas, superando consideravelmente a eficiência apresentada por outro tipo de lipossoma comercial, o Lipofectamine RNAiMAX (CASTRO et al., dados ainda não publicados).

Diante da importância do BMPRII, diretamente envolvido na comunicação entre oócitos e células da granulosa, para a funcionalidade das células da granulosa e, consequentemente, dos oócitos que se desenvolvem no ambiente folicular, e visto que o papel deste receptor em células da granulosa bovinas ainda é pouco conhecido, o objetivo do presente trabalho foi desenvolver uma metodologia com as condições ideais para promover o silenciamento gênico do BMPRII em células da granulosa nesta espécie. Para tanto, utilizou-se a técnica de RNA de interferência mediada por lipofecção, adotando-se as melhores condições (tempo de exposição e concentração), previamente padronizadas para tal técnica, a fim de possibilitar a futura utilização de tal estratégia como ferramenta para o estudo funcional e investigação mais acurada do papel do BMPRII e outros genes de interesse expressos nas células da granulosa bovinas e ainda pouco conhecidos. Tal metodologia poderá ser eficientemente empregada para a obtenção de maiores informações a respeito da comunicação existente entre as células da granulosa e os oócitos bovinos, permitindo, dessa forma, o desenvolvimento de condições de cultivo in vitro mais adequadas que promovam melhores resultados na fertilização e produção in vitro de embriões, com conseqüente aplicação prática.

\subsection{Material e Métodos}




\subsubsection{Obtenção das células da granulosa}

Ovários de fêmeas bovinas foram coletados de abatedouro comercial, logo após o abate e transportados ao Laboratório de Histologia Animal da Faculdade de Zootecnia e Engenharia de Alimentos da Universidade de São Paulo - USP, Campus de Pirassununga/SP, em solução salina $(0,9 \%$ de $\mathrm{NaCl})$ acrescida dos antibióticos penincilina/esteptomicina (10 UI/mL e $10 \mu \mathrm{g} / \mathrm{mL}$, respectivamente; Gibco®), à temperatura de $30^{\circ} \mathrm{C}$. Os ovários foram lavados em solução salina (igual à do transporte) e, posteriormente, em álcool 70\%. Para obtenção das células da granulosa, os folículos de 2 a $6 \mathrm{~mm}$ foram aspirados com auxílio de uma agulha $18 \mathrm{G}$ acoplada a uma seringa de 10 mL. O líquido folicular obtido foi dispensado em uma placa de Petri de $100 \mathrm{~mm}$ para a remoção dos complexos cumulus-oócitos (CCO) dispersos no meio com o auxílio de uma lupa estereoscópica. O líquido folicular contendo apenas as células da granulosa (CG) foi transferido para tubos de $15 \mathrm{~mL}$ (TPP) e lavado duas vezes por centrifugação (20 min a 980 x $\mathrm{g}$ ) em meio de cultivo celular DMEM (Gibco®) completo contendo $44 \mathrm{mM}$ de $\mathrm{NaHCO}_{3}$, FSH $(1 \mu \mathrm{g} / \mathrm{mL})$, ciprofloxacina $\left(50 \mu \mathrm{g} / \mathrm{mL}\right.$; Sigma-Aldrich $\left.{ }^{\circledR}\right)$, anfotericina B $\left(2,5 \mu \mathrm{g} / \mathrm{mL}\right.$; Sigma-Aldrich $\left.{ }^{\circledR}\right)$ e $5 \%$ de soro fetal bovino (SFB; Gibco®).

\subsubsection{Cultivo das células da granulosa}

Após a última lavagem em meio DMEM completo, o pellet de células formado foi resuspendido em $1 \mathrm{~mL}$ do mesmo meio e transferido para placa de Petri (100mm), onde as células foram cultivadas em estufa a $38,5^{\circ} \mathrm{C}$ em $5 \%$ de $\mathrm{CO}_{2} \mathrm{em}$ ar. As placas de cultivo celular foram submetidas a trocas diárias de meio, a fim de se remover completamente eventuais células mortas ou restos celulares presentes. Ao atingir confluência, cerca de 48 horas após o início do cultivo in vitro, o meio de cultivo foi descartado e as células lavadas duas vezes com PBS livre de cálcio e magnésio e separadas com $5 \mathrm{~mL}$ de uma solução $0,05 \%$ de tripsina e 0,02\% EDTA (Gibcoß) em PBS. Após a separação, as células da granulosa foram lavadas duas vezes por centrifugação $(20 \min 980$ x $g$ ) em DMEM completo. Posteriormente à última lavagem, as células contadas em câmara de Neubauer e tiveram sua viabilidade estimada através do corante Azul de Tripan 0,4\% (Gibco®). Em seguida, as CG foram semeadas a 5 x $10^{4}$ células/poço em placas Nunc de 
4 poços e cultivadas in vitro, a $38,5^{\circ} \mathrm{C}$ e $5 \%$ de $\mathrm{CO}_{2}$ em ar, por um período de 48 horas ou até que os grupos de células da granulosa apresentassem confluência adequada para os tratamentos de lipofecção (80-90 \%).

\subsubsection{Avaliação do comportamento temporal das células da} granulosa ao longo de um período de 24 horas

Anteriormente aos experimentos de silenciamento por lipofecção, procedeu-se a realização de um ensaio de expressão temporal do gene BMPRII nas células da granulosa bovinas, a fim de padronizar a técnica de PCR em tempo real e conhecer o comportamento desse gene nessas células somáticas ao longo de um período de 24 horas, período este, selecionado para iniciar os ensaios de silenciamento gênico por lipofecção. Para tal, as CG foram inicialmente cultivadas em placas de 4 poços e, após um período de 48 horas, os meios de cultivo convencionais (DMEM completo) foram descartados e substituídos por meios novos e iguais, a fim de se simular exatamente as condições temporais da lipofecção. As células da granulosa foram então submetidas ao cultivo em meio DMEM convencional, não expostos às drogas de lipofecção, por períodos de 6, 12 , 18 e 24 horas e, após cada um desses períodos, as células foram submetidas a análises por PCR em tempo real quanto à expressão gênica do BMPRII.

\subsubsection{Silenciamento gênico in vitro por lipofecção do siRNA}

Após 48 horas de cultivo in vitro, quando a confluência já estava adequada para receber os tratamentos de lipofecção (80 a 90\%), o meio de cultivo (DMEM completo) foi descartado e as células lavadas com DMEM (Gibco®) sem aditivos para a total remoção de traços de antibiótico, fungicida e SFB, visto que estes aditivos diminuem a eficiência da lipofecção. Após a lavagem, os grupos de CG foram submetidos às condições ótimas de lipofecção acrescidas do siRNA específico para o BMPRII (siBMRII).O desenho do siRNA para o gene BMPRII foi realizado através da plataforma Débora, elaborada pelo Laboratório de Genética Molecular, UNICAMP-Campinas/SP (Tabela 3). 
Tabela 3. Sequências nucleotídicas do siRNA para o gene BMPRII.

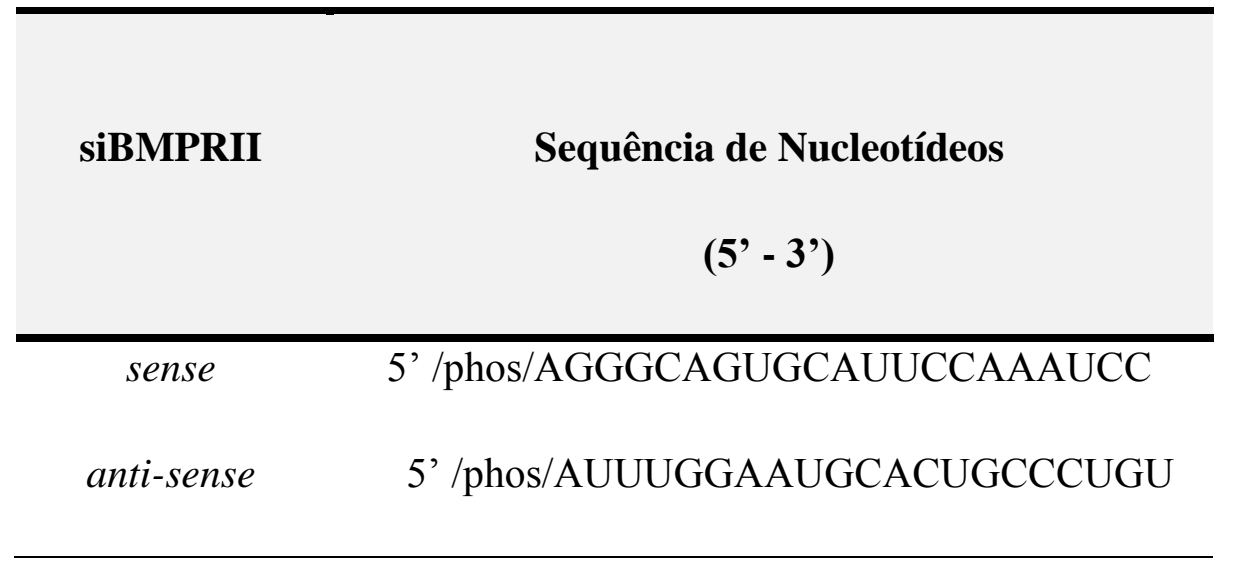

Em tubos de 0,2 mL foram preparadas as soluções $A$ e $B$ de lipofecção designadas a cada poço (tratamento). A solução $A$ continha o marcador de transfecção siGLO ${ }^{\circledR}(100$ $\mathrm{nM}$; Thermo Scientific Dharmacon ${ }^{\circledR}$ ), responsável por determinar a eficiência da técnica de lipofecção através da emissão de um sinal verde quando observado por microscopia de fluorescência, diluído em $50 \mu \mathrm{L}$ de meio Opti-MEM® (Gibco®); e a solução $B$ continha o agente lipofector Lipofectamine ${ }^{\mathrm{TM}} 2000$ ( $2 \mu \mathrm{l}$; Invitrogen ${ }^{\mathrm{TM}}$ ) acrescido do siBMPRII, também diluídos em $50 \mu \mathrm{L}$ de meio Opti-MEM®. Após 5 minutos de incubação separadamente, à temperatura ambiente, a solução $A$ foi adicionada e levemente misturada à solução $B$. A solução final foi incubada por um período de 25 minutos à temperatura ambiente, a fim de permitir a formação dos complexos lipossoma-ácidos nucléicos. A seguir, os $100 \mu \mathrm{L}$ da solução final foram adicionados aos seus respectivos grupos de CG, contendo $200 \mu \mathrm{L}$ DMEM sem aditivos em cada poço. Como controles, foram utilizados três grupos de CG não expostos às drogas, cultivados em meio DMEM sem aditivos, meio DMEM acrescido do Opti-MEM (meio de diluição dos reagentes de lipofecção) ou em meio convencional DMEM completo, a fim de averiguar possíveis efeitos dos diferentes meios sobre o cultivo de CG. Abaixo se encontra uma representação esquemática do procedimento de silenciamento gênico por lipofecção em cultivo primário de células (Figura 20). 


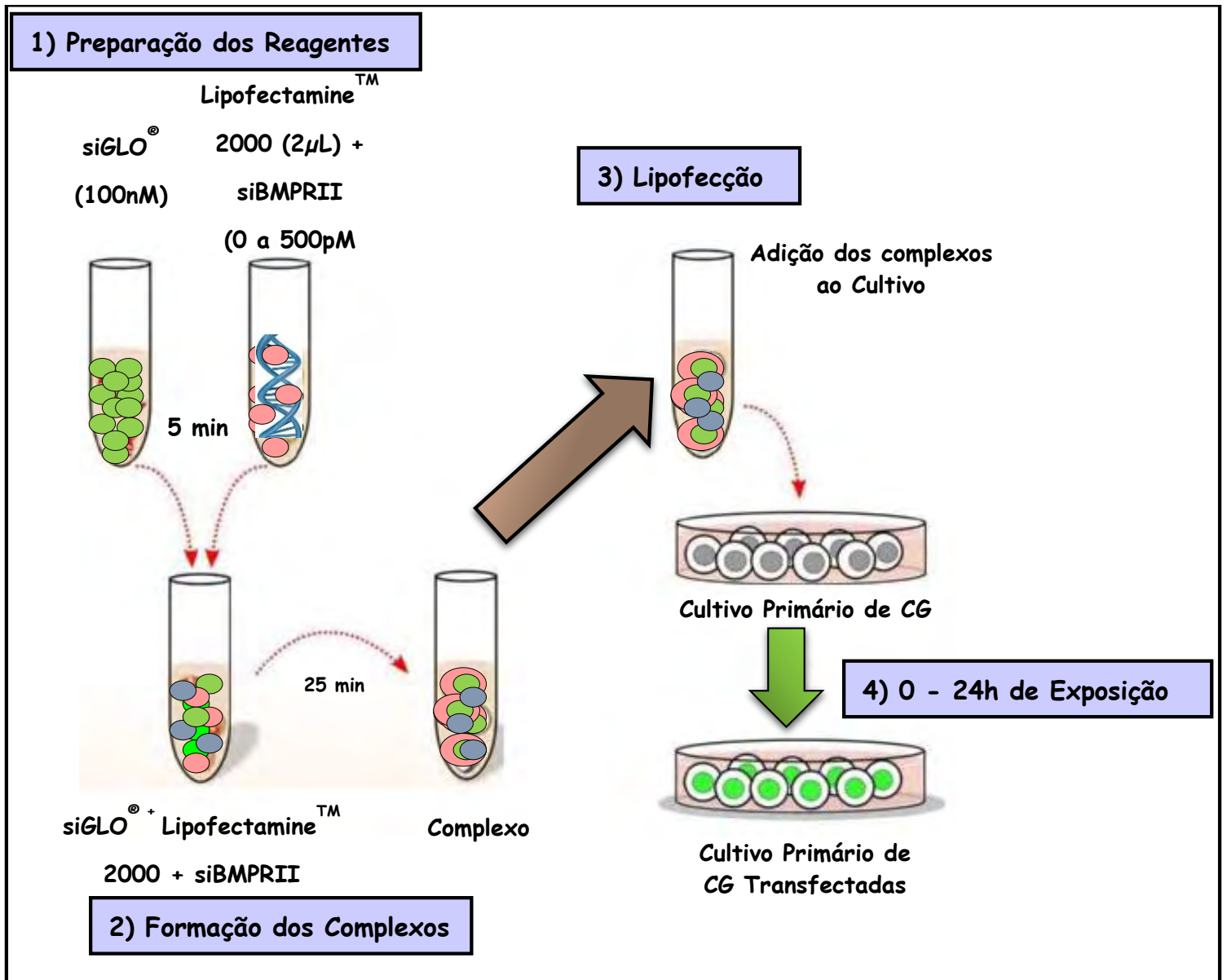

Figura 20. Representação esquemática do procedimento de lipofecção em cultivo primário de CG bovinas.

\subsubsection{Diferentes concentrações de siRNA para o silenciamento gênico} do BMPRII

Os grupos de CG, após atingirem 80 a 90\% de confluência, foram submetidos a diferentes concentrações do siBMPRII (0, 100, 200300400 e 500 pM), complexados aos lipossomas do reagente comercial Lipofectamine ${ }^{\mathrm{TM}} 2000(2 \mu \mathrm{L})$ e acrescidos do marcador de transfecção siGLO ${ }^{\circledR}$. As placas Nunc ${ }^{\circledR}$ de 4 poços, foram então cultivadas em estufa a $38,5^{\circ} \mathrm{C}$ em $5 \%$ de $\mathrm{CO}_{2}$ em ar por um período de 24 horas. Após esse período, as CG foram analisadas quanto à expressão de transcritos para BMPRII por PCR em tempo real. 


\subsubsection{Diferentes períodos de incubação com o siRNA para o} silenciamento gênico do BMPRII

Após avaliação da abundância relativa de RNAm do BMPRII, por PCR em tempo real, nos grupos de CG submetidas à exposição de diferentes concentrações de siBMPRII, a concentração que proporcionou uma redução mais expressiva dos transcritos foi utilizada para a determinação do tempo mínimo de cultivo requerido para se obter a máxima eficiência no processo de silenciamento gênico do BMPRII. Os grupos de CG foram então cultivados com esta concentração ótima de siBMPRII (100 pM) por períodos de $0,6,12,18$ e $24 \mathrm{~h}$ em estufa a $38,5^{\circ} \mathrm{C}$ em $5 \%$ de $\mathrm{CO}_{2}$ em ar e, posteriormente, avaliados quanto à abundância relativa de transcritos de BMPRII por PCR em tempo real.

\subsubsection{Avaliação visual da eficiência de lipofecção}

Antes de proceder com a coleta dos grupos de CG, os mesmos eram avaliados quanto à eficiência de lipofecção, verificada visualmente pela proporção subjetiva de CG apresentando fluorescência (indicativo da penetração do agente lipofector Lipofectamine $^{\mathrm{TM}} 2000$ com o marcador $\mathrm{SiGLO}^{\circledR}$ ) e por sua intensidade, através de microscopia de epifluorescência. As células ainda foram avaliadas visualmente quanto à integridade do cultivo e proporção de células degeneradas. Em caso de ineficiência da técnica de lipofecção, demostrada pela ausência de fluorescência, ou em caso de elevados índices de degeneração celular, os cultivos de CG foram descartados e novas repetições foram realizadas.

\subsubsection{Coleta e processamento das amostras de células da granulosa}

Após os diferentes períodos de cultivo in vitro a que os grupos experimentais de CG foram submetidos, os meios de cultivo foram removidos e as células lavadas com PBS livre de cálcio e magnésio. Após a completa remoção dos meios, as CG foram separadas com uma solução de $0,05 \%$ de Tripsina e $0,02 \%$ EDTA em PBS, lavadas duas vezes por centrifugação (20 min a 980 x $g$ a $4^{\circ} \mathrm{C}$ ) em PBS livre de cálcio e magnésio e, após a última lavagem, o pellet de CG foi acrescido de $1,5 \mu \mathrm{L}$ de uma solução de PBS contendo RNAseOUT® (1 UI/ $\mu \mathrm{L}$; RNAseOUT ${ }^{\mathrm{TM}}$ Recombinant Ribonuclease Inhibitor, 
Invitrogen ${ }^{\mathrm{TM}}$ ). Essas amostras foram imersas em $\mathrm{N}_{2}$ líquido e congeladas a $-80^{\circ} \mathrm{C}$ para posterior extração do RNA e quantificação dos transcritos de BMPRII por PCR em tempo real. Foram realizados cinco repetições de cada tratamento.

\subsubsection{Extração do RNA total pelo método de Trizol®}

Para detecção dos transcritos, as amostras de CG foram submetidas à extração de RNA segundo o protocolo de Trizol® $\left(\right.$ Invitrogen $^{\mathrm{TM}}$ ). A amostra foi homogeneizada com $110 \mu \mathrm{L}$ de uma solução contendo $100 \mu \mathrm{L}$ de Trizol®, $1 \mu \mathrm{L}$ de acrilamida linear (Ambion®, $5 \mathrm{mg} / \mathrm{mL}$ ) e $9 \mu \mathrm{L}$ de água ultapura tratada com DEPC e incubadas por 5 minutos a temperatura ambiente. Após esse procedimento, adicionou-se $20 \mu \mathrm{L}$ de clorofórmio (Synth) e incubou-se por um período de 3 minutos a temperatura ambiente. A amostra foi centrifugada a $12.000 \times \mathrm{g}$ por 15 minutos a $4^{\circ} \mathrm{C}$. O RNAfoi retirado $(70$ $\mu \mathrm{L}$ ) da fase aquosa e precipitado com $70 \mu \mathrm{L}$ de álcool isopropílico (Synth) seguido de uma incubação por 10 minutos a temperatura ambiente e 20 minutos a $-20^{\circ} \mathrm{C}$ e posteriormente centrifugados a $12.000 \mathrm{x} g$ por 10 minutos a $4^{\circ} \mathrm{C}$. Após esse período, o sobrenadante foi descartado e o RNA lavado com $100 \mu \mathrm{L}$ de etanol (Synth) a $75 \%$ e, posteriormente, centrifugado a $7.500 \mathrm{x} g$ por 5 minutos a $4^{\circ} \mathrm{C}$. Ao final do procedimento de extração, as amostras de RNA total foram solubilizadas em $10 \mu \mathrm{L}$ de água ultrapura tratada com DEPC e tiveram suas concentrações mensuradas por espectrofotometria no equipamento NanoDrop® 2000 (Thermo Scientific).

\subsubsection{Digestão das amostras de RNA com DNAse I}

Para os subsequentes processos de digestão e reação de transcrição reversa, as amostras de CG tiveram seus volumes ajustados a fim de conter sempre 1.000 ng de RNA por amostra. Após ajustar o volume de cada amostra, sempre a $4^{\circ} \mathrm{C}$, foi realizado o procedimento de digestão com a enzima DNAse I - Amplification Grade® (Invitrogen). Cada amostra de RNA (1.000ng) foi tratada com $1 \mu \mathrm{L}$ da DNAse I $(1 \mathrm{U} / \mu \mathrm{L})$ acrescido de $1 \mu \mathrm{L}$ de tampão DNAse (Invitrogen ${ }^{\mathrm{TM}}$ ), $0,25 \mu \mathrm{L}$ de $\mathrm{RNAseOUT}^{\mathrm{TM}}$ (Invitrogen) e água ultrapura livre de DNAse e RNAse suficiente para completar um volume final de $10 \mu \mathrm{L}$. Essa solução foi mantida a temperatura ambiente por um período de 15 minutos e, em seguida, acrescida de $1 \mu \mathrm{L}$ de EDTA $(25 \mathrm{mM})$ e incubada a $70^{\circ} \mathrm{C}$ por 10 minutos para a 
inativação da DNAse. Após esse procedimento, as amostras de RNA foram imediatamente resfriadas a $4^{\circ} \mathrm{C}$ e submetidas à reação de transcrição reversa (RT).

\subsubsection{Reação de Transcrição Reversa (RT)}

Para a transcrição reversa (RT) e síntese do RNA complementar (cDNA), utilizou-se o kit "High Capacity cDNA Reverse Transcription" (Applied Biosystems ${ }^{\mathrm{TM}}$; Invitrogen $^{\mathrm{TM}}$. A cada amostra de RNA foram adicionados $10 \mu \mathrm{L}$ de uma solução contendo $2 \mu \mathrm{L}$ do buffer RT 10X, 0,8 $\mu \mathrm{L}$ do mix de nucleotídeos dNTP 25X (100nM), 2 $\mu \mathrm{L}$ de primers randômicos $10 \mathrm{X}, 3,95 \mu \mathrm{L}$ de água ultrapura tratada com $\mathrm{DEPC}, 0,25 \mu \mathrm{L}$ do inibidor RNAseOUT ${ }^{\mathrm{TM}}$ (Invitrogen) e, por fim, $1 \mu \mathrm{L}$ da enzima MultiScribe ${ }^{\circledR}$ Reverse Transcriptase $(50 \mathrm{U} / \mu \mathrm{L})$. A reação de cDNA foi realizada em termociclador (Eppendorf®), onde as amostra foram incubadas a $25^{\circ} \mathrm{C}$ por 10 minutos, aquecidas a 37 ${ }^{\circ} \mathrm{C}$ por 2 horas e, posteriormente, a $85^{\circ} \mathrm{C}$ por 5 minutos. Ao final desse ciclo, as amostras de cDNA obtidas foram resfriadas a $4{ }^{\circ} \mathrm{C}$, quantificadas pelo equipamento NanoDrop ${ }^{\circledR}$ 2000 (Thermo Scientific) para verificação de sua integridade e, por fim, acondicionadas a $-20^{\circ} \mathrm{C}$ para posterior mensuração dos transcritos por PCR em Tempo Real.

\subsubsection{Investigação da expressão gênica por PCR em tempo real}

Após a síntese de cDNA, os produtos foram submetidos à amplificação por PCR (reação em cadeia de polimerase) em tempo real para a avaliação da expressão gênica e quantificação relativa do RNAm, tanto para o gene alvo BMPRII, como para os genes endógenos PPIA e $\beta$-Actina. Para tal, utilizou-se o sistema de detecção SybrGreen ${ }^{\circledR}$ seguindo as recomendações do fabricante, em equipamento da Applied Biosystems 7500 RT-PCR System. Nas reações para a quantificação dos genes BMPRII, PPIA e $\beta$-Actina, foram utilizados oligonucleotídeos iniciadores (primers) desenhados a partir de seqüências bovinas disponíveis no banco de dados GenBank e sintetizados pela Sigma Aldrich $\AA(P P I A \quad E \quad \beta$-Actina) ou Invitrogen (BMPRII). As sequências dos oligonucleotídeos iniciadores, utilizados na quantificação dos referidos genes, estão apresentadas na Tabela 4. 
Tabela 4. Sequência dos oligonucleotídeos iniciadores utilizados para a quantificação relativa dos genes PPIA, $\beta$-Actina e BMPRII.

\begin{tabular}{|c|c|}
\hline Genes & $\begin{array}{l}\text { Sequência de Nucleotídeos } \\
\qquad\left(5^{\prime}-3^{\prime}\right)\end{array}$ \\
\hline \multirow[t]{2}{*}{ PPIA } & F 5'- GCCATGGAGCGCTTTGG \\
\hline & R 5'- CCACAGTCAGCAATGGTGATCT \\
\hline \multirow[t]{2}{*}{ B-Actina } & F 5'-GGCACCCAGCACAATGAA-GA \\
\hline & R 5'- GCCAATCCACACGGAGTA \\
\hline \multirow[t]{2}{*}{ BMPRII } & F 5'-AGACTGTTGGGACCAGGATG \\
\hline & R 5'- GGATTGACTGTTGGGCTCAC \\
\hline
\end{tabular}

A técnica de PCR em tempo real foi primeiramente testada e padronizada em amostras de cDNA de células da granulosa, a fim de se obter máxima eficiência de amplificação para cada gene. Para tal padronização, foram realizados testes simples de amplificação com amostras de cDNA de CG sem tratamento e submetidas a diferentes períodos de cultivo $(24,48$ e $72 \mathrm{~h}$ ), para padronizar a técnica e avaliar o comportamento gênico temporal do BMPRII e dos endógenos nessas células somáticas. Após a efetivação dos testes, procedeu-se com a análise dos diferentes grupos experimentais de CG. Cada reação de amplificação foi preparada com $2 \mu \mathrm{L}$ de cDNA, 200nM de cada oligonucleotídeo iniciador (Foward e Reverse), $6 \mu \mathrm{L}$ de água ultrapura livre de DNAse e RNAse e $1 X$ do reagente Power SybrGreen ${ }^{\circledR}$ PCR Master Mix(Applied Biosystems ${ }^{\mathrm{TM}}$ ), garantindo um volume final de $20 \mu \mathrm{L} /$ reação. Para todos os genes referidos no presente experimento (BMPRII, PPIA e $\beta$-Actina), as condições de termociclagem para as reações de PCR em Tempo Real incluíram: desnaturação a $95^{\circ} \mathrm{C}$ por 10 minutos e 45 ciclos de $95^{\circ} \mathrm{C}$ por 15 segundos, $57^{\circ} \mathrm{C}$ por 20 segundos e $60^{\circ} \mathrm{C}$ por 40 segundos. A curva de dissociação foi iniciada em $60^{\circ} \mathrm{C}$ com $+0,1^{\circ} \mathrm{C}$ de incremento até atingir $95^{\circ} \mathrm{C}$. Cada amostra foi sempre avaliada em duplicata para cada um dos genes. Como controles 
negativos da reação, utilizou-se água ultrapura livre de DNAse e RNAse em substituição ao cDNA.

\subsubsection{Análise dos dados obtidos por PCR em tempo real}

Primeiramente, para a avaliação da eficiência e validação dos oligonucleotídeos iniciadores, referentes aos genes BMPRII, PPA e $\beta$-Actina, foram realizadas curvaspadrão de expressão gênica com amostras de cDNA de CG sem tratamento algum, ou seja, não expostas às drogas de silenciamento. Essas curvas-padrão continham cinco diluições seriadas (1:2 a 1:512), mantendo sempre uma razão geométrica 1:4. A partir da inclinação da curva ou "slope" foi possível obter a eficiência de amplificação em cada um dos genes estudados, a partir de análise no próprio equipamento da Applied Biosystems 7500 RT-PCR System. Após essa avaliação individual, foi averiguada a eficiência do gene alvo BMPRII em comparação com os genes endógenos (PPIA e $\beta$-Actina), avaliação esta também realizada pelo próoprio equipamento. Sendo comprovada uma eficiência elevada e equivalente para todos os genes, procedeu-se com as análises por PCR em tempo real das amostras de cDNA referentes aos diferentes grupos experimentais.

Os valores de expressão do gene alvo BMPRII foram normalizados pela expressão dos endógenos constitutivos PPIA e $\beta$-Actina. As diferenças nas frequências dos transcritos referentes aos três genes (PPIA, $\beta$-Actina e BMPRII) foram calculadas pelo método comparativo descrito por Livak, do $2^{-\Delta \Delta \mathrm{Ct}}$ (LIVAK; SCHMITTGEN, 2001). Para isso, primeiramente realizou-se a média das duplicatas referentes a cada amostra de cDNA e, posteriormente, calculou-se a diferença entre a média dos CTs do gene alvo (BMPRII) e a média dos Cts dos genes endógenos (PPIA e $\beta$-Actina) ( $\Delta \mathrm{Ct}$ ). Após isso, fez-se a média dos $\Delta \mathrm{Ct}$ para o grupo controle ( $\Delta \mathrm{Ct}$ médio) e calculou-se a diferença entre este e o $\Delta C t$ de cada amostra. Após a realização desses cálculos, a análise foi finalizada com a fórmula $2^{-\Delta \Delta \mathrm{Ct}}$. Os dados foram normalizados com a média do controle para cada concentração e de tempo estudado. Para todos os genes avaliados no presente experimento, fixou-se a linha de "threshold" no ponto médio da amplificação exponencial, que foi de 0,3 tanto para os genes endógenos PPIA e $\beta$-Actina quanto para o alvo BMPRII. 


\subsubsection{Detecção da proteína por western blotting}

Após análise da abundância relativa de transcritos para BMPRII, por PCR em tempo real, a melhor concentração de siBMPRII (100 pM) e melhor tempo de incubação (12 e 24 h?), ou seja, as condições que proporcionaram uma redução mais expressiva dos transcritos, foram aplicadas a novos grupos de CG para análise por western blotting (WB), para a confirmação do silenciamento gênico do BMPRII também em termos de redução protéica. Para tal, cada grupo de CG $\left(5 \times 10^{4}\right)$ foi lisado com $100 \mu \mathrm{L}$ de solução de lise para extração protéica, constituída por $98 \mu \mathrm{L}$ de tampão RIPA (150 mM de $\mathrm{NaCl}$; $1 \%$ NP-40; 0,5\% de deoxicolato de sódio; $0,1 \%$ de SDS e 50 mM de Tris; pH 8,0; SigmaAldrich $\left.{ }^{\circledR}\right), 1 \mu \mathrm{L}$ de inibidor de protease (Sigma-Aldrich $\left.{ }^{\circledR}\right)$ e $1 \mu \mathrm{L}$ de inibidor de fosfatase (Sigma-Aldrich $\left.{ }^{\circledR}\right)$. O homogenato foi sonicado por aproximadamente 1 minuto e centrifugado por 20 minutos a 12.000 x $g$ a $4^{\circ} \mathrm{C}$. Posteriormente, o sobrenadante foi reservado e acondicionado a $-20^{\circ} \mathrm{C}$ para posterior análise por western blotting. As concentrações protéicas das amostras foram determinadas pelo espectrofotômetro FLUOstar OPTMA® ${ }^{\circledR}\left(\mathrm{BMG}^{*} \mathrm{LABTECH}\right)$, a partir de uma curva padrão de BSA (0 a $1000 \mu \mathrm{g} / \mathrm{mL}$ ), utilizando-se o reagente Quick Start ${ }^{\mathrm{TM}}$ Bradford Protein Assay (BIORAD), segundo recomendações do fabricante. Às amostras protéicas de CG, foram adicionadas 1:1 parte de tampão de amostra SDS (125 mM Tris-HCl; com 4\% p/v SDS; $20 \%$ v/v glicerol; 0,004\% azul de bromofenol; $10 \%$ v/v 2-mercaptoetanol; $\mathrm{pH}$ 6,8), as quais foram posteriormente fervidas a $95^{\circ} \mathrm{C}$ por 5 min para adequada desnaturação protéica. As proteínas foram separadas por eletroforese em gel de SDS-PAGE com 10\% de policacrilamida (LAEMMLI, 1970), utilizando-se $15 \mu \mathrm{g}$ de proteína total por poço. O sistema eletroforético (OWL; Thermo Scientific $®)$ foi submetido a uma corrente elétrica inicial de $80 \mathrm{~V}$ que, após 30 minutos, foi aumentada para $100 \mathrm{~V}$. A eletroforese, realizada em tampão de corrida Tris-HEPES-SDS (0,1M Tris, 0,1M HEPES, 3 mM SDS, pH 8; Thermo Scientific () por aproximadamente 3 horas. As proteínas foram eletrotransferidas para uma membrana de PVDF (Novex $\left.{ }^{\circledR}\right)$ utilizando-se um sistema de transferência úmido (OWL; Thermo Scientific®) em tampão de transferência (25 mM Tris, $192 \mathrm{mM}$ glicina, 20\% metanol e0,1\% SDS) utilizando uma corrente elétrica de $100 \mathrm{~V}$ por 5 horas a $4^{\circ} \mathrm{C}$. Após a transferência, a membrana foi incubada em uma solução de bloqueio, contendo 5\% de leite em pó desnatado em salina tamponada com Tris e 0,1\% de Tween- 
20 (TBS-T) sob branda agitação, por um período de 2 horas a temperatura ambiente. Após o bloqueio, a membrana foi lavada por 4 vezes de 10 minutos com solução TBS-T, a temperatura ambiente. Posteriormente, a membrana foi submetida à incubação com o anticorpo primário anti-BMPRII (goat polyclonal IgG; $200 \mu \mathrm{g} / \mathrm{mL}$; Santa Cruz Biotechnologies), diluído em TBS-T a uma proporção de 1:100, por um período de 12 horas a $4^{\circ} \mathrm{C}$ sob branda agitação. Após esse período, a membrana foi lavada novamente (4 x 10 minutos em TBS-T) e incubada com o anticorpo secundário (donkey anti-goat IgGHRP conjugated; $100 \mu \mathrm{g} / \mathrm{mL}$; Santa Cruz Biotechnologies), diluído numa proporção de 1:5000 em TBS-T, por um período de 2 horas sob temperatura ambiente. Depois de lavada novamente (4 x 10 min em TBS-T), a membrana foi incubada em $2 \mathrm{~mL}$ do reagente quimioluminescente Novex ${ }^{\circledR}$ ECL HRP (Invitrogen ${ }^{\mathrm{TM}}$ ) por 1 min e, posteriormente, exposta a filme de raio-X por 5-10 min. As bandas presentes no filme foram analisadas pelo software Image ${ }^{\circledR}$ para a análise de densitometria das mesmas. 


\subsubsection{Análise Estatística}

Para a análise estatística dos dados, foi realizado o teste de normalidade e homogeneidade de variâncias entre grupos, a partir da expressão dos controles endógenos (PPIA e $\beta$-ctina). Todas as análises foram feitas utilizando-se o programa GraphPad Prism ${ }^{\circledR}$ versão 5.0. Primeiramente, empregou-se o teste One-wey ANOVA, seguido de teste de Tukey, para averiguar possíveis diferenças estatísticas entre os três grupos controle empregados no presente experimento e escolher o mais fidedigno. A análise de variância (ANOVA) One-way foi também utilizada para testar os efeitos das diferentes concentrações de siBMPRII sobre a expressão do gene BMPRII nas células da granulosa, assim como dos diferentes períodos de cultivo com o siBMPRII sobre a expressão deste gene. Para ambos os casos, realizou-se ainda o pós-teste de Dunnet para comparação entre as médias dos grupos experimentais e o grupo controle. Nos grupos que apresentaram diferença significativa quando comparados aos controles, foi realizada uma nova análise estatística, empregando-se One-way ANOVA, seguido de teste de Tukey, a fim de estabelecer uma análise comparativa entre esses grupos e, assim, eleger o grupo experimental que proporcionou maior eficiência no processo de sileciamento por lipofecção. Para a análise de densitometria das bandas (western blotting), os valores médios, aferidos pelo programa Image $₫$, também foram submetidos à análise de variância (ANOVA), seguido de teste de Tukey para evidenciar diferenças entre os tratamentos. Os dados do presente experimento são apresentados como média \pm EPM. Para todas as análises foi considerando um nível máximo de 5\% de significância $(\mathrm{p}<0,05)$. 


\subsubsection{Delineamento Experimental}

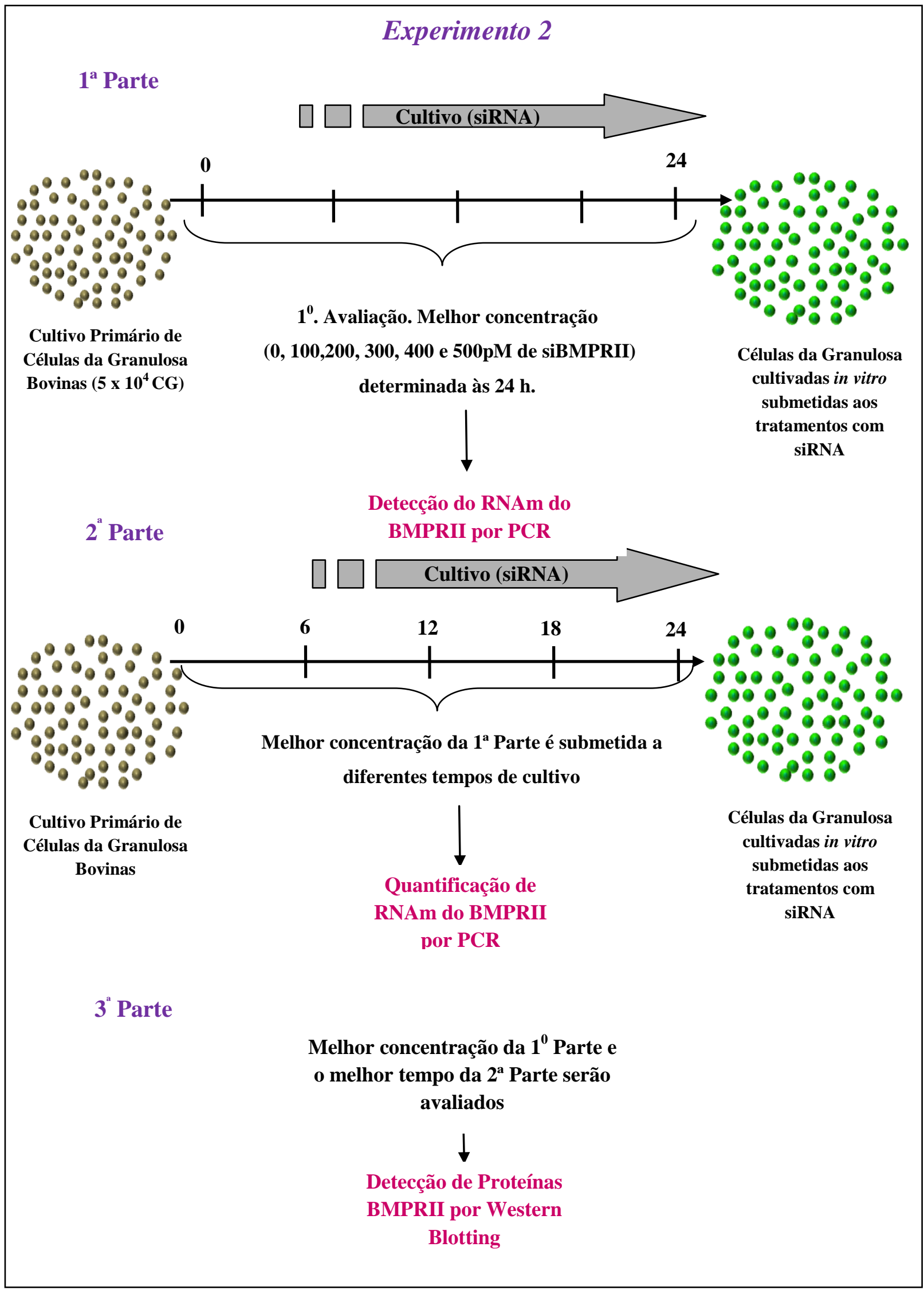

Figura 21. Representação esquemática do Experimento 2. 


\subsection{Resultados}

\subsubsection{Avaliação da eficiência dos genes endógenos e determinação da} melhor diluição para as amostras de cDNA

Anteriormente à análise dos diferentes grupos experimentais de células da granulosa, os oligonucleotídeos iniciadores (primers), referentes aos genes BMPRII, PPIA e $\beta$-Actina, foram avaliados quanto à sua eficiência de amplificação. As curvaspadrão de expressão gênica, realizadas com amostras de cDNA de CG sem tratamento algum e diluídas em série, mantendo uma razão geométrica de 1:4, possibilitou a avaliação da eficiência de cada um dos primers individualmente, assim como da eficiência conjunta do alvo BMPRII em comparação com os endógenos PPIA e $\beta$ Actina, constatando-se sempre uma elevada eficiência para todos eles. Portanto, todos os oligonucleotídeos utilizados no presente trabalho foram validados com uma elevada eficiência individual, avaliada em 93,4\% para o gene BMPRII, 99,4\% para o gene $\beta$ Actina e 90\% para o gene PPIA, e conjunta para os três genes, avaliada em (90\%) (Figura 22). A partir desses dados, foi possível estabelecer o PPIA e a $\beta$-Actina como os genes endógenos constitutivos como sendo adequados para a execução das análises do presente experimento. 


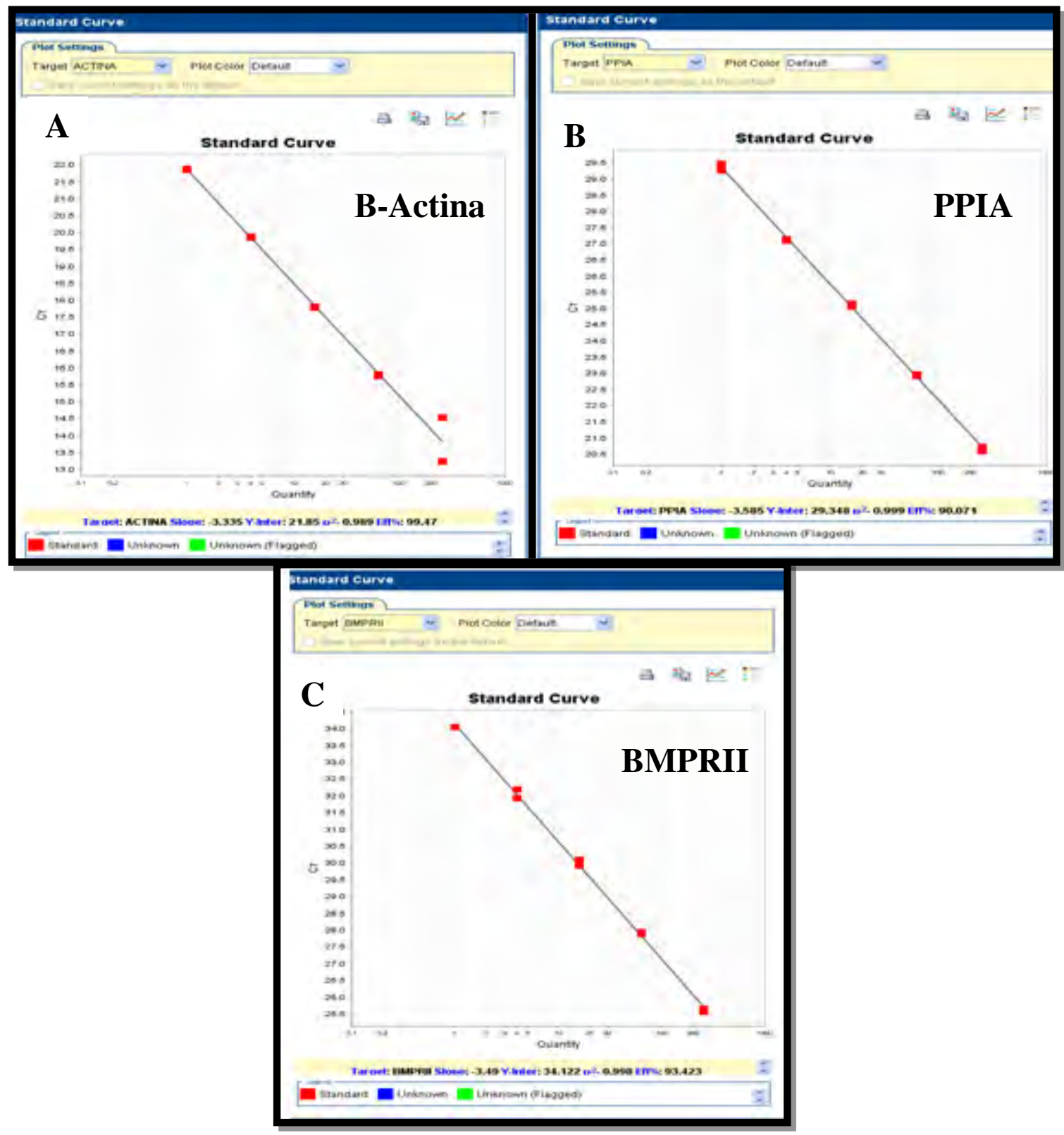

Figura 22. Eficiências de amplificação. Em A, B e C estão representadas as eficiências individuais para os genes $\beta$-Actina $(99,47 \%)$, PPIA (90\%) e BMPRII $(93,4 \%)$.

Como todos os ensaios realizados no presente trabalho são feitos em função do silenciamento do gene BMPRII e visto que este gene já é amplificado bem afrente dos controles endógenos, optou-se por adotar amostras de cDNA menos diluídas para se proceder com as análises de expressão gênica por PCR em tempo real. Como as amostras de cDNA se comportaram de maneira bastante semelhante para todas as diluições, referentes aos cinco pontos da curva-padrão, optou-se por adotar a mais concentrada 
delas, ou seja, a diluição de 1:2, que foi estabelecida como padrão para o presente estudo, a qual proporcionou uma elevada quantidade de trascritos, além de maior precocidade de amplficação.

\subsubsection{Expressão Temporal do BMPRII}

Anteriormente à realização dos ensaios de silenciamento gênico, procedeu-se com o desenvolvimento de um experimento de expressão temporal do gene BMPRII nas células da granulosa, a fim de padronizar a técnica de PCR em tempo real e conhecer o comportamento desse gene nas células da granulosa ao longo de um período de 24 horas, período este proposto para iniciar os ensaios de silenciamento gênico por lipofecção. Os grupos de CG submetidos a diferentes períodos de cultivo (0, 6, 12, 18 e 24 horas) em meio convencional (DMEM completo) sem nenhum tratamento, foram analisados quanto à expressão temporal do gene BMPRII e, a partir desses ensaios, foi possível constatar que, ao longo de um período de 24 horas de cultivo in vitro, a expressão do gene BMPRII se manteve constante, não diferindo estatisticamente $(p>0,5)$ ao longo desse período (Figura 23). A partir desses resultados, foi possível concluir que os experimentos de silenciamento gênico do BMPRII em células da granulosa bovinas, poderiam ser efetuados com sucesso, visto que a expressão deste gene em condições normais de cultivo, não sofre efeito negativo ao longo de um período de 24 horas. 


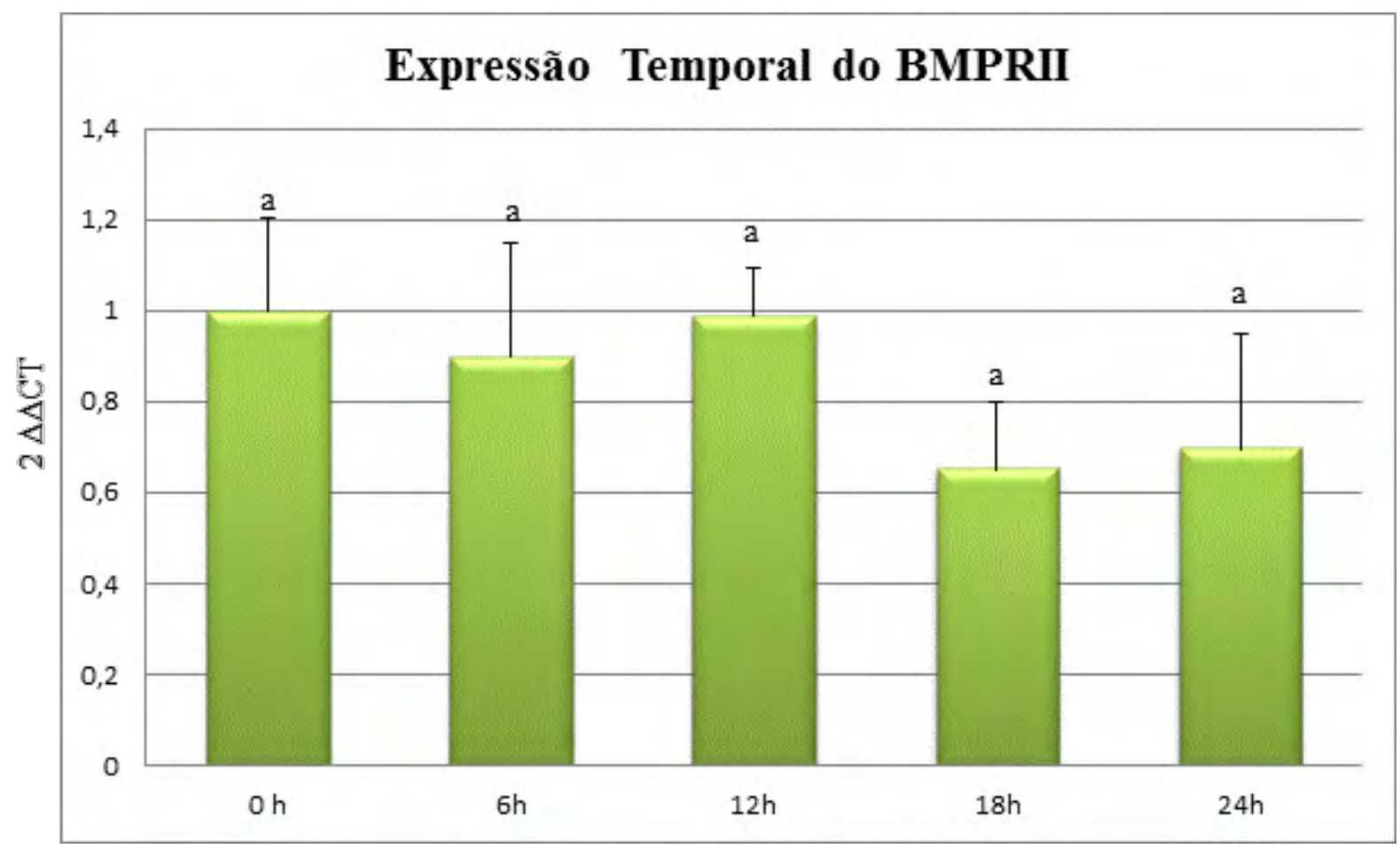

Figura 23. Valores médios (normalizados) de expressão gênica do BMPRII, determinados por $2 \Delta \Delta \mathrm{CT}$, referentes aos diferentes aos grupos de $\mathrm{CG}$ submetido à diferentes períodos de cultivo in vitro $(0,6,12,18$ e 24 h) em meio convencional (DMEM com aditivos). Os dados são apresentados como média $( \pm \mathrm{EP})$ e as letras iguais representam a ausência de diferença significativa entre os diferentes períodos $(\mathrm{p}>0,05)$.

\subsubsection{Análise dos diferentes controles}

Os três controles utilizados ao decorrer da técnica de silenciamento gênico, incubados em diferentes meios de cultivo (DMEM + Opti-MEM, DMEM - Opti-MEM e DMEM convencional com aditivos) por um período de 24 horas, a fim de se averiguar possíveis efeitos dos mesmos sobre o cultivo e expressão gênica das CG, foram inicialmente submetidos à uma análise visual da integridade celular e, posteriormente, a uma análise por PCR em tempo real da expressão gênica do BMPRII. Quanto à integridade do cultivo e índice de degeneração celular, avaliados visualmente, não foram observadas diferenças entre os grupos. Em relação às médias de expressão gênica do BMPRII (abundância relativa dos transcritos), determinadas a partir de PCR em tempo real, averiguou-se que os grupos controle não diferiam significativamente entre si $(\mathrm{p}>0,05)$ (Tabela 5 e Figura 24). 
Tabela 5. Médias ( \pm EP) de expressão gênica $(2 \Delta \Delta \mathrm{CT})$ do BMPRII referentes aos diferentes grupos controle de CG, determinadas por PCR em tempo real.

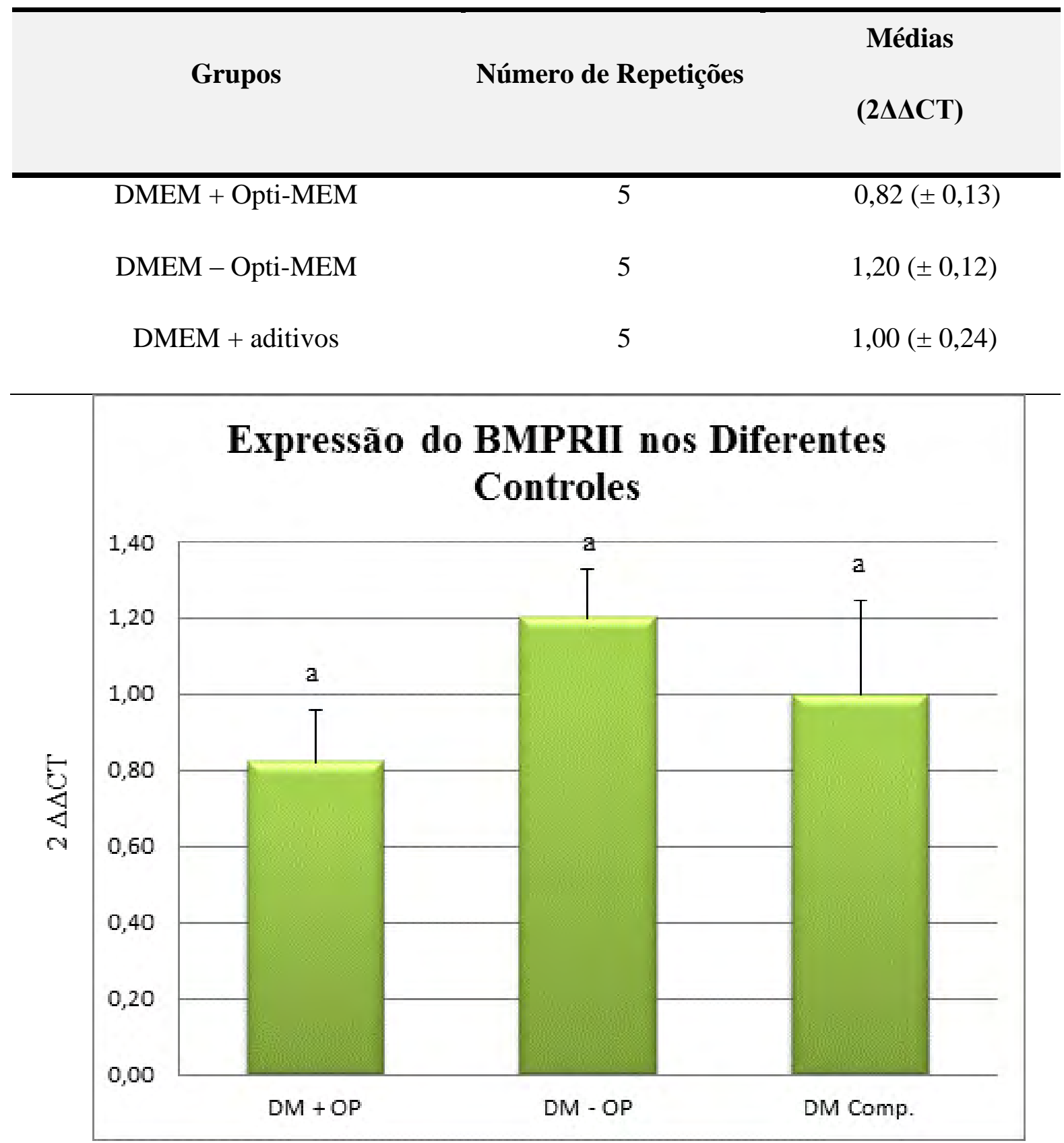

Figura 24. Valores médios (normalizados) de expressão gênica do BMPRII, determinados por $2 \Delta \Delta \mathrm{CT}$, referentes aos diferentes grupos controle de CG. Os dados são apresentados como média $( \pm \mathrm{EP})$ e as letras iguais representam a ausência de diferença significativa entre os grupos 0pM, DMEM sem aditivos e DMEM completo ( $p>0,05)$.

Visto que os diferentes meios de cultivo não proporcionaram diferenças significativas em relação à expressão do gene alvo BMPRII, adotou-se um único grupo controle para o desenvolvimento dos experimentos seguintes, sendo este o que representa 
mais fielmente o meio de cultivo dos grupos experimentais de CG, correspondendo a DMEM acrescido de Opti-MEM, nas mesmas proporções que os demais grupos

\subsubsection{Determinação da melhor concentração de siBMPRII às 24} horas de cultivo

Os grupos de CG submetidos à exposição de diferentes concentrações do siBMPRII (0, 100, 200300400 e 500 pM), foram primeiro analisados visualmente quanto à eficiência de lipofecção, verificada pela proporção subjetiva de CG apresentando fluorescência, através de microscopia de epifluorescência e ainda quanto à integridade do cultivo e proporção de células degeneradas. Na grande maioria dos ensaios de lipofecção, realizados no presente experimento, a eficiência mostrava-se sempre bastante elevada, em torno de 80 a $90 \%$, comprovando o sucesso da técnica utilizada. Nos raros casos em que havia reduzida eficiência da técnica de lipofecção, demostrada pela baixa fluorescência, ou em caso de elevados índices de degeneração celular, os cultivos de CG foram descartados e novas repetições foram realizadas. Após análise visual dos cultivos, os grupos de CG foram coletados e analisados quanto à expressão relativa do gene alvo BMPRII, assim como dos endógenos PPIA e $\beta$-Actina, por PCR em tempo real.

A partir das análises realizadas por PCR em tempo real das diferentes amostras de células da granulosa, foi possível constatar que, todas as concentrações de siBMPRII proporcionaram semelhante redução dos transcritos, não diferindo estatisticamente entre si ( $>0$,05). Entretanto, quando comparados aos grupos controle, não expostos às drogas de silenciamento gênico, foi observada uma redução bastante significativa na expressão do gene alvo BMPRII ( $\mathrm{p}<0,001)$ (Tabela 6 e Figura 25). Assim, todas as concentrações analisadas nesta etapa proporcionaram elevada eficiência de silenciamento gênico, evidenciada por uma redução de, aproximadamente, $88 \%$ dos transcritos quando comparados aos grupos controle não expostos ao agente silenciador siBMPRII. 
Tabela 6. Médias ( $\pm \mathrm{EP})$ de expressão gênica $(2 \Delta \Delta \mathrm{CT})$ do BMPRII, referentes aos grupos de CG submetidos à diferentes concentrações do siBMPRII $(0,100,200,300$, 400, 400 e 500pM), determinadas por PCR em tempo real.

\begin{tabular}{ccc}
\hline Grupos & Número de Repetições & Médias \\
\hline 0pM siBMPRII & 5 & $(\mathbf{2} \Delta \mathbf{\Delta C} \mathbf{T})$ \\
100pM de siBMPRII & 5 & $1,00( \pm 0,23)$ \\
200pM de siBMPRII & 5 & $0,14( \pm 0,03)$ \\
300pM de siBMPRII & 5 & $0,15( \pm 0,05)$ \\
400pM de siBMPRII & 5 & $0,12( \pm 0,04)$ \\
500pM de siBMPRII & 5 & $0,19( \pm 0,11)$ \\
\end{tabular}

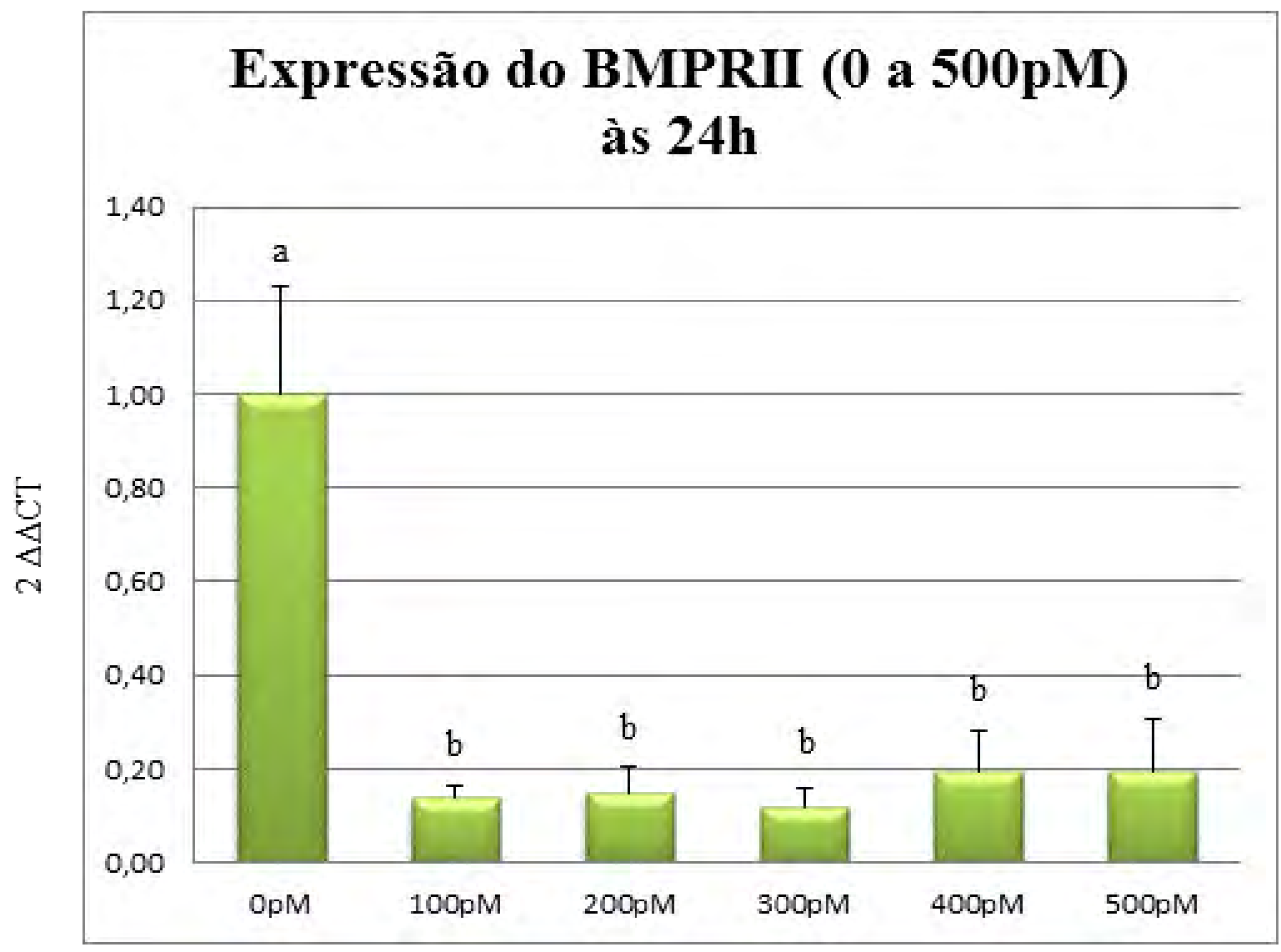

Figura 25. Valores médios (normalizados) de expressão gênica do BMPRII, determinados por 2 $\Delta \Delta \mathrm{CT}$, referentes aos grupos de CG submetidos à diferentes concentrações do siBMRII $(0,100$, 
200, 300, 400 e 500 pM) por um período de 24 horas. Os dados são apresentados como média $( \pm \mathrm{EP})$ e as letras diferentes representam diferença estatística significativa $(\mathrm{p}<0,001)$.

Visto que as diferentes concentrações de siBMPRII proporcionaram uma redução de transcritos bastante semelhante às 24 horas de cultivo in vitro, não havendo diferença estatística entre eles, optou-se pela menor concentração (100pM), a fim de a otimizar a utilização do agente de silenciamento siBMPRII e evitar possíveis danos celulares.

\subsubsection{Determinação do melhor período de incubação com 100 pM de} SiBMPRII

A partir da determinação da melhor concentração do siBMPRII (100pM) foi possível estabelecer o período mínimo de incubação necessário para se obter a máxima eficiência de silenciamento gênico por lipofecção do BMPRII em células da graulosa bovinas. Os grupos de CG foram cultivados com 100 pM de siBMPRII por períodos de 0 , $6,12,18$ e 24 h e avaliados quanto à abundância relativa de transcritos de BMPRII por PCR em tempo real. Foi possível constatar que todos os períodos de incubação com o siBMPRII proporcionaram semelhante redução dos transcritos para BMPRII, não diferindo estatisticamente entre si ( $p>0,05)$. Quando comparados ao grupo controle de 0 horas, não expostos às drogas de silenciamento gênico, foi observada uma redução significativa na expressão do gene alvo BMPRII $(\mathrm{p}<0,05)$. Reduções mais expressivas do gene BMPRII foram averiguadas às 18 e 24 horas de exposição aos 100 pM de siBMPRII $(\mathrm{p}<0,01)$ (Tabela 7 e Figura 26). Concluiu-se, portanto, que todos os períodos de exposição ao siBMPRII, foram capazes de proporcionar elevada eficiência de silenciamento gênico, evidenciada por uma redução de, aproximadamente, $77 \%$ dos transcritos quando comparados ao grupo controle não exposto ao agente silenciador siBMPRII e coletado às 0 horas de cultivo in vitro. 
Tabela 7. Médias ( $\pm \mathrm{EP})$ de expressão gênica $(2 \Delta \Delta \mathrm{CT})$ do BMPRII, referentes aos grupos de CG submetidos à incubação de 100pM de siBMPRII por diferentes períodos $(0,6,12,18$ e 24 horas $)$, determinadas por PCR em tempo real.

\begin{tabular}{ccc}
\hline Grupos & Número de Repetições & Médias \\
& 5 & $(\mathbf{2} \Delta \mathbf{\Delta} \mathbf{C} \mathbf{T})$ \\
\hline 0 Horas & 5 & $1,00( \pm 0,21)$ \\
$100 \mathrm{pM} 6$ horas & 5 & $0,26( \pm 0,14)$ \\
$100 \mathrm{pM} 12$ horas & 5 & $0,26( \pm 0,13)$ \\
$100 \mathrm{pM} 18$ horas & 5 & $0,21( \pm 0,15)$ \\
$100 \mathrm{pM} 24$ horas & & $0,17( \pm 0,10)$ \\
\hline
\end{tabular}

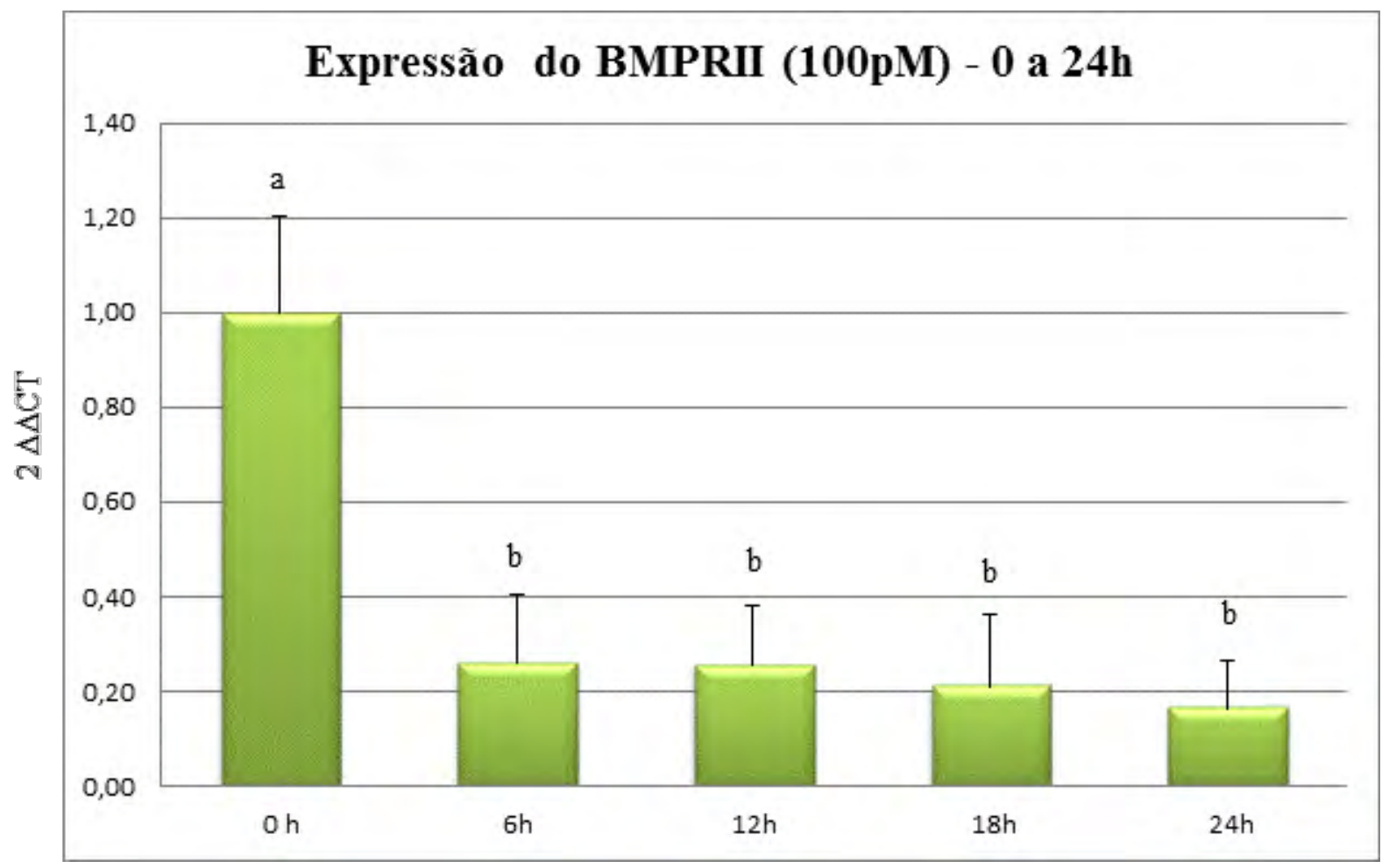

Figura 26. Valores médios (normalizados) de expressão gênica do BMPRII, determinados por 2 $\Delta \Delta \mathrm{CT}$, referentes aos grupos de CG submetidos à diferentes períodos de incubação $(0,6,12,18 \mathrm{e}$ 24 horas) com 100 pM de siBMPRII. Os dados são apresentados como média ( \pm EP) e as letras 
diferentes representam diferença estatística significativa entre os grupos experimentais e o controle $(0 \mathrm{~h})(\mathrm{p}<0,05)$.

A partir dos dados apresentados e visto que os diferentes períodos de incubação ao siBMPRII proporcionaram uma redução bastante semelhante na expressão gênica do BMPRII, adotou-se o período de 24 horas de exposição como ideal para a realização do procedimento de silenciamento gênico por lipofecção em células da granulosa bovinas.

\subsubsection{Detecção da proteína por western blotting}

Após o estabelecimento das condições ideais para o silenciamento gênico do BMPRII por lipofecção nas células da granulosa bovinas, otimizadas em 100 pM do agente de silenciamento siBMPRII e 24 horas de incubação, foi realizada a detecção da proteína BMPRII pela técnica de western blotting, para a confirmação do silenciamento gênico também em nível de expressão protéica. A partir da análise visual das revelações de western blotting, já foi possível notar uma considerável redução da proteína BMPRII (Figura 27). As revelações foram então submetidas à analise de densitometria de suas bandas e, a partir dessa, foi possível observar uma redução bastante expressiva e significativa da proteína BMPRII nos grupos expostos a $100 \mathrm{pM}$ de siBMPRII por um período de 24 horas ( $p<0,001$ ), quando comparados com o grupo controle de 0 pM de siBMPRII (Tabela 8 e Figura 28).

$\begin{array}{cccccc}1 & 2 & 3 & 4 & 5 & 6 \\ 0 \mathrm{pM} & 100 \mathrm{pM} & 0 \mathrm{pM} & 100 \mathrm{pM} & 0 \mathrm{pM} & 100 \mathrm{pM}\end{array}$

Figura 27. Imagem representativa da detecção das proteínas por western blotting de três repetições do experimento de silenciamento gênico. Estão representados três grupos de CG expostos à $100 \mathrm{pM}$ de siBMPRII (colunas 1,3 e 5) e três grupos expostos a 0 pM (linhas 2, 4 e 6), cultivados por um período de 24 horas. 
Tabela 8. Médias ( $\pm \mathrm{EPM})$ de densitometria das bandas proteicas detectadas por western blotting, referentes aos grupos de CG submetidos às melhores condições de silenciamento (100 pM de siBMPRII por 24 horas) e ao grupo controle ( 0 pM de siBMPRII por 24 horas).

\begin{tabular}{ccc}
\hline Grupos & Número de Repetições & Médias \\
& & (Pixels) \\
\hline 0 pM de siBMRII 24 horas & 3 & $1521,33( \pm 108,64)$ \\
100 pM siBMPRII 24 horas & 3 & $704,67( \pm 122,9)$ \\
\hline
\end{tabular}

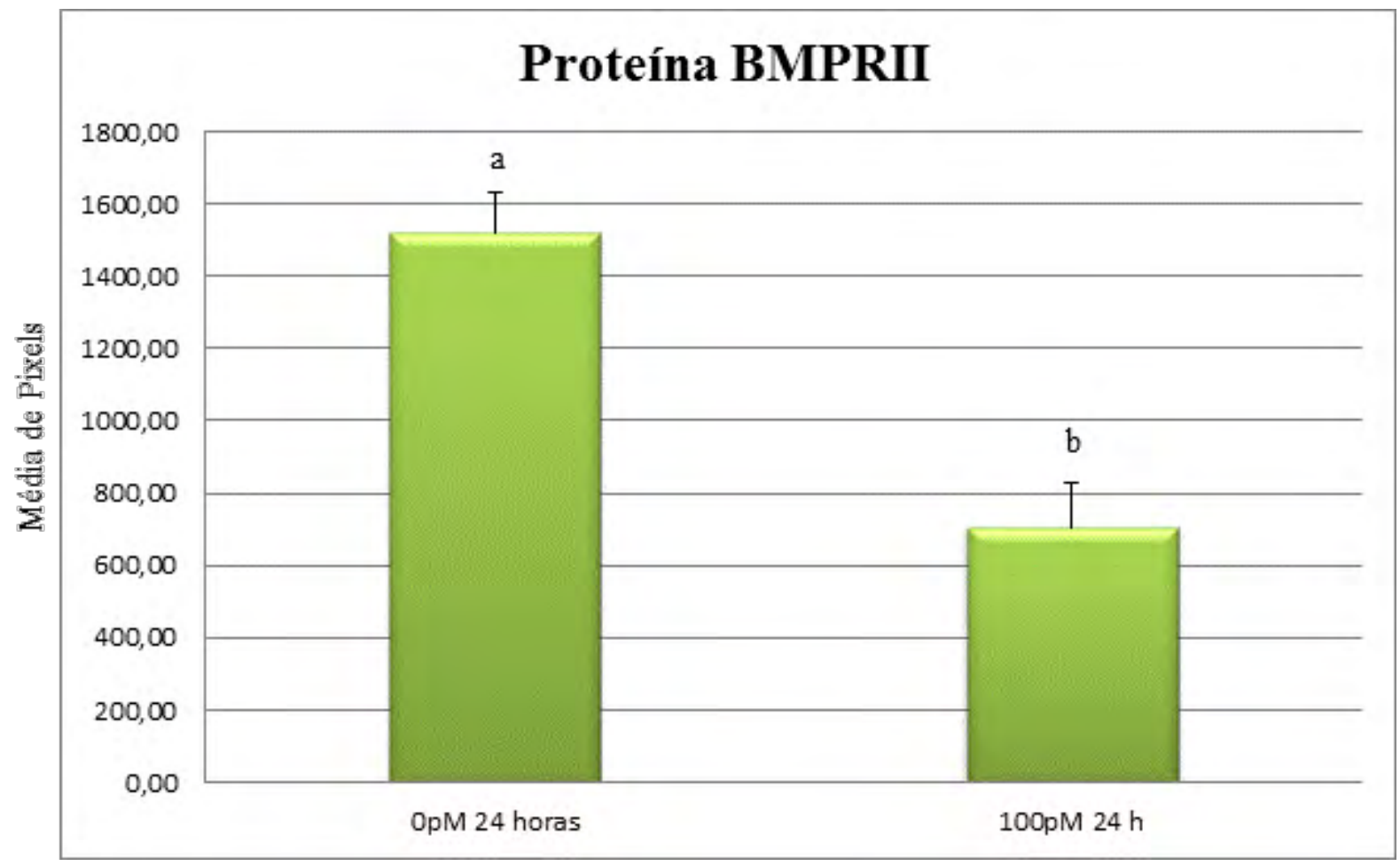

Figura 28. Valores médios de densitometria das bandas, referentes aos grupos de CG submetidos às melhores condições de silenciamento gênico (100 pM de siBMPRII por 24 horas) e ao controle. Os dados são apresentados como média $( \pm \mathrm{EPM})$ e as letras diferentes representam diferença estatística significativa entre o grupo experimental e grupo controle $(0 \mathrm{pM})(\mathrm{p}<0,001)$.

Os resultados obtidos a partir dos ensaios de western blotting, comprovam a eficiência alcançada pela metodologia de silenciamento gênico por lipofecção, desenvolvida para o gene BMPRII em células da granulosa bovinas no presente trabalho. 


\subsection{Discussão}

As células da granulosa são um dos constituintes do ambiente folicular de grande importância para a aquisição da competência oocitária, ovulação e fertilização em mamíferos, portanto, a complexa interação que ocorre entre o oócito e essas células somáticas, assim como sua influência na qualidade oocitária e embrionária, tem sido alvo de inúmeros estudos, mas muitas questões ainda necessitam ser esclarecidas, principalmente na espécie bovina (RICHARD e SIRARD, 1996). Assim, um melhor entendimento sobre essa interação, principalmente em relação aos possíveis genes e proteínas sintetizados pelas células do cumulus e envolvidos no processo de capacitação oocitária, torna-se crucial para a adequada regulação da maturação oocitária in vitro, a fim de possibilitar a total competência do oócito em suportar a embriogênese (CAIXETA et al. 2009; TESFAYE et al. 2009).

Atualmente, existe grande interesse no estudo de fatores parácrinos secretados por oócitos e seu papel na regulação dos processos-chave das células da granulosa. Grande parte desse interesse recente tem se concentrado nos fatores parácrinos pertencentes à superfamília TGF- $\beta$, principalmente em relação ao GDF9 e ao BMP15, visto que estes vêm se mostrado fundamentais para o desenvolvimento, diferenciação folicular e também para a maturação oocitária e ovulação, além de estarem intimamente relacionados à multiplicação, função e diferenciação das células da granulosa (YING et al., 2000). A atuação dos fatores GDF-9 e BMP15 nos processos citados é evidenciada por defeitos reprodutivos em animais que possuem mutações desses genes (revisado por MCNATTY et al., 2004) e pela habilidade das formas recombinantes dos mesmos em mimetizar as ações parácrinas do oócito sobre as células da granulosa e do cumulus em condições in vitro (revisado por GILCHRIST at al., 2004). O amplo interesse nesses fatores secretados pelo oócito surgiu não só pela necessidade de melhorar a nossa compreensão acerca dos mecanismos fundamentais reguladores da foliculogênese e da capacitação oocitária, mas também porque a expressão alterada desses fatores possui efeitos profundos sobre a função ovariana e fertilidade (GILCHRIST et al., 2008). Esses fatores parácrinos são então cruciais para manter a complexa função ovariana (VITT e HSUEH, 2001; WU e MATZUK, 2002) e a manutenção de níveis adequados de expressão do BMP15 e GDF9 nos oócitos, assim como a função de seus receptores e das vias de sinalização por eles ativadas nas células da granulosa, é essencial para a eficiência do desenvolvimento 
folicular, capacitação oocitária, ovulação, fertilização e, consequentemente, para elevar a fertilidade das fêmeas.

Embora haja um grande número de pesquisas envolvendo os fatores BMP15 e GDF9, os conhecimentos sobre seus papéis específicos na reprodução da fêmea bovina são ainda limitados. Desta forma, torna-se essencial a elucidação dos complexos mecanismos de atuação desses fatores, que pode ser estrategicamente realizada através do silenciamento gênico de seu receptor BMPRII.

Diante da importância das funções que os fatores GDF9 e BMP15 exercem sobre a função ovariana, e sabendo-se que o BMPRII consiste num receptor comum a esses dois fatores parácrinos, este foi selecionado como gene de interesse no presente estudo. Visto que a ação biológica desses fatores parácrinos ocorre apenas a partir da ligação com o receptor de membrana tipo II (BMPRII) localizado nas células da granulosa, o silenciamento deste receptor pode constituir uma importante ferramenta para o estudo das funções dos fatores GDF9 e BMP15 e, consequentemente, para elucidar a complexa interação existente entre os componentes do ambiente folicular.

Diante disso e sabendo-se que os lipossomas vêm sendo considerados o sistema de transfecção de siRNA mais eficiente e menos agressivo para os cultivos celulares, além de apresentarem fácil manipulação e não demandarem alto investimento, (OLIVEIRA et al., 2005), o presente tabalho teve como intuito principal desenvolver uma metodologia de silenciamento gênico por lipofecção em células da granulosa bovinas, a fim de se criar uma ferramenta eficiente e confiável para a investigação mais aprofundada de fatores derivados do oócito e, consequentemente, elucidar os processos desencadeados para a complexa interação oócito-células da granulosa.

Portanto, neste trabalho foram otimizadas as condições de silenciamento gênico e, para tal, inicialmente fez-se necessário a avaliação de diferentes grupos controle de CG, onde o intuito principal era averiguar possíveis interferências do meio sobre a expressão gênica do BMPRII. Ao avaliar três diferentes controles de CG, submetidos ao meio DMEM convencional com aditivos usuais de cultivo (soro, antibiótico e hormônios; controle positivo de cultivo), DMEM com o meio de diluição da lipofecção Opti-MEM (controle positivo do diluente do siRNA) e DMEM sem aditivos (controle negativo) foi possível constatar certa padronização comportamental entre os grupos, não havendo diferença significativa entre eles. Esses dados indicam que os diferentes meios de cultivo utilizados no decorrer do presente experimento não interferem na expressão gênica do 
BMPRII, sendo possível a eleição de qualquer um deles, visto que o efeito "meio" foi descartado a partir desses ensaios de análise comportamental. Assim sendo, pode-se admitir que qualquer efeito de redução de expressão do gene alvo foi ocasionado pelo tratamento e não por interferência de fatores outros (ou ausência deles) presentes no meio de cultivo.

Após a averiguar a inexistência de interferências dos diferentes meios, procedeuse com a realização de um experimento de expressão temporal do gene BMPRII que, ao ser avaliado de 6 em 6 horas em grupos de células da granulosa ao longo de um período total de 24 horas, apresentou um comportamento bastante estável, sem variações ao longo do tempo. Essa observação indica que a metodologia de silenciamento gênico pode ser eficientemente aplicada ao BMPRII para o estudo funcional do mesmo, visto que a expressão deste receptor não foi afetada, nem pelos diferentes tipos de meio utilizados, nem pelos diferentes períodos de cultivo a que foram submetidas. Essas observações estão de acordo com o trabalho de Lima e colaboradores (2012), que identificaram o mRNA do BMPRII em todos os estágios de desenvolvimento folicular. Outros autores também detectaram o BMPRII, tanto em termos de RNAm quanto de proteína em células da granulosa nos folículos de mamíferos em todos as categorias foliculares (WILSON et al., 2001; SOUZA et al., 2002; SILVA et al., 2006; LIMA et al., 2012). Ainda, segundo RUA et al. (2009), as células da granulosa cultivadas in vitro, mesmo durante o processo de luteinização, continuam expressando os receptores para BMPRII. Essas observações sugerem então que o BMPRII é um gene candidato adequado para esse tipo de estudo de silenciamento gênico por não ter a expressão afetada pelo tempo de cultivo, indicando que efeitos observados são devido ao tratamento de silenciamento e não a uma mera variação temporal.

Nos ensaios de determinação da melhor concentração de siBMPRII a ser utilizada no procedimento de silenciamento gênico, ou seja, da concentração que fosse capaz de reduzir mais eficientemente as quantidades de transcritos para o BMPRII às 24 horas de cultivo in vitro, houve uma certa equivalência em relação à redução do mRNA entre os diferentes tratamentos (100 a $500 \mathrm{pM})$ que, por outro lado, diferiram muito significativamente dos grupos controles não submetidos ao agente de silenciamento $(0$ pM de siRNA). Todas as concentrações foram capazes de proporcionar uma redução de aproximadamente $85 \%$ na expressão do gene BMPRII. Diante desse resultado, onde, contrariamente ao que se esperava, concentrações mais elevadas de siBMPRII não 
proporcionaram reduções mais expressivas dos transcritos, foi possível estabelecer como concentração ótima para o silenciamento gênico a menor delas, ou seja, de 100 pM de siBMPRII, possibilitando, dessa forma, custos mais baixos da técnica (usando menor quantidade de reagentes) aliados à uma elevada eficiência, além de evitar possíveis efeitos tóxicos das drogas utilizadas. Níveis semelhantes de SG $(80 \%)$ foram relatados por Kobayashi (2007) para o gene COX-2 em CG bovinas, porém com maiores concentrações de siRNA (250pM). Já Gao et al. (2009), relataram níveis inferiores (45\%) para o gene SMPE1 em CG humanas, utilizando 50nM do siRNA por um período de $6 \mathrm{~h}$. O’Meara e colaboradores (2011), por sua vez, relataram uma redução de 70\% do gene ECaderina em embriões bovinos, utilizando 20nM por um período de $1 \mathrm{~h}$.

Após a determinação da menor concentração de siBMPRII mantendo eficiência adequada às 24 horas de cultivo in vitro, os ensaios para determinar o melhor período de incubação com os 100 pM do siRNA (6 a 24 h), não mostraram diferenças em relação à expressão BMPRII entre os diferentes períodos de incubação com o siRNA. No entanto, assim como nas diferentes concentrações de siBMPRII, houve um decréscimo bastante considerável na quantidade de transcritos dos grupos experimentais de CG quando comparou-se aos grupos controle, submetidos à 0 hora de cultivo, ou seja, coletados anteriormente ao processo de lipofecção. Estes ensaios sugerem que o silenciamento do gene BMPRII já pode ser observado a partir de 6 horas de cultivo in vitro. No entanto, o silenciamento torna-se mais expressivo com o maior tempo de exposição ao agente de silenciamento, sendo averiguadas reduções mais intensas nas quantidades de transcritos com o passar do tempo, evidenciada por uma redução de até de $82 \%$ para o grupo de 24 horas. Diante disso, determinou-se como período ótimo de incubação com o agente de silenciamento o período de 24 horas, visto que este, além de proporcionar uma redução mais significativa dos transcritos sem afetar a viabilidade das células.

A detecção da proteína BMPRII traduzida a partir dos transcritos do gene estudado, também foi avaliada para confirmar a eficiência da técnica de silenciamento gênico A partir dos resultados foi possível constatar uma expressiva redução da proteína BMPRII, comprovando de maneira evidente a eficiência da metodologia desenvolvida no presente trabalho para silenciar o gene BMPRII por lipofecção em células da granulosa bovinas. Resultados semelhantes, porém estudando outro gene, também foram observados por Kobayashi et al. (2007) em CG bovinas. Embora existam poucos estudos de silenciamento gênico por lipofecção em CG bovinas, nossos resultados e dos referidos 
autores, indicam que tal metodologia é viável e tem potencial de se tornar uma importante ferramenta para estudo funcional de genes conhecidos ou de função ainda não determinada nesse tipo celular.

Diante dos resultados obtidos no presente trabalho foi possível desenvolver com sucesso uma metodologia eficiente e confiável de silenciamento gênico pela técnica de RNAi mediada por moléculas de siRNA internalizadas por lipossomas. Visto que ainda não existe um protocolo bem estabelecido para tal, esta metodologia poderá ser utilizada como ferramenta para investigação do papel do BMPRII no ambiente folicular e, consequentemente, determinar com mais precisão a importância funcional dos fatores GDF9 e BMP15 para a função das CG e suas consequências sobre o desenvolvimento do gameta feminino. Esta metodologia poderá ainda ser utilizada na investigação do papel de outros genes expressos nas células da granulosa bovinas e que possam ser importantes para o adequado funcionamento do oócito, elucidando assim, as vias de sinalização envolvidas na interação entre as células somáticas e o oócito. A melhor compreensão acerca dessa comunicação é de fundamental importância para o aprimoramento do cultivo de oócitos in vitro, tornando-o mais eficiente em simular o microambiente folicular natural do gameta e, consequentemente, para o incremento das taxas de eficiência em técnicas reprodutivas como a fertilização e a produção de embriões in vitro (PIV e FIV). 
CAPÍTULO VI

Conclusões 


\section{CONCLUSÕES}

A lipofecção foi eficiente e adequada para a introdução do siRNA em CG bovinas;

O BMPRII é expresso de modo estável ao longo do cultivo in vitro das CG bovinas, sendo um alvo adequado para o silenciamento gênico;

O siBMPRII induziu eficientemente a redução do transcrito e da proteína do gene alvo sem causar danos às células;

Há necessidade de estabelecer as condições de silenciamento (concentração do siRNA e tempo de incubação) antes de sua utilização;

As condições de silenciamento gênico pela técnica de RNAi estabelecidas no presente trabalho, poderão ser aplicadas para o estudo funcional do BMPRII em CG bovinas e potencialmente também para o estudo de outros genes de interesse, mediante as padronizações requeridas. 
CAPÍTULO VII

\section{Referências Bibliográficas}




\section{REFERÊNCIAS}

Agrawal, N., Dasaradhi, P.V.N., Mohmmed, A., Malhotra, P., Bhatnagar, R.K., and Mukherjee, S.K. RNA interference: biology, mechanism, and applications. Microbiology Mol. Biol. Rev. 67, 657-685, 2003.

AALTONEN, J., LAITINEN, M. P., VUOJOLAINEN, K., JAATINEN, R., HORELLIKUITUNEN, N., SEPPA, L., LOUHIO, H., TUURI, T., SJOBERG, J., BUTZOW, R., HOVATTA, O., DALE, L., RITVOS, O. Human growth differentiation factor 9 (GDF-9) and its novel homolog GDF-9B are expected in oocytes during early folliculogenesis. Journal of Clinical Endocrinology and Metabolism, v. 84, p. 2744-2750, 1999.

AGARWAL, A., SALEH, R.A., BEDAIWY, M.A. Role of reactive oxygen species in the pathophysiology of human reproduction. Fertility and Sterility, v. 79, p. 829-843, 2003.

ALBERTINI, D.F., COMBElleS, C.M.H., BENECCHI, E., CARABATSOSMJ. Cellular basis for paracrine regulation of ovarian follicle development. Reproduction, v. 121, p. 647-653, 2001.

AMANAI, M., SHOJI, S., YOSHIDA, N., BRAHMAJOSYULA, M., PERRY, A. C. F. Injection of mammalian metaphase II oocytes with short interfering RNAs to dissect meiotic and early mitotic events. Biology of Reproduction, v. 75, p. 891-898, 2006.

AMLEH, A., DEAN, J. Mouse genetics provides insight into folliculogenesis, fertilization and early embryonic development. Human Reproduction Update, v. 8, n. 5, p. $395-403,2002$

ANCIOTO, K.L., VANTINI, R., GARCIA, L.M., MINGOTI, G.Z. Influência das células do cumulus e do meio de maturação in vitro de oócitos bovinos sobre a maturação nuclear e aquisição da competência do desenvolvimento embrionário. Acta Scientiae Veterinariae, v. 32, p. 118, 2004.

ANDERSON, E., LBERTINI, D.F. Gap junctions between the oocyte and companion follicle cells in the mammalian ovary. The Journal of Cell Biology, v. 71, n. 2, p. 680686, 1976. 
ANGUITA, B., JIMENEZ, MACEDO. A,R., IZQUIERDO, D., MOGAS, T., PARAMIO, M.T. Effect of oocyte diameter on meiotic competence, embryo development, p34 (cdc2) expression and MPF activity in prepuberal goat oocytes. Theriogenology, v. 67, p. 526-536, 2007.

ARMSTRONG, D.T., XIA, P., DE GANNES, G., TEKPETEY, F.R., KHAMSI, F. Differential effects of insulin-like growth factor-I and follicle-stimulating hormone on proliferation and differentiation of bovine cumulus cells and granulosa cells. Biology of Reproduction, v. 54, p. 331-338, 1996.

AUSTIN, C. R., SHORT, R. V. Germ cells and fertilization: Reproduction in mammals. 2. ed. Cambridge: New York, 1982. 177p.

BARBOSA, A.S., L.I.N, C.J. Silenciamento de genes com RNA interferência: Um novo instrumento para investigação da fisiologia e fisiopatologia do córtex adrenal. Arquivos Brasileiros de Endocrinologia e Metabologia, v.48, n. 5, p. 612-619, 2004.

BAULCOMBE, D. RNA silencing. Current Biology, v.12, n.3, p. R82-R84, 2002.

BEVERS, M.M., DIELEMAN, S.J., HURK, V.D.R., IZADYAR, F. Regulation and modulation of oocyte maturation in bovine. Theriogenology, v.47, p.13-22, 1997.

BLONDIN, P., COENEN, K., GUILBAULT, L.A., SIRARD, M.A. In vitro production of bovine embryos: developmental competence is acquired before maturation. Theriogenology, v. 47, n. 5, p. 1061-1075, 1997.

BODENSTEINER, K. J., CLAY, C. M., MOELLER, C. L., SAWYER, H. R. Molecular cloning of the ovine growth/differentiation factor-9 gene and expression of growth/differentiation factor-9 in ovine and bovine ovaries. Biology of Reproduction, v. 60, p. 381-386, 1999.

BRAW-TAL, R. The initiation of follicle growth: the oocyte or the somatic cells? Molecular and Cellular Endocrinology, v. 187, p. 11-18, 2002. 
CAIXETA, E. T., OliveIRA, A. C. B., BRITO, G. G., SAKIYAMA, N. S. Tipos de marcadores moleculares. In: BORÉM, A., CAIXETA, E. T. (Eds.). Marcadores moleculares. v.2, p.371-442, 2009.

CALDER, M.D., CAVENEY, A.N., SMITH, L.C., WATSON, A.J. Responsiveness of bovine cumulusoocyte-complexes (COC) to porcine and recombinant human FSH, and the effect of COC quality on gonadotropin receptor and Cx43 marker gene mRNAs during maturation in vitro. Reproductive Biology and Endocrinology, v. 11, p. 1-14, 2003.

CAMPBELl, B., DICKEY, J., BECKMAN, B., YOUNG, G., PIERCE, A., FUKADA, H., SWANSON, P. Previtellogenic oocyte growth in salmon: relationships among body growth, plasma insulin-like growth factor-1, estradiol-17b, follicle-stimulating hormone and expression of ovarian genes for insulin-like growth factors, steroidogenic-acute regulatory protein and receptors for gonadotropins, growth hormone and somatolactin. Biology of Reproduction, v. 75, p. 34-44, 2006

CARABATSOS, M. J., LEVIN, J., MATZUK, M. M., ALBERTINI, D. F. Characterization of oocyte and follicle development in growth differentiation factor-9deficient mice. Developmental Biology, v. 204, p. 373-384, 1998.

CATTANACH, B. M., IDDON, C. A., CHARLTON, H. M., CHIAPPA, S. A., FINK, G. Gonadotrophin-releasing hormone deficiency in a mutant mouse with hypogonadism. Nature, v. 269, p. 338-340, 1977.

CHA, K., HAN, S., CHUNG, H., CHOI, D., LIM, J., LEE, W., KO, J. J., YOON, T. K. Pregnancies and deliveries after in vitro maturation culture followed by in vitro fertilization and embryo transfer without stimulation in women with polycystic ovary syndrome. Fertility and Sterility, v. 73, p. 978-983, 2000.

CHAVES, R.N., A.B.G. DUARTE, M.H.T. MATOS, J.R. FIGUEIREDO. Sistemas de cultivo in vitro para o desenvolvimento de oócitos imaturos de mamíferos. Revista Brasileira de Reprodução. Animal, v.34, n.1, p.37-49, 2010. 
CHIAN, R.C., BUCKETT, W.M., ABDUL JALIL, A.K., SON, W.Y., SYLVESTRE, C., RAO, D., TAN, S.L. Natural-cycle in vitro fertilization combined with in vitro maturation of immature oocytes is a potential approach in infertility treatment. Fertility and Sterility, v. 82, n. 6, p 1675-1678, 2004.

CONTI, M., HSIEH, M., PARK, J.Y., SU, Y.Q. Role of the epidermal growth factor network in ovarian follicles. Molecular and Cellular Endocrinology, v. 20, p. 715-723, 2006.

CORBEAU, P. Interfering RNA and HIV: Reciprocal Interferences. PLoS Pathogens, v. 4, n. 9, e1000162, 2008.

COTICCHIO, G., SERENI, E., SERRAO, L., MAZZONE, S., IADAROLA, I., BORINI, A. What criteria for the definition of oocyte quality? New York Academy of Sciences, v. 1034, p. 132-144, 2004.

CROZET, N., AHMED-ALI, M., DUBOS, M.P. Developmental competence of goat oocytes from follicles of different size categories following maturation, fertilization and culture in vitro. Journal of reproduction and fertility, v. 103, n. 2, p. 293-298, 1995.

DALlAS, A., BALATSKAYA, S.V., KUO, T.C., ILVES, H., VlASSOV, A.V., KASPAR, R.L., KISICH, K.O., KAZAKOV, S.A., JOHNSTON, B.H. Hairpin ribozymeantisense RNA constructs can act as molecular Lassos. Nucleic Acids Research, v. 36, n. 21, p. 6752-6766, 2008.

DALLAS, A., VLASSOV, A.V. RNAI: a novel antisense technology and its therapeutic potential. Medical Science Monitor, v. 12, n. 4, p. RA67-74, 2006.

DASS, C. R. Lipoplez-mediated delivery of nucleic acids: factors affecting in vivo transfection. Journal of Molecular Medicine, v. 82, p. 579-591, 2004.

DERYNCK, R. Smad proteins and mammalian anatomy. Nature, v. 393, p. 737-239, 1998. 
DI PASQUALE, E., BECK-PECCOZ, P., PERSANI, L. Hypergonadotropic ovarian failure associated with an inherited mutation of human bone morphogenetic protein-15 (BMP15) gene. American Journal of Human Genetics, v. 75, p. 106-111, 2004.

DIAZ, F. J., WIGGLESWORTH, K., EPPIG, J. J. Oocytes are required for the preantral granulosa cell to cumulus cell transition in mice. Developmental Biology. v. 305, p. 300$311,2007$.

DIAZ, F.J., O'BRIEN, M.J., WIGGLESWORTH, K., EPPIG, J.J. The preantral granulosa cell to cumuluscell transition in the mouse ovary: development of competence to undergo expansion. Developmental Biology, v. 299, n. 1, p. 91-104 2006.

DONG, J., ALBERTINI, D. F., NISHIMORI, K., RAJENDRA KUMAR, T., LU, N., MATZUK, M. M. Growth differentiation factor- 9 is required during early ovarian folliculogenesis. Nature, v. 383, p. 531-535, 1996.

DRAGOVIC, R. A., RITTER, L. J., SCHUlZ, S. J., AMATO, F., THOMPSON, J. G., ARMSTRONG, D. T., GILCHRIST, R. B. Oocyte-secreted factor activation of SMAD 2/3 signaling enables initiation of mouse cumulus cell expansion. Biology of Reproduction, v. 76, p. 848-857, 2007.

DUBE, J. L., WANG, P., ELVIN, J., LYONS, K. M., CELESTE, A. J., MATZUK, M. M. The bone morphogenetic protein 15 gene is x-linked and expressed in oocytes. Molecular Endocrinology, v. 12, n. 12, p. 1809-1817, 1998.

ECKERY, D. C., WHALE, L. J., LAWRENCE, S. B., WYLDE, K. A., MCNATTY, K. P., JUENGEL, J. L. Expression of mRNA encoding Growth Differentiation Factor 9 and bone morphogenetic protein 15 during follicular formation and growth in a marsupial, the brushtail possum (Trichosurus vulpecula). Molecular and Cellular Endocrinology, v. 192, p. 115-126, 2002.

ELVIN, J. A., ClARK, A. T., WANG, P., WOLFMAN, N. M., MATZUK, M. M. Paracrine actions of growth differentiation factor-9 in the mammalian ovary. Molecular Endocrinology, v. 13, n. 6, p. 1035-1048, 1999. 
ELVIN, J. A., YAN, C., MATZUK, M. M. Growth differentiation factor-9 stimulates progesterone synthesis in granulose cells via prostaglandin E2/EP2 receptor pathway. Proceedings of the National Academy of Sciences, v. 97, n. 18, p. 10288-10293, 2000.

EMANUELLI, I. P. et al. Líquido folicular na inibição da maturação nuclear de oócitos bovinos. Arq. Fac. Vet. UFRGS, v. 28, n. 1, p. 246, 2000.

EPPIG, J. J., CHESNEL, F., HIRAO, Y., O’BRIEN, M. J., PENDOLA, F. L., WATANABE, S., WIGGLESWORTH, K. Oocyte control of granulosa cell development: how and why. Human Reproduction, v. 12, p. 127-132, 1997.

EPPIG, J.J. Oocyte control of ovarian follicular development and function in mammals. Reproduction, v. 122, n. 6, p. 829-838, 2001

EPPIG, J.J., SCHROEDER, A.C. Capacity of mouse oocytes from preantral follicles to undergo embryogenesis and development to live young after growth,maturation and fertilization in vitro. Biology of Reproduction, v.41, p.268-276, 1989.

EPPIG, J.J., SCHULTZ, R.M., O’BRIEN, M., CHESNEL, F. Relationship between the developmental programs controlling nuclear and cytoplasmic maturation of mouse oocytes. Developmental Biology, v. 164, p. 1-9, 1994.

ERICKSON, G. F., SHIMASAKI, S. The spatiotemporal expression pattern of the bone morphogenetic protein family in rat ovary cell types during the estrous cycle. Reproductive Biology and Endocrinology, v. 11, p. 9, 2003

ERICKSON, G.F., MAGOFFIN, D.A., DYER, C.A. The ovarian androgen producing cells: a review of structure-function relations. Endocrine Reviews, v. 6, p. 371-379, 1995.

EYESTONE, W., R. AX. A review of ovarian follicular cysts in cows, with comparison to the condition in cows, women, rats and rabbits. Theriogenology, v. 22, p. 109-125, 1984. 
FAIR T, HYTTEL P, GREVE T. Bovine oocyte diameter in relation to maturational competence and transcriptional activity. Molecular Reproduction and Development, v. 42, p. 437-442, 1995.

FAIR, T. Follicular oocyte growth and acquisition of developmental competence. Animal Reproduction Science, v. 78, p. 203-216, 2003.

FATEHI, A. N., VAN DEN HURK, R., COLENBRANDER, B., DAEMEN, A. J. J. M., VAN TOL, H. T. A., MONTEIRO, R. M., ROELEN, B. A. J., BEVERS, M. M. Expression of bone morphogenetic protein2 (BMP2), BMP4 and BMP receptors in the bovine ovary but absence of effects of BMP2 and BMP4 during IVM on bovine oocyte nuclear maturation and subsequent embryo development. Theriogenology, v. 63, p. 872$889,2005$.

Feuerstein, P., Cadoret, V., Dalbies-Tran, R., Guerif, F., Bidault, R., and Royere, D. Gene expression in human cumulus cells: one approach to oocyte competence. Human Reproduction, v. 22, n. 12, p. 3069-3077, 2007.

FEUERSTEIN, P., CADORET, V., DALBIES-TRAN, R., GUÉRIF, F., ROYÈRE, D. Oocyte-cumulus dialog, Gynecologie Obstetrique e Fertilite, v. 34, n. 9, p. 793-800, 2006.

Figueiredo, J. R., CELESTINO, J. J. H., RODRIGUES, A. P. R., SilVA, J. R. V. Importância da biotécnica de MOIFOPA para o estudo da foliculogênese e produção in vitro de embriões em larga escala. Revista Brasileira de Reprodução Animal, v. 31, n. 2, p. 143-152, 2007.

FIRE, A., XU, S., MONTGOMERY, M.K., KOSTAS, S.A., DRIVER, S.E.,MELlO, C.C. Potent and specific genetic interference by double stranded RNA in Caenorhabditis elegans, Nature, v. 391, n. 6669, p. 806-811, 1998.

FISSORE, R.A., KUROKAWA, M., KNOTT, J., ZHANG, M., SMYTH, J. Mechanisms underlying oocyte activation and postovulatory ageing. Reproduction, v.124, p.745-754, 2002. 
FORTUNE, J.E. Ovarian follicular growth and development in mammals. Biology of Reproduction, v.50, p. 225-232, 1994.

FRANZEN, P., ten DIJKE, P., ICHIJO, H., YAMASHITA, H., SCHULZ, P., HELDIN, C. H., MIYAZONO, K. Cloning of a TGF- $\beta$ type I receptor that forms a heteromeric complex with the TGF- $\beta$ type II receptor. Cell, v. 75, p. 681-692, 1993.

FUKUI, Y., ONO, H. Effects of sera, hormones and granulose cells added to culture medium for in vitro maturation, fertilization, cleavage and development of bovine oocytes. Journal of Reproduction and Fertility, v.86, p.501-506, 1989.

FULOP, C., SZANTO, S., MUKHOPADHYAY, D., BARDOS, T., KAMATH, R. V., RUGG, M. S., DAY, A. J., SALUSTRI, A., HASCALL, V. C., GLANT, T. T., MIKECZ, K. Impaired cumulus mucification and female sterility in tumor necrosis factor-induced protein-6 deficient mice. Development, v. 130, p. 2253-2261, 2003.

GAllowAy, S. M., MCNATTY, K. P., CAMBRIDGE, L. M., LAITINEN, M. P. E., JUENGEL, J. L., JORIKANTA, T. S., MCLAREN, R. J., LUIRO, K., DODDS, K. G., MONTGOMERY, G. W., BEATTIE, A. E., DAVIS, G. H., RITVOS, O. Mutations in an oocyte-derived growth factor gene (BMP15) cause increased ovulation rate and infertility in a dosage-sensitive manner. Nature Genetics, v. 25, p. 279-283, 2000.

GANDOLFI, F., BREVINI, T.A., CILLO, F., ANTONINI, S. Cellular and molecular mechanisms regulating oocyte quality and the relevance for farm animal reproductive efficiency. Revue Scientifique et Technique, v. 24, p. 413-423, 2005.

GILCHRIST, R. B., RITTER, L. J., ARMSTRONG, D. T. Oocyte-somatic cell interactions during follicle development in mammals. Animal Reproduction Science, v. 82, p. 431-446, 2004.

GILCHRIST, R. B., RITTER, L. J., MYLLYMAA, S., KAIVO-OJA, N., DRAGOVIC, R. A., HICKEY, T. E., RITVOS, O., MOTTERSHEAD, D. G. Molecular basis of oocyte-paracrine signaling that promotes granulose cell proliferation. Journal of Cell Science, v. 119, p. 3811-3821, 2006. 
GILCHRIST, R.B., LANE, M., THOMPSON, J.G. Oocyte-secreted factors: regulators of cumulus cell unction and oocyte quality. Human Reproduction Update, v.14, n.2, p. 159-177, 2008.

GILCHRIST, R.B., THOMPSON, J.G. Oocyte maturation: emerging concepts and technologies to improve developmental potential in vitro. Theriogenology, v. 67, p. 6-15, 2007.

GILLOTT, D. J., ELDIB, A., IAMMARRONE, E., LEUNG, D. Y., THORNHILL, A. R., GRUDZINSKAS, J. G. Glycolytic enzyme expression in human granulosa cells. Fertility and Sterility, v. 90, p. 1405-1410, 2008.

GONG, J.G., CAMPBELL, B.K., BRAMLEY, T.A., GUTIERREZ, C.G., PETERS, A.R., WEBB, R. Suppression in the secretion of follicle-stimulating hormone and luteinizing hormone, and ovarian follicle development in heifers continuously infused with a gonadotropin-releasing hormone agonist. Biology of Reproduction, v. 55, p. 6874, 1996.

GRABAREK, J.B., PLUSA, B., GLOVER, D.M., ZERNICKA-GOETZ, M. Efficient delivery of dsRNA into zona-enclosed mouse oocytes and preimplantation embryos by electroporation. Genesis, v. 32, p. 269-276, 2002.

GUÉRIPEL, X., BRUN, V., GOUGEON, A. Oocyte bone morphogenetic protein 15, but not growth differentiation factor 9, is increased during gonadotropin-induced follicular development in the immature mouse and is associated with cumulus oophorus expansion. Biology of Reproduction, v.75, p. 836-843, 2006.

GUI, L. M., JOYCE, I. M. RNA Interference evidence that Growth Differentiation Factor-9 mediates oocyte regulation of cumulus expansion in mice. Biology of Reproduction, v. 72, p. 195-199, 2005.

HAFEZ, B., HAFEZ, E. S. E. Reprodução Animal. Ed. Manole: Barueri, 2004, 530p.

HAGHIGHAT, N., VAN WINKLE, L.J. Developmental change in follicular cellenhanced amino acid uptake into mouse oocytes that depends on intact gap junctions and transport system Gly. Journal of Experimental Zoology, v. 253, p. 71-82, 1990. 
HAMEL, M., DUFORT, I., ROBERT, C., GRAVEL, C., LEVEILLE, M.C., LEADER, A., SIRARD, M.A. Identification of differentially expressed markers in human follicular cells associated with competent oocytes. Human Reproduction, v. 23, p. 1118-1127, 2008.

HAMMOND, S.M., CAUDY, A.A., HANNON, G.J. Post-transcriptional gene silencing by double-stranded RNA. Nature Reviews Genetics, v. 2, p. 110-119, 2001.

HANRAHAN, J. P., GREGAN, S. M., MULSANT, P., MUlLEN, M., DAVIS, G. H., POWELL R., GALLOWAY, S. M. Mutations in the genes for oocyte-derived growth factors GDF9 and BMP15 are associated with both increased ovulation rate and sterility in Cambridge and Belclare sheep (ovis aries). Biology of Reproduction, v. 70, p. 900909, 2004.

HARDY, K., WRIGHT, C.S., FRANKS, S., WINSTON, R.M.L. In vitro maturation of oocytes. British Medical Bulletin, v.56, p.588-602, 2000.

HAYASHI, M., MCGEE, E. A., MIN, G., KLEIN, C., ROSE, U. M., VAN DUIN, M., HSUEH, A. J. W. Recombinant growth differentiation factor-9 (GDF-9) enhances growth and differentiation of cultured early ovarian follicles. Endocrinology, v. 140, n. 3, p. 1236-1244, 1999.

HAZELEGER, W.C., JANSE, J.D., KOENRAAD, P.M., BEUMER, R.R.,ROMBOUTS, F.M. AND ABEE, T. Temperature-depen-dent membrane fatty acid and cell physiology changes incoccoid forms of Campylobacter jejuni. Applied and Environmental Microbiology, v. 61, p. 2713-2719, 1995.

HELDIN, C. H., MIYAZONO, K., ten DIJKE, P. TGF- $\beta$ signaling from cell membrane to nucleus through SMAD proteins. Nature, v. 390, p. 465-471, 1997.

HENDRIKSEN, P.J., VOS, P.L, STEENWEG, W.N, BEVERS, M.M., DIELEMAN, S.J. Bovine follicular development and its effect on the in vitro competence of oocytes. Theriogenology, v.53: 11-20, 2000.

HICKEY, T. E., MARROCCO, D. L, AMATO, F., RITTER, J. L., NORMAN, R. J., GILCHRIST, R. B., ARMSTRONG, D. T. Androgens augment the mitogenic effects of 
oocyte-secreted factors and growth differentiation factor 9 on porcine granulosa cells. Biology of Reproduction, v. 73, p. 825-832, 2005.

HICKEY, T. E., MARROCCO, D. L., GILCHRIST, R. B., NORMAN, R. J., ARMSTRONG, D. T. Interactions between androgen and growth factors in granulosa cell subtypes of porcine antral follicles. Biology of Reproduction, v. 71, p. 45-52, 2004.

HIRSHFIELD, A. N. Development of follicles in the mammalian ovary. International Review of Cytology, v. 124, p. 43-101, 1991.

HOOD, E. RNAi: What's all the noise about gene silencing? Environmental Health Perspectives, v. 112, n. 4, p. A224-A229.

HSUEH, A. J. W., ADASHI, E. Y., JONES, P. B. C., WELSH, T. H. Hormonal regulation of differentiation of cultured ovarian granulosa cells. Endocrinology Reviews, v. 5, p. 76-127, 1984.

HUNTER, M.G. Oocyte maturation and ovum quality in pigs. Reviews of Reproduction, v.5, p.122-130, 2000.

HUSSEIN, T. S., FROILAND, T. S., AMATO, F., THOMPSON, J. G., GILCHRIST, R. B. Oocytes prevent cumulus cell apoptosis by maintaining a morphogenic paracrine gradient of bone morphogenetic proteins. Journal of Cell Science, v. 118, n. 22, p. 5257 $5268,2005$.

HUSSEIN, T. S., THOMPSON, J. G., GILCHRIST, R. B. Oocyte-secreted factors enhance oocyte developmental competence. Developmental Biology, v. 296, p. 514-521, 2006.

HUTT, K. J., MCLAUGHLIN, E. A., HOLlAND, M. K. Kit ligand and c-Kit have diverse roles during mammalian oogenesis and folliculogenesis. Molecular Human Reproduction, v. 12, p. 61-69, 2006.

HUTT, K.J., ALBERTINI, D.F. An oocentric view of folliculogenesis and embryogenesis. Reproductive Biomedicine Online, v.14, p.758-764, 2007. 
IRELAND, J.J., ROCHE, J.F. Growth and differentiaton of large antral follicles after spontaneous luteolysis in heifers: changes in concentration of hormones in folicular fluid and specific binding of gonadotropins to follicles. Journal Animal Science, v.57, n.1, p.157-67, 1983.

IZADYAR, F., HAGE, W.J., COLENBRANDER, B., BEVERS, M.M. The promotory effect of growth hormone on the developmental competence of in vitromatured bovine oocytes is due to improved cytoplasmic maturation. Molecular Reproduction and Development, v. 49, n. 4, p. 444-53, 1998.

JAATINEN, R., ROSEN, V., TUURI, T., RITVOS, O. Identification of ovarian granulosa cells as a novel site of expression for bone morphogenetic protein-3 (BMP3/osteogenin) and regulation of BMP-3 messenger ribonucleic acids by chorionic gonadotropin in cultured human granulosa-luteal cells. Journal of Clinical Endocrinology and Metabolism, v. 81, p. 3877-3882, 1996.

JOYCE, I.M., CLARK, A.T., PENDOLA, F.L., EPPIG, J.J. Comparison of recombinant growth factor-9 and oocyte regulation of Kit ligand messenger ribonucleic acid expression in mouse ovarian follicles. Biology of Reproduction, v. 63, p. 1669-1675, 2000 .

JOYCE, I.M., PENDOLA, F.L., WIGGLESWORTH, K., EPPIG, J.J. Oocyte regulation of kit ligand expression in mouse ovarian follicles. Developmental Biology, v. 214, p. 342-353, 1999.

JUENGEL, J. L., MCNATTY, K. P. The role of proteins of the transforming growth factor- $\beta$ superfamily in the intraovarian regulation of follicular development. Human Reproduction Update, v. 11, n. 2, p. 144-161, 2005.

JUENGEL, J.L., BODENSTEINER, K.J., HEATH, D.A., HUDSON, N.L., MOELLER, C. ., SMITH, P., GALLOWAY, S.M., DAVIS, G.H., SAWYER, H.R., MCNATTY, K.P. Physiology of GDF9 and BMP15 signaling molecules. Animal Reproduction Science, v. 82-83, p. 447-460, 2004. 
JUENGEL, J.L., HUDSON, N.L., HEATH, D.A., SMITH, P., READER, K.L., LAWRENCE, S.B., O’CONNELL, A.R., LAITINEN, M.P.E., CRANFIELD, M., GROOME, N.P., RITVOS, O., MCNATTY, K.P. Growth Differentiation Factor 9 and Bone Morphogenetic Protein 15 are essential for ovarian follicular development in sheep. Biology of Reproduction, v. 67, p. 1777-1789, 2002.

KAIVO-OJA, N., BONDESTAM, J., KAMARAINEN, M., KOSKIMIES, J., VITT, U., CRANFIELD, M., VUOJOLAINEN, K., KALliO, J. P., OLKKONEN, V. M., HAYASHI, M., MOUSTAKAS, A., GROOME, N. P., ten DIJKE, P., HSUEH, A. J., RITVOS, O. Growth Differentiation Factor-9 induces Smad2 activation and inhibin B production in cultured human granulosa-luteal cells. Journal of Clinical Endocrinology e Metabolism, v.88, p. 755-762, 2003.

KIM, B.K., ANOWER JABED, M., KANG, S.R., KIM, D., CHANG-HEE HAN, HUH M.K., KAMAL, T. Effects of spermatozoa during in vitro meiosis progression in the porcine germinal vesicle oocytes. Animal Reproduction Science, v.104, p.83-92, 2008.

KNIGHT, P.G., GLISTER, C. Potential local regulatory functions of inhibins, activins and follistatin in the ovary. Reproduction, v. 121, p. 503-512, 2001.

KNIGHT, P.G., GLISTER, C. TGF-beta superfamily members and ovarian follicle development. Reproduction, v. 132, p. 191-206, 2006.

KOBAYASHI, S., SAKATANI, M., KOBAYASHI, S., OKUDA, K., TAKAHASHI, M. Gene silencing of cyclooxygenase- 2 mRNA by RNA interference in bovine cumulusgranulosa cells. Journal of Reproduction and Development, v.53, p.1305-1311, 2007.

KOLE, R., A.R. KRAINER, S. ALTMAN. RNA therapeutics: beyond RNA interference and antisense oligonucleotides. Nature Reviews Drug Discovery, v. 11, p. 125-140, 2012 .

KUMAR, T. R., WANG, Y., LU, N., MATZUK, M. M. Follicle stimulating hormone is required for ovarian follicle maturation but not male fertility. Nature Genetics, v.15, p.201-204, 1997. 
KURRECK, J. Antisense technologies: Improvement through novel chemical modifications. European Journal of Biochemistry, v. 270, p. 1628-1644, 2003.

LAEMMLY, U.K. Cleavage of structural proteins during the assembly of the head of bacteriophage T. Nature, v. 227, p. 680-685, 1970.

LAGNA, G., HATA, A., HEMMATI-BRIVANLOU, A., MASSAGUE, J. Partnership between DPC4 and SMAD proteins in TGF- $\beta$ signaling pathways. Nature, v. 383, p. 832-836, 1996.

LAITINEN, M., VUOJOLAINEN, K., JAATINEN, R., KETOLA, I., AALTONEN, J., LEHTONEN, E., HEIKINHEIMO, M., RITVOS, O. A novel Growth Differentiation Factor-9 (GDF-9) related factor is co-expressed with GDF-9 in mouse oocytes during folliculogenesis. Mechanisms of development, v. 78, p. 135-140, 1998.

LAN, Z. J., GU, P., XU, X., JACKSON, K., DEMAYO, F. J., O’MALlEY, B. W., COONEY, A. J. GCNF-dependent repression of BMP-15 and GDF-9 mediates gamete regulation of female fertility. The Embo Journal, v. 22, n. 16, p. 1-12, 2003.

LANUZA, G. M., FISCHMAN, M. L., BARANAO, J. L. Growth promoting activity of oocytes on granulosa cells is decreased upon meiotic maturation. Developmental Biology, v. 197, p. 129-139, 1998.

LATHAM, K.E., BAUTISTA, D.M., HIRAO, Y., O’BRIEN, M.J., EPPIG, J.J. Comparison of protein synthesis patterns in mouse cumuluscells and mural granulosa cells: effects of follicle-stimulating hormone and insulin of granulosa cell differentiation in vitro. Biology of Reproduction, 61, 482- 492, 1999.

LEE, J., MIYANO, T., MOOR, R.M. Spindle formation and dynamics of gamma-tubulin and nuclear mitotic apparatus protein distribution during meiosis in pig and mouse oocytes. Biology of Reproduction, v. 62, p. 1184-1192, 2000.

LI, H. K., KUO, T. Y., YANG, H. S., CHEN, L. R., LI, S. S. L., HUANG, H. W. Differential gene expression of bone morphogenetic protein 15 and growth differentiation factor 9 during in vitro maturation of porcine oocytes and early embryos. Animal Reproduction Science, v.103, p.312-322, 2008a. 
LI, Q., MCKENZIE, L. J., MATZUK, M. M. Revisiting oocyte-somatic cell interactions: in search of novel intrafollicular predictors and regulators of oocyte developmental competence. Molecular Human Reproduction, v. 14, n. 12, p. 673-678, 2008 b.

LI, R., NORMAN, R. J., ARMSTRONG, D. T., GILCHRIST, R. B. Oocyte-secreted factor(s) determine functional differences between bovine mural granulosa cells and cumulus cells. Biology of Reproduction, v. 63, p. 839-845, 2000.

LIMA, R.S. O papel do fator de crescimento semelhante à insulina-I sobre os efeitos deletérios do choque térmico em oócitos bovinos no estádio de vesícula germinativa. 2012. 110f. Tese (Doutorado em Medicina Veterinária) Faculdade de Medicina Veterinária e Zootecnia. Universidade Estadual Paulista, Botucatu, 2012.

LIVAK, K.J.; SCHMITTGEN, T.D. Analysis of relative gene expression data using realtime quantitative PCR and the 2(-Delta Delta C(T)) method. Methods, v.25, p.402-408, 2001.

LONERGAN, P., MONAGHAN, P., RIZOS, D., BOLAND, M.P.,GORDON, I. Effect of follicle size on bovine oocyte quality and developmental competence following maturation, fertilization, and culture in vitro. Molecular Reproduction and Development, v.37, 48-53, 1994.

LONERGAN, P., RIZOS, D., GUTIÉRREZ-ADÁN, A., FAIR, T., BOLAND, M.P. Effect of culture environment on embryo quality and gene expression - experience from animal studies. Reproductive BioMedicine Online, v.7, p.97-103, 2003.

LUCY, M.C., THATCHER, W.W., SAVIO, J.D., DANET-DESNOYERS, G., MOSER, M.T.,BADINGA, L., SIMMEN, F.A., COLLIER, R.J. Effect of bovine somatotropin on ovarian follicles, copora lutea, and embryos during early pregnancy in cattle. Journal of Animal Science, v. 70, 271, 1992.

MASSAGUÉ, J. 1998. TGF $\beta$ signal transduction. Annual Review of Biochemistry. 67: 753-791.

MASSAGUE, J., ATTISANO, L. AND WRANA, J. L. The TGF- $\beta$ family and its composite receptors. Trends in Cell Biology, v. 4, p. 172-178, 1994. 
MATZUK, M.M., BURNS, K.H., VIVEIROS, M.M., EPPIG, J.J. Intercellular communication in the mammalian ovary: oocytes carry the conversation. Science, v. 296, p. 2178-2180, 2002.

MAZERBOURG, S., BOULEY, D.M., SUDO, S., KLEIN, C.A., ZHANG, J.V., KAWAMURA, K., GOODRICH, L.V., RAYBURN, H., TESSIER-LAVIGN, E.M., HSUEH, A.J. Leucine-rich repeat-containing, G protein-coupled receptor 4 null mice exhibit intrauterine growth retardation associated with embryonic and perinatal lethality. Molecular Endocrinology, v. 18, p. 2241-2254, 2004a.

MAZERBOURG, S., HSUEH, A.J.W. Genomic analyses facilitate identification of receptors and signalling pathways for growth differentiation factor 9 and related orphan bone morphogenetic protein/growth differentiation factor ligands. Human Reproduction Update, v. 12, p. 373-383, 2006.

MAZERBOURG, S., KLEIN, C., ROH, J., KAIVO-OJA, N., MOTTERSHEAD, D. G.,KORCHYNSKI, O., RITVOS,O. Growth differentiation factor-9 signaling is mediated by the type I receptor, activin receptor-like kinase 5. Molecular Endocrinology, v.18, p.653-665, 2004b.

McGEE, E. A., HSUEH, A. J. Initial and cyclic recruitment of ovarian follicles. Endocrinology Reviews, v. 21, p. 200-214, 2000.

McGRATH, S.A., ESQUELA, A.F., LEE, S.J. Oocyte-specific expression of growth/differentiation factor-9. Molecular Endocrinology, v. 9, p. 131-136, 1995.

McNATTY, K. P., JUENGEL, J. L., WILSON, T., GALLOWAY, S. M., DAVIS, G. H., HUDSON, N. L., MOELlER, C. L., CRANFIELD, M., READER, K. L., LAITINEN, M. P., GROOME, N. P., SAWYER, H. R., RITVOS, O. Oocyte derived growth factors and ovulation rate in sheep. Reproduction, v. 61, p. 339-351, 2003.

McNATTY, K. P., MOORE, L. G., HUDSON, N. L., QUIRKE, L. D., LAWRENCE, S. B., READER, K., HANRAHAN, J. P., SMITH, P., GROOME, N. P., LAITINEN, M., RITVOS, O., JUENGEL, J. L. The oocyte and its role in regulating ovulation rate: a new paradigm in reproductive biology. Reproduction Review, v. 128, p. 379-386, 2004. 
McNATTY, K.P., JUENGEL, J.L., READER, K.L., LUN, S., MYLLYMAA, S., LAWRENCE, S.B., WESTERN, A., MEERASAHIB, M.F., MOTTERSHEAD, D.G., GROOME, N.P., RITVOS, O., LAITINEN, M. P. E. Bone morphogenetic protein 15 and growth differentiation factor 9 co-operate to regulate granulosa cell function. Reproduction, v. 129, p. 473-480, 2005 b.

McNATTY, K.P., SMITH, P., MOORE, L.G., READER, K., LUN, S., HANRAHAN, J. P., GROOME, N. P., LAITINEN, M., RITVOS, O., JUENGEL, J. L. Oocyte expressed genes affecting ovulation rate. Molecular and Cellular Endocrinology, v. 234, p. 57-66, 2005a.

McPHERRON, A.C., LEE, S.J. GDF-3 and GDF-9: two new members of the transforming growth factor- $\beta$ superfamily containing a novel pattern of cysteines. The Journal of Biological Chemistry, v. 268, p. 3444-3449, 1993.

MOCELlin, S., PROVENZANO, M., ROSSI, C.R., PILATI, P.L., NITTI, D., LISE, M. DNA array-based gene profiling: from surgical specimen to the molecular portrait of cancer. Annals of Surgery, v. 241, p. 16-26, 2005.

MOENTER, S.M., BRAND, R.M., MIDGLEY, A.R., KARSCH, F.J. Dynamics of gonadotropin-releasing hormone release during a pulse. Endocrinology, v. 130, p. 503$510,1992$.

MOORE, R. K., OTSUKA, F., SHIMASAKI, S. Molecular basis of Bone Morphogenetic Protein-15 signaling in granulosa cells. The Journal of Biological Chemistry, v. 278, n. 1, p.304-310, 2003.

MOORE, R.K., SHIMASAKI, S. Molecular biology and physiological role of the oocyte factor, BMP-15. Molecular and Cellular Endocrinology, v. 234, p. 67-73, 2005.

NGANVONGPANIT, K., MÜlLER, H., RINGS, F., HOELKER, M., JENNEN, D., THOLEN, E., HAVLICEK, V., BESENFELDER, U., SCHELLANDER, K., TESFAYE, D. Selective degradation of maternal and embryonic transcripts in in vitro produced bovine oocytes and embryos using sequence specific double-stranded RNA. Reproduction, v.131, p.861-874, 2006. 
NISHIMURA, R., KATO, Y., CHEN, D., HARRIS, S.E., MUNDY, G.R., YONEDA, T.Smad5 and DPC4 are key molecules in mediating BMP-2- induced osteoblastic differentiation of the pluripotent mesenchymal precursor cell line C2C12. The Journal of Biological Chemistry, v. 273, p. 1872-1879, 1998.

NOGUEIRA, D., RON-EL, R., FRIEDLER, S., SCHACHTER, M., RAZIEL, A., CORTVRINDT, R., SMITZ, J. Meiotic arrest in vitro by phosphodiesterase 3-inhibitor enhances maturation capacity of human oocytes and allows subsequent embryonic development. Biology of Reproduction, v. 74, p. 177-184, 2006.

OLIVEIRA, R. R., CARVALHO, D. M., LISAUSKAS, S., MELO, E., VIANNA, G. R., DODE, M. A. N., RUMPF, R., ARAGÃO, F. J. L., RECH, E. L. Effectiveness os lipossomes to transfect livestock fibroblasts. Genetics and Molecular Research, v. 4, p. 185-196, 2005.

ORISAKA, M., ORISAKA, S., JIANG, J. Y., CRAIG, J., WANG, Y., KOTSUJI, F., TSANG, B. K. Growth Differentiation Factor 9 is antiapoptotic during follicular development from preantral to early antral stage. Molecular Endocrinology, v. 20, n. 10, p. 2456-2468, 2006.

OTSUKA, S., ADAMSON, C., SANKAR, V., GIBBS, K.M., KANE-GOLDSMITH, N., AYER, J.J., BABIARZ, J., KALINSKI, H., ASHUSH, H., ALPERT, E., LAHAV, R., FEINSTEIN, E., GRUMET, M. Delayed intrathecal delivery of RhoA siRNA to the contused spinal cord inhibits allodynia, preserves white matter and increases serotonergic fiber growth. Journal Neurotrauma, v.28, 1063-76, 2011.

OTSUKA, F., YAO, Z., LEE, T., YAMAMOTO, S., ERICKSON, G. F., SHIMASAKI, S. Bone morphogenetic protein-15: Identification of target cells and biological functions. The Journal of Biological Chemistry, v. 275, n. 50, p. 39523-39528, 2000.

PANGAS, S.A., JORGEZ, C.J., MATZUK, M.M. Growth differentiation factor 9 regulates expression of the bone morphogenetic protein antagonist gremLin. Journal of Biological Chemistry, v.279, p.32281-32286, 2004. 
PANGAS, S. A., MATZUK, M. M. The art and artifact of GDF9 activity: cumulus expansion and the cumulus expansion-enabling factor. Biology of Reproduction, v. 73, p. 582-585, 2005.

PARADIS, F., VIGNEAULT, C., ROBERT, C., SIRARD, M.A. RNA interference as a tool to study gene function in bovine oocytes. Molecular Reproduction and Development, v. 70, p. 111-121, 2005

PARROT, J.A., SKINNER, M.K. Kit ligand actions on ovarian stromal cells: effects on theca cell recruitment and steroid production. Molecular Reproduction and Development, v.55, p.55-64, 2000.

PATIL, S. D., RHODES, D. G., BURGESS, D. J. Biophysical characterization of anionic lipoplexes. Biochimica et Biophysica Acta, v. 1171, p. 1-11, 2005.

PAULINI, F. Expressão do Growth and Differentiation Factor9 (GDF9) e Bone Morphogenetic Protein 15 (BMP15) in vitro e seu efeito no processo de luteinização das células da granulosa bovinas. 2010, 101p. Dissertação (Mestrado em Medicina Veterinária) - Faculdade de Agronomia e Medicina Veterinária, Universidade de Brasília, Brasília, 2010.

PEDERSEN, T., PETERS, H. Proposal for a classification of oocytes and follicles in the mouse ovary. Journal of Reproduction and Fertility, v. 17, p. 555-557, 1968.

PEDERSEN, T., PETERS, H. Proposal for a classification of oocytes and follicles in the mouse ovary. Journal of reproduction and fertility, v. 17, n. 3, p. 555-557, 1968.

PENG, X. R., HSUEH, A. J. W., LAPOLT, P. S., BJERSING, L., NY, T. Localization of luteinizing hormone receptor messenger ribonucleic acid expression in ovarian cell types during follicle development and ovulation. Endocrinology, v. 129, p. 3200-3207, 1991.

PETERS, H. The development of the mouse ovary from birth to maturity. Acta endocrinologica, v. 62, p. 98-116, 1969. 
RICHARD, F. J., SIRARD, M. A. Effects of follicular cells on oocyte maturation. II:Theca cell inhibition of bovine oocyte maturation in vitro. Biology of Reproduction, v.54, p. 22-28, 1996.

RICHARDS, J.S. Hormonal control of gene expression in the ovary. Endocrinology Reviews, v. 15, p. 725-751, 1994.

RIZOS, D., GUTIERREZ-ADAN, A., PEREZ-GARNELO, S. et al. Bovine embryo culture in the presence or absence of serum: implications for blastocyst development, cryotolerance, and messenger RNA expression. Biology of Reproduction, v.68, p.236243, 2003.

ROH, J. S., BONDESTAM, J., MAZERBOURG, S., KAIVO-OJA, N., GROOME, N., RITVOS, O., HSUEH, A. J. Growth differentiation factor-9 stimulates inhibin production and activates smad2 in cultured rat granulosa cells. Endocrinology, v. 144, p. 172-178, 2003.

ROMOREN, K., FJELD, X. T. L., POLEO, A. B. S., SMISTAD, G., THU, B. J. EVENSEN, O. Trasnfections efficiency and cytotoxicity of cationic liposomes in primary cultures of rainbow trout (Oncorhynchus mukiss) gill cells. Biochimica et Biophysica Acta, v. 1717, p. 50-57, 2005.

ROTH, Z., HANSEN, P.J. Disruption of nuclear maturation and rearrangement of cytoskeletal elements in bovine oocytes exposed to heat shock during maturation. Reproduction, v. 129, n. 2, 235-244, 2005.

ROUILliER, P., MATTON, P., SIRARD, M.A., GUILBAULT, L.A. Folliclestimulating hormone-induced estradiol and progesterone production by bovine antral and mural granulosa cells cultured in vitro in a completely defined medium. Journal of Animal Science, v. 74, n. 12, p. 3012-3019, 1996.

RÜSSE, I. Oogenesis in cattle and sheep. Bibliography Anatomical, v. 24, p. 77-92, 1983. 
SAUMANDE, J. Culture of bovine granulosa cells in a chemically defined serum-free medium: the effect of insulin and fibronectin on the response to FSH. The Journal of Steroid Biochemistry and Molecular Biology, v. 38, n. 2, p. 189-196, 1991.

SAWYER, H.R., SMITH, P., HEATH, D.A., JUENGEL, J.L., WAKEFIELD, S.J., MCNATTY, K.P. Formation of ovarian follicles during fetal development in sheep. Biology of Reproduction, v. 66, p. 1134-1150, 2002.

SCHOENWOLF, G.C., BLEYL, S.B., BRAUER, P.R., FRANCIS-WEST, P.H. Larsen's Human Embryology, 4th edition. Philadelphia: Churchill Livingstone Elsevier, 2008.

SHARMA, G. T., A. C. MAJUMDAR AND S. W. BONDE. Chronology of maturational events in goat oocytes cultured in vitro. Small Ruminant Research, v. 22, p. 25-30. 1996.

SHIMASAKI, S., MOORE, R.K., ERICKSON, G.F., OTSUKA, F. The role of bone morphogenetic proteins in ovarian function. Reproduction, v. 61, p. 323-337, 2003.

SHIMASAKI, S., MOORE, R. K., OTSUKA, G., ERICKSON, G. F. The bone morphogenetic protein system in mammalian reproduction. Endocrine Reviews, v. 251, n. 1, p. 72-101, 2004.

SILVA, J.R., VAN DEN HURK, R., VAN TOL, H.T., ROELEN, B.A., FIGUEIREDO, J.R. Expression of growth differentiation factor 9 (GDF9), bone morphogenetic protein 15 (BMP15), and BMP receptors in the ovaries of goats. Molecular Reproduction and Development, v. 70, p. 11-19, 2005.

SILVA, J.R.V., VAN DEN HURK, R., MATOS, M.H.T., SANTOS, R.R., PESSOA, C., MORAES, M.O., FIGUEIREDO, J.R. Influences of FSH and EGF on primordial follicles during in vitro culture of caprine ovarian cortical tissue. Theriogenology, v.61, p.16911704, 2004.

SIMON, A. M., GOODENOUGH, D. A., LI, E., PAUL, D. L. Female infertility in mice lacking connexin 37. Nature, v. 385, p. 525-529, 1997.

SIRARD, M. Resumption of meiosis: mechanism involved in meiotic progression and its relation with developmental competence. Theriogenology, v.55, p.1241-1254, 2001. 
SIRARD, M.A., PARRISH, J.J., WARE, C.B., LEIBFRIED-RUTLEDGE, M.L.,FIRST, N.L. The culture of bovine oocytes to obtain developmentally competent embryos. Biology of Reproduction, v. 39, n. 3, p. 546-552, 1988.

SKINNER, M.K. Regulation of primordial follicle assembly and development. Human Reproduction Update, v. 11, p. 461-471, 2005.

SMITZ, J.E.J., NOGUEIRA, D., VANHOUTTE MATOS, D.G., CORTVRINDT, R.N.. Oocyte: in vitro maturation. Reviews in Endocrine and Metabolic Disorders, v.3, p.5$12,2004$.

SOUZA, C. J. H., CAMPBELL, B. K., MCNEILLY, A. S., BAIRD, D. T. Effect of bone morphogenetic protein 2 (BMP2) on oestradiol and inhibin A production by sheep granulosa cells, and localization of BMP receptors in the ovary by immunohistochemistry. Reproduction, v. 123, p. 363-369, 2002.

SOUZA, C. J., CAMPBELl, B. K., MCNEILlY, A. S., BAIRD, D. T. Bone morphogenetic proteins and folliculogenesis: lessons from the Booroola mutation. Reproduction, v. 61, p.361-370, 2003.

SU, Y.Q., WIGGLESWORTH, K., PENDOLA, F.L., O’BRIEN, M.J., EPPIG, J.J. Mitogen activated protein kinase activity in cumuluscells is essential for gonadotropininduced oocyte meiotic resumption and cumulusexpansion in the mouse. Endocrinology, v. 143, p. 2221-2232, 2002.

SUGIURA, K., PENDOLA, F., EPPIG, J. Oocyte control of metabolic cooperativity between oocytes and companion granulose cells: Energy metabolism. Developmental Biology, v. 279, p. 20-30, 2005.

SUGIURA, K., SU, Y.Q., EPPIG, J.J. Targeted Suppression of Has2 mRNA in Mouse Cumulus Cell-Oocyte Complexes by Adenovirus-Mediated Short-Hairpin RNA Expression. Molecular Reproduction and Development, v.76, p. 537-547, 2009.

SUTTON, M. L., GILCHRIST, R. B., THOMPSON, J. G. Effects of in-vivo and in-vitro environments on the metabolism of the cumulus-oocyte complex and its influence on oocyte developmental capacity. Human Reproduction Update, v. 9, p. 35-48, 2003. 
TANGHE, S., VAN SOOM, A., NAUWYNCK, H., CORYN, M., DE KRUIFA. Minireview: functions of the cumulusoophorus during oocyte maturation, ovulation, and fertilization. Molecular Reproduction and Development, v. 61, p. 414-424, 2002.

TESFAYE, D., GHANEM, N., CARTER, F., FAIR, T. Gene expression profile of cumulus cells derived from cumulus-oocyte complexes matured either in vivo or in vitro. Reproduction, Fertility and Development, v. 21, p. 451-461, 2009.

VALLE, E. R., DODE, M. A. N. Efeito do tempo e da temperatura entre a coleta e a centrifugação, na concentração de progesterona do soro e plasma de vacas Nelore. Pesquisa Agropecuária Brasileira, v. 26, p. 479-485, 1991.

VAN DER HURK, R., ZHAO, J. Formation of mammalian oocytes and their growth, differentiation and maturation within ovarian follicles. Theriogenology, v. 63, p. 1717$1751,2005$.

VAN TOL, H.T., VAN EIJK, M.J., MUMMERY, C.L., VAN DEN HURK, R., BEVERS, M.M. Influence of FSH and hCG on the resumption of meiosis of bovine oocytes surrounded by cumulus cells connected to membrane granulosa. Molecular Reproduction and Development, 45: 218-224, 1996.

VANDERHYDEN, B.C. Oocyte-secreted factors regulate granulosa cell steroidogenesis. Zygote, v.4, p.317-321, 1996.

VANDERHYDEN, B.C., TELFER, E.E., EPPIG, J.J. Mouse oocytes promote proliferation of granulosa cells from preantral and antral follicles in vitro. Biology of Reproduction, v. 46, p. 1196-1204, 1992.

VASKIVUO, T.E., TAPANAINEN, J.S. Apoptosis in the human ovary. Reproductive BioMedicine Online, v. 6, p. 24-35, 2003.

VITT, U. A., HSUEH, A. J. Stage-dependent role of growth differentiation factor-9 in ovarian follicle development. Molecular and Cellular Endocrinology, v. 183, p. 171$177,2001$. 
VITT, U. A., MAZERBOURG, S., KLEIN, C., HSUEH, A. J. Bone morphogenetic protein receptor type II is a receptor for growth differentiation factor-9. Biology of Reproduction, v. 67, p. 473-480, 2002.

VITT, U. A., McGEE, E. A., HAYASHI, M., HSUEH, A. J. In vivo treatment with GDF9 stimulates primordial and primary follicle progression and theca cell marker CYP17in ovaries of immature rats. Endocrinology, v. 141, p. 3814-3820, 2000 b.

VITT, U.A., HAYASHI, M., KLEIN, C., HSUEH, A.J.W. Growth differentiation factor9 stimulates proliferation but suppresses the follicle- stimulating hormone-induced differentiation of cultured granulosa cells from small antral and preovulatory rat follicles. Biology of Reproduction, v. 62, p. 370-377, 2000a.

WATSON, A.J., DE SOUSA, P., CAVENEY, A., BARCROFT, L.C., NATALE, D., URQUHART, J., WESTHUSIN, M.E. Impact of Bovine Oocyte Maturation Media on Oocyte Transcript Levels, Blastocyst Development, Cell Number, and Apoptosis. Biology of reproduction, v.62, p.355-364, 2000.

WEBB, R., NICHOLAS, B., GONG, J. G., CAMPBELL, B. K., GUTIERREZ, C. G., GARVERICK, H. A., ARMSTRONG, D. G. Mechanism regulating follicular development and selection of the dominant follicle. Reproduction in Domestic Ruminants, v. 61, p. 71-90, 2003.

WELT, C.K., SCHNEYER, A.L. Differential regulation of inhibin B and inhibin a by follicle-stimulating hormone and local growth factors in human granulosa cells from small antral follicles. Journal of Clinical Endocrinology e Metabolism. v.86, p.330336, 2001.

WELT, C.K., ADAMS, J.M., SLUSS, P.M., HALL, J.E. Inhibin A and inhibin B responses to gonadotropin withdrawal depends on stage of follicle development. Journal of Clinical Endocrinology e Metabolism, v. 84, p. 2163-2169, 1999.

WILSON, T., WU, X.Y., JUENGEL, J.L., ROSS, I.K., LUMSDEN, J.M., LORD, E.A., DODDS, K.G., WALLING, G.A., MCEWAN, J.C., O’CONNELL, A.R., McNATTY, K.P., MONTGOMERY, G.W. Highly prolific Booroola sheep have a mutation in the 
intracellular kinase domain of bone morphogenetic protein IB receptor (ALK-6) that is expressed in both oocytes and granulosa cells. Biology of Reproduction, v. 64, p. 1225$1235,2001$.

WRENZYCKI, C., HERRMANN, D., LUCAS-HAHN, A., KORSAWE, K., LEMME, E., NIEMANN, H. Messenger RNA expression patterns in bovine embryos derived from in vitro procedures and their implications for development. Reproduction, Fertility and Development, v. 17, p. 23-35, 2005.

WU, X., MATZUK, M. M. GDF-9 and BMP-15: oocyte organizers. Reviews in Endocrine e Metabolic Disorders, v. 3, p. 27-32, 2002.

YEO, C., GILCHRIST, R.., THOMPSON, J., LANE, M. Exogenous growth differentiation factor 9 in oocyte maturation media enhances subsequent embryo development and fetal viability in mice. Human Reproduction, v. 23, n.1 p. 67-73, 2009.

YING, Y., LIU, X-M., MARBLE, A., LAWSON, K.A., ZHAO, G-Q. Requirement of BMP8b for the generation of primordial germ cells in the mouse. Molecular Endocrinology, v.14, p.1053-1063, 2000.

YOSHINO, O., MCMAHON, H. E., SHARMA, S., SHIMASAKI, S. A unique preovulatory expression pattern plays a key role in the physiological functions of BMP15 in the mouse. Proceedings of the National Academy of Sciences, v. 103, n. 28, p. 10678-10683, 2006.

ZHU, Y., HANNA, R.N., SCHAAF, M.J., SPAINK, H.P., THOMAS, P. Candidates for membrane progestin receptors-Past approaches and future challenges. Comparative Biochemistry and Physiology - Part C: Toxicology Pharmacology, v. 148, p. 381-389, 2008 .

ZUELKE, K.A., BRACKETT, B.G. Luteinizing hormone-enhanced in vitro maturation of bovine oocytes with and without protein suplementation. Biology of Reproduction, v. 43, p.784-787, 1990. 